\title{
GEOLOGY AND HYDROLOGY OF THE EDWARDS AQUIFER IN THE SAN ANTONIO AREA, TEXAS
}

\author{
U.S. GEOLOGICAL SURVEY
}

Water-Resources Investigations Report 95-4186

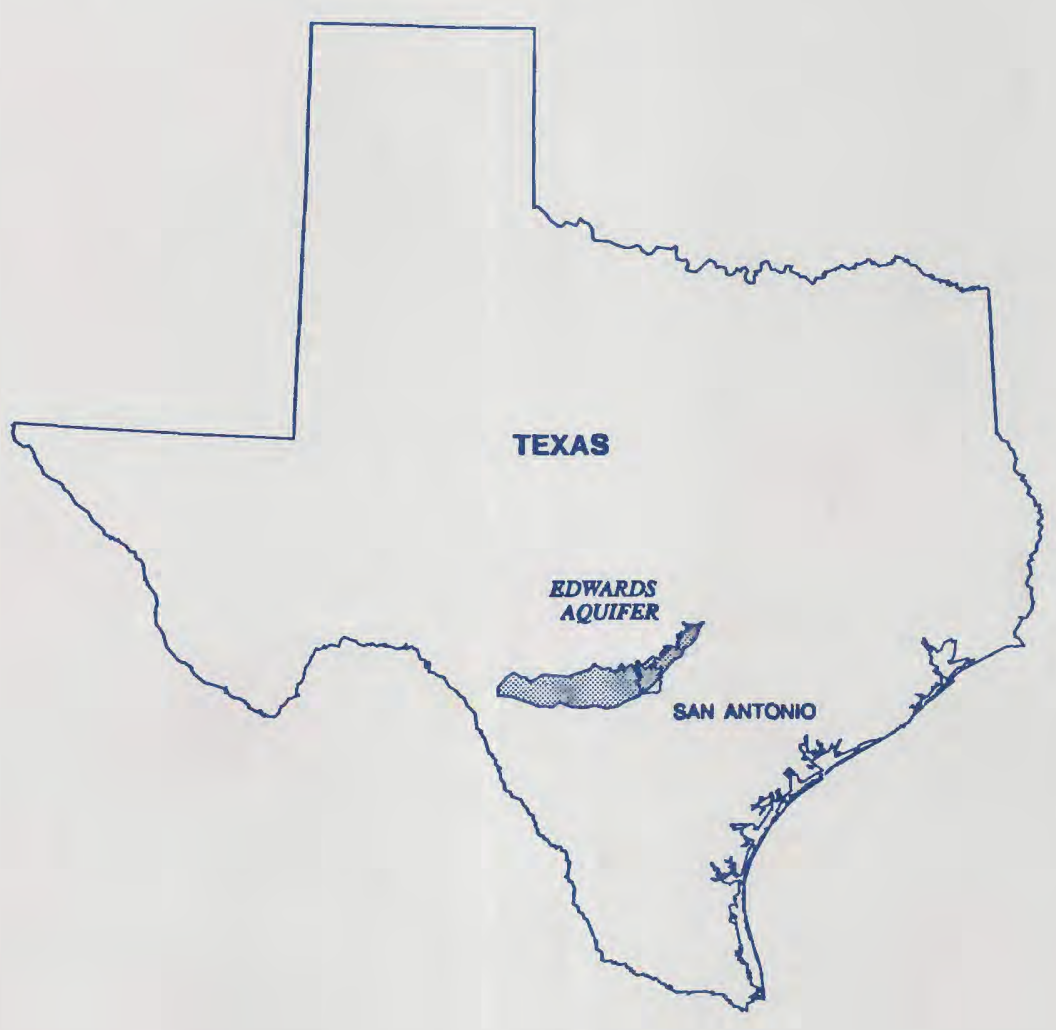




$$
\text { c }
$$




\section{GEOLOGY AND HYDROLOGY OF THE EDWARDS AQUIFER IN THE SAN ANTONIO AREA, TEXAS}

By Robert W. Maclay

U.S. GEOLOGICAL SURVEY

Water-Resources Investigations Report 95-4186

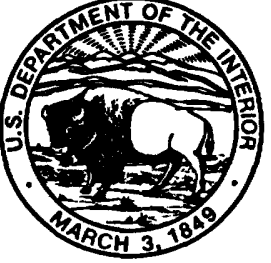

Prepared in cooperation with the 


\section{U.S. DEPARTMENT OF THE INTERIOR \\ BRUCE BABBITT, Secretary \\ U.S. GEOLOGICAL SURVEY \\ Gordon P. Eaton, Director}

Any use of trade, product, or firm names is for descriptive purposes only and does nct imply endorsement by the U.S. Government.

For additional information write to:

District Chief

U.S. Geological Survey

8011 Cameron Rd.

Austin, TX 78754-3898
Copies of this report can be purchased from:

U.S. Geological Survey

Earth Science Information Center

Open-File Reports Section

Box 25286, Mail Stop 517

Denver Federal Center

Denver, CO 80225-0046 


\section{CONTENTS}

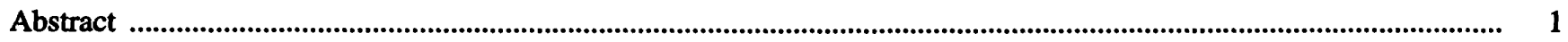

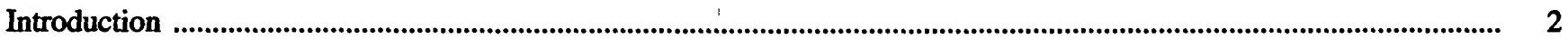

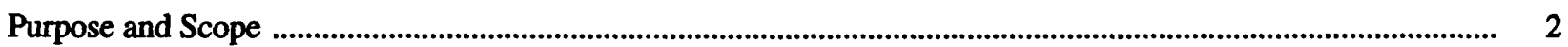

Location and Physiographic Setting ........................................................................................................................ 3

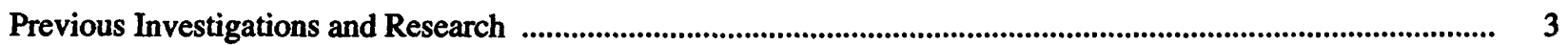

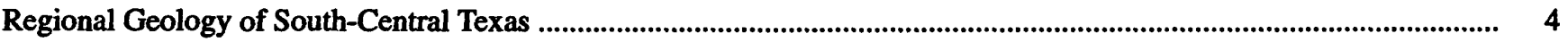

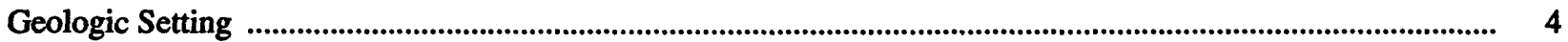

Depositional Provinces ................................................................................................................................................ 6

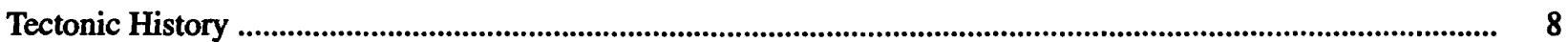

Major Structural Elements ........................................................................................................................................... 8

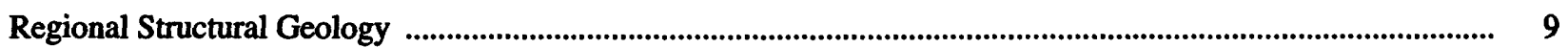

Structure of the Edwards Plateau ................................................................................................................. 9

Structure of the Balcones Fault Zone ........................................................................................................ 9

Structure of the Gulf Coastal Plain .................................................................................................................... 12

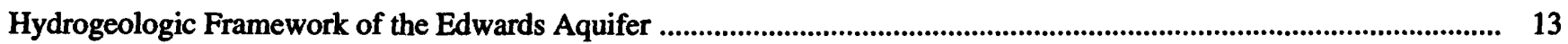

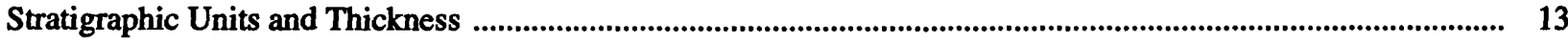

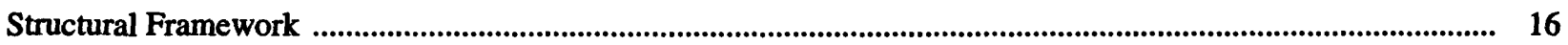

Development and Distribution of Porosity and Permeability ........................................................................ 16

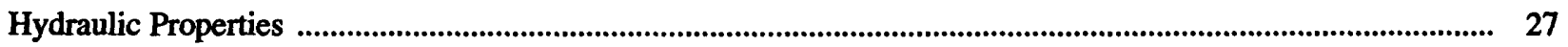

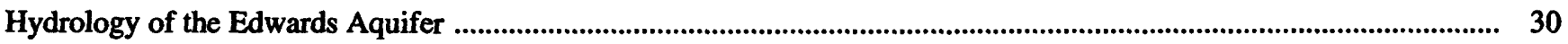

Climate, Precipitation and Effects, and Evapotranspiration ............................................................................ 30

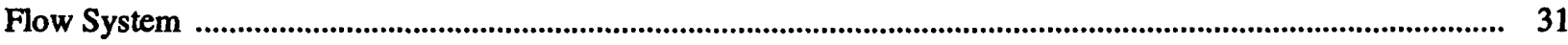

Regional Circulation Patterns ..................................................................................................... 31

Geologic Controls on Local Ground-Water Flow ............................................................................................ 32

Flow and Storage Concepts Based on Computer Simulation ................................................................. 34

Flow and Storage Units ....................................................................................................................... 34

Inflow and Outflow at Aquifer Boundaries ............................................................................ 37

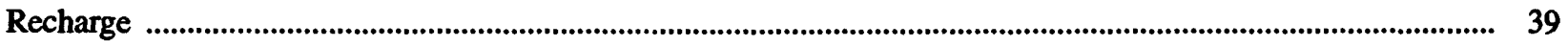

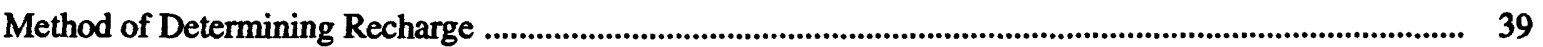

Unmeasured Inflow ................................................................................................................................................. 39

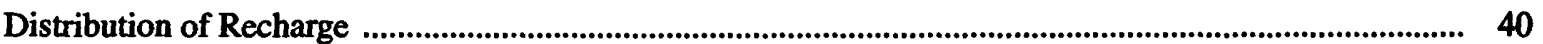

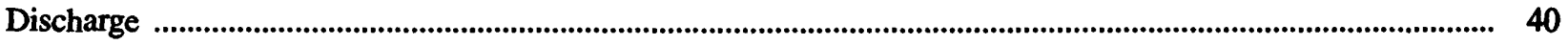

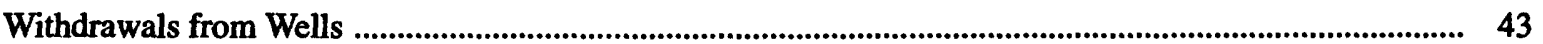

Springs and Seeps ......................................................................................................................................... 43

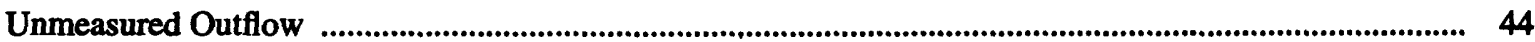

Ground-Water Storage and Water Levels ....................................................................................................................4. 44

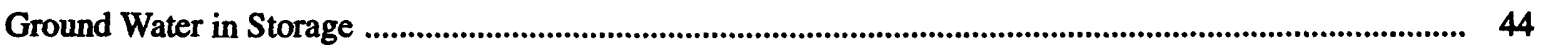

Fluctuations of Ground-Water Levels .................................................................................................. 48

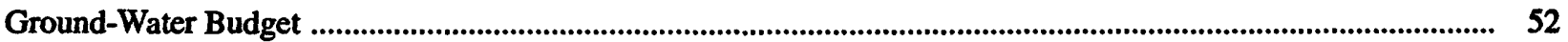

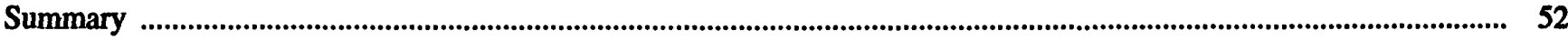

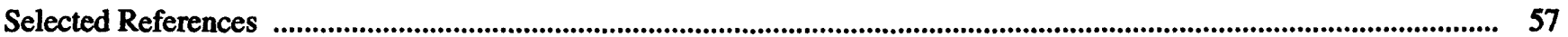




\section{PLATES}

[Plates are in pocket]

1-12. Maps showing:

1. Location and hydrologic features of the San Antonio area, Texas

2. Generalized geologic section through the central part of the San Antonio area, Texas

3. Surficial geology of the San Antonio area, Texas

4. Major faults of the Balcones fault zone and relation to the Edwards aquifer in the San Antonio area, Texas

5. Generalized structural surface of the top of the Edwards aquifer in the San Antonio area, Texas

6. Locatiori of hydrogeologic sections through the Edwards aquifer in the San Antonio area, Texas

7. Transmissivity of the Edwards aquifer in the San Antonio area, Texas, based on flow-model analysis

8. Anisotropy ratios derived from flow-model analysis of the Edwards aquifer in the San Antonio area, Texas

9. Potentiometric surface and regional ground-water-flow pattern in the Edwards aquifer, winter of 1973, in the San Antonio area, Texas

10. Storage and flow units of the Edwards aquifer in the San Antonio area, Texas

11. Drainage basins, streamflow-gaging stations, and precipitation stations associated with the recharge area of the Edwards aquifer in the San Antonio area, Texas

12. Location of pumping centers representing areas where moderate to large volumes of water are withdrawn from the Edwards aquifer in the San Antonio area, Texas

\section{FIGURES}

1. Tectonic map of Texas with emphasis on south-central Texas

2-4. Maps showing:

2. Depositional provinces of the Edwards Limestone and equivalent rocks

3. Structural surface of the top of the Lower Cretaceous rocks and major structural features of south-central Texas

4. Major lineaments and long fracture zones in the San Antonio area, Texas, and vicinity

5. Regional stratigraphic section of rocks forming the Edwards aquifer from the Maverick basin to the San Marcos platform in the San Antonio area, Texas

6-9. Hydrogeologic sections:

6. $A-A^{\prime}$ through the Edwards aquifer in Comal County, Texas

7. $B-B^{\prime}$ through the Edwards aquifer in Bexar County, Texas

8. $C-C^{\prime}$ through the Edwards aquifer in Medina County, Texas

9. $D-D^{\prime}$ through the Edwards aquifer in Uvalde County, Texas

10. Map showing water types and generalized late diagenetic processes presently affecting porosity and permeability in the Edwards aquifer in the San Antonio area, Texas

11. Chart showing relative permeability of hydrostratigraphic zones within and adjacent to the

Edwards aquifer in the San Antonio area, Texas

12. Diagram showing geophysical logs and hydrostratigraphic zones of the Edwards aquifer within the San Marcos platform, based on data from the Castle Hills test hole in San Antonio, Texas

13. Diagram showing geophysical logs and stratigraphy of the Edwards aquifer within the Maverick basin, based on data from the Uvalde test hole, 6 miles northwest of Uvalde, Texas

14. Schematic diagrams showing effect of fault displacements on ground-water flow in the Edwards aquifer in the San Antonio area, Texas

Map showing vertical displacement along barrier faults in the Edwards aquifer in the San Antonio

area, Texas

16. Map showing model-determined flow vectors for the Edwards aquifer in the San Antonio area, Texas

17. Graphs showing annual recharge for recharge basins of the Edwards aquifer in the San Antonio area, Texas, 1934-88

18. Graph showing relation among annnal recharge, annual discharge, and average annual recharge and discharge for the Edwards aquifer in the San Antonio area, Texas, 1934-88 discharge for the Edwards aquifer in the San Antonio area, Texas, $1934-88$ 
19. Hydrographs showing discharge from Hueco, Comal, and San Marcos Springs in the San Antonio area, Texas

20. Graph showing relation between storage in the Edwards aquifer and ground-water levels at an observation well (AY-68-37-203) in San Antonio, Texas

21. Hydrographs showing annual maximum and minimum water levels in selected wells in the Edwards aquifer in the San Antonio area, Texas, 1934-88

22. Composite hydrograph showing ground-water levels from several wells in San Antonio, Texas ........................ 50

23. Graphs showing relation of water-level fluctuations in wells in the San Antonio area, Texas, to barometric-pressure fluctuations

24. Graphs showing water-level fluctuations resulting from pumping in San Antonio, Texas

25. Schematic diagram showing generalized ground-water budget for the Edwards aquifer in the San Antonio area, Texas: (A) Variation of water-budget components during 1979-88; and (B) Waterbudget components during a drought year and a wet year

\section{TABLES}

1. Summary and description of the geologic units in the depositional provinces of the San Antonio area, Texas

2. Depositional environments, matrices, diagenesis, and porosities of typical lithofacies in the

Edwards aquifer in the San Antonio area, Texas

3. Geologic factors affecting the development of porosity and permeability in the Edwards aquifer in the San Antonio area, Texas

4. Porosity and permeability features of the hydrostratigraphic zones in the Edwards aquifer withinin the San Marcos platform in the San Antonio area, Texas

5. Major storage units of the Edwards aquifer in the San Antonio area, Texas 38

6. Major flow units of the Edwards aquifer in the San Antonio area, Texas 38

\section{CONVERSION FACTORS AND VERTICAL DATUM}

\begin{tabular}{|c|c|c|}
\hline Multiply & By & To obtain \\
\hline acre-foot (acre-ft) & 0.001233 & cubic hectometer \\
\hline acre-foot per foot (acre-ft/ft) & 0.0041 & cubic hectometer per meter \\
\hline acre-foot per year (acre-ft/yr) & 0.001233 & cubic hectometer per year \\
\hline barrel per day (bbl/d) & 158.97 & liter per day \\
\hline cubic foot $\left(\mathrm{ft}^{3}\right)$ & 0.02832 & cubic meter \\
\hline cubic foot per second $\left(\mathrm{ft}^{3} / \mathrm{s}\right)$ & 0.02832 & cubic meter per second \\
\hline foot $(f t)$ & 0.3048 & meter \\
\hline foot per mile (ft/mi) & 1.89 & meter per kilometer \\
\hline foot squared per day $\left(\mathrm{ft}^{2} / \mathrm{d}\right)$ & 0.09290 & meter squared per day \\
\hline foot squared per second $\left(\mathrm{ft}^{2} / \mathrm{s}\right)$ & 0.09290 & meter squared per second \\
\hline gallon per minute (gal/min) & 0.06308 & liter per second \\
\hline gallon per minute per foot $[(\mathrm{gal} / \mathrm{min}) / \mathrm{ft}]$ & 0.2070 & liter per second per meter \\
\hline inch (in.) & 25.4 & millimeter \\
\hline inch per year (in/yr) & 25.4 & millimeter per year \\
\hline mile (mi) & 1.609 & kilometer \\
\hline million gallons per day (Mgal/d) & 0.04381 & cubic meter per second \\
\hline square mile $\left(\mathrm{mi}^{2}\right)$ & 2.590 & square kilometer \\
\hline deoree Fahrenheit ( $\left.{ }^{\circ} \mathrm{F}\right)$ & $\begin{array}{l}\text { Temperature } \\
\left({ }^{\circ}-39\right) \times 11\end{array}$ & deoree Celsins \\
\hline
\end{tabular}

Sea level: In this report, "sea level" refers to the National Geodetic Vertical Datum of 1929 -a geodetic datum derived from a general adjustment of the first-order level nets of the United States and Canada, formerly called Sea Level Datum of 1929. 



\title{
Geology and Hydrology of the Edwards Aquifer in the San Antonio Area, Texas
}

\author{
By Robert W. Maclay
}

\section{Abstract}

The Edwards aquifer, which is the sole source of water for the city of San Antonio, is one of the most permeable and productive carbonate aquifers in the United States. The aquifer is composed of extensively faulted, fractured, and cavernous limestone and dolomite of Early Cretaceous age lying within the Balcones fault zone-a series of normal en echelon strike faults that separate the Edwards Plateau from the Gulf Coastal Plain in south Texas. Along segments of some faults, the entire thickness of the aquifer is displaced vertically, and these faults then act as barriers to downdip ground-water flow.

The large porosity and exceptional permeability of the unconfined part of the Edwards aquifer result from the dissolution of limestone by circulating ground water and development of a cavernous network along fractures. The large porosity and permeability of the freshwater part of the confined Edwards aquifer result primarily from dedolomitization. The small permeability of the saline-water part of the confined aquifer is caused by the limited interconnection between the pores in the rock matrix and by the lack of substantial dissolution along fractures.

The large transmissivity of the Edwards aquifer is indicated by the hundreds of highyielding wells, small hydraulic gradients, and large spring discharges. The determined transmissivity throughout most of the confined freshwater aquifer ranges from 430,000 to $2,200,000$ feet squared per day; the determined transmissivity of the unconfined aquifer generally is less than 430,000 feet squared per day. Faulting causes the aquifer to be highly anisotropic, and simulation indicates anisotropy ratios ranging from $0.0: 1$ to $1: 1$.
The ground-water-flow system of the Edwards aquifer includes several components. These include a catchment area on the Edwards Plateau where the unconfined aquifer receives direct recharge, an area of confining beds crossed by streams draining the Edwards Plateau, a major recharge area within the Balcones fault zone where streams lose flow directly into the unconfined Edwards aquifer, and the confined Edwards aquifer that consists of the freshwater and salinewater zones.

Water entering the Edwards aquifer in the Balcones fault zone moves downdip in a generally southeasterly direction into the confined parts of the aquifer. In the confined aquifer, flow is toward the east and northeast under low hydraulic gradients through fractured, highly transmissive limestone and ultimately discharges at large springs and wells. All of the base flow and some of the storm runoff of streams crossing the recharge area infiltrates to the unconfined aquifer. On the basis of streamflow losses, the average annual recharge for 1934-88 was 635,500 acre-feet.

Freshwater discharges from the Edwards aquifer primarily from wells, springs, and seeps. Beginning in 1968, annual discharge from the aquifer has consistently exceeded average annual recharge largely because of a doubling of well pumpage. However, total springflow also increased because of greater-than-average recharge during most years since the late 1960's.

The total volume of circulating freshwater in the Edwards aquifer is about 45 million acrefeet. Long-term hydrographs at San Antonio indicate no net decline in ground-water levels during 1911-87; thus, there was no net loss of water from storage in the freshwater zone of the Edwards aquifer during that long-term period, assuming the 
San Antonio hydrograph represents the entire aquifer. However, short-term changes in water levels result largely from the variability of precipitation as indicated by severe declines during the drought of the late 1940's to middle 1950's and by rises to record highs during the abnormally wet years in the 1970's and 1980's.

The principal components of the groundwater budget (recharge, springflow, and pumpage) have varied greatly over 55 years (1934-88) of pertinent hydrologic records. Annual recharge varied from about 44,000 to 2,000,000 acre-feet. Annual springflow varied from about 70,000 acrefeet to about 580,000 acre-feet. Pumpage increased from about 100,000 acre-feet annually in the early 1930's to more than 500,000 acre-feet annually during some years in the 1980's. However, the average annual recharge of 635,500 acrefeet is about equal to the sum of the average annual springflow (359,500 acre-feet) and average annual pumpage $(273,000$ acre-feet), indicating no longterm decrease in ground-water storage because of springflow and pumpage.

\section{INTRODUCTION}

The Edwards aquifer is one of the most permeable and productive carbonate aquifers in the United States and has been designated as a "sole source" water supply for the city of San Antonio by the U.S. Environmental Protection Agency. Demands on the aquifer are accelerating rapidly because of the greater need for water for a growing urban population and extensive agricultural irrigation. Total pumpage from the Edwards aquifer was 539,900 acre-ft during 1988, a year of less-than-average precipitation. This quantity is about 85 percent of the average annual recharge.

The Edwards aquifer consists of the Georgetown Formation and the Edwards Limestone or their stratigraphic equivalents. These formations are regionally extensive carbonate rocks that crop out within the Edwards Plateau and the Balcones fault zone and underlie the Gulf Coastal Plain (pl. 1). The Edwards aquifer is bounded on the north by the northern limit of the formations in the recharge area of the faulted outcrop, on the west and east by ground-water divides, and on the south by the saline-water zone of the Edwards aquifer. The Edwards aquifer is about $180 \mathrm{mi}$ long from west to east and ranges from 5 to $40 \mathrm{mi}$ wide from north to south.

The interface (surface) between the freshwater zone, where dissolved-solids concentrations are less than $1,000 \mathrm{mg} / \mathrm{L}$ (milligrams per liter), and the salinewater zone, where dissolved-solids concentrations are $1,000 \mathrm{mg} / \mathrm{L}$ or greater, is defined for this report as the downdip limit of the freshwater zone of the Edwards aquifer (pl. 1). The line on land surface directly overlying the intersection of the downdip limit of the freshwater zone with the top of the aquifer is known locally as the "bad-water" line. In addition to the freshwater and saline-water zones, the "transition zone," in this report, refers to subzones of the freshwater and salinewater zones within about $1,000 \mathrm{ft}$ on either side of the downdip limit of the freshwater zone.

This report is the culmination of research studies of the Edwards aquifer by the U.S. Geological Survey (USGS) in cooperation with the San Antonio Water System. Research began in 1970 with the purpose of developing a more detailed understanding of the hydrogeologic framework of the Edwards aquifer and its flow system.

The San Antonio area, as defined by Petitt and George (1956, p. 3), includes parts of Kinney, Uvalde, Medina, Bexar, Comal, and Hays Counties that lie within and adjacent to the Balcones fault zone. This area contains the most productive and transmissive part of the Edwards aquifer. It is the area of investigative interest of the San Antonio Water System. The study area expands on the San Antonio area to include the catchment area of the Edwards Plateau and parts of the Hill Country.

\section{Purpose and Scope}

This report describes (1) the tectonic and sedimentational processes that determined the physical properties of the geologic formations in south-central Texas, (2) the resulting hydrogeologic framework and hydraulic properties of the Edwards aquifer in the San Antonio area, and (3) the hydrology of the Edwards aquifer, including the regional ground-water-flow system, geological controls on local ground-water flow, and rates of recharge to and discharge from the aquifer. The report focuses on the geohydrology of the Edwards aquifer in the San Antonio area. However, the report contains regional information on south-central Texas to aid in understanding the features of the local setting. 


\section{Location and Physiographic Setting}

South-central Texas, as used here, includes the southern part of the Edwards Plateau, the Balcones fault zone, and the northern part of the Gulf Coastal Plain south of the Edwards Plateau, or upper Gulf Coastal Plain. The San Antonio area lies primarily within the Balcones fault zone; however, the catchment area (watersheds) of major streams recharging the Edwards aquifer lies within the Edwards Plateau.

The Edwards Plateau is an extensive uplands area that ranges in altitude from about $1,500 \mathrm{ft}$ to more than $2,300 \mathrm{ft}$ above sea level. It consists of two subareas: a limestone-capped high plateau of low local relief and a lower dissected plateau of moderate relief that is underlain mostly by marl, shale, and limestone. The high plateau is serrated along its margins by reentrant valleys cut by headward-eroding streams. Many contact springs within the reentrant valleys sustain the flow of the nearby streams. Caves occur along escarpments and are hundreds of feet above the level of present-day drainage. The lower dissected plateau contains many hills and buttes and locally is known as the "Hill Country." The Hill Country is noted for beautiful streams of clear water flowing along cypress-lined channels.

The Balcones escarpment is a prominent topographic feature of variable relief that separates the Edwards Plateau from the Gulf Coastal Plain. It occurs as segments within the Balcones fault zone and commonly rises from about $100 \mathrm{ft}$ to several hundreds of feet above the adjacent lowland. Large alluvial fans extend southward from some individual segments. The location of and relief along the escarpment is controlled by sets of en echelon faults within the fault zone.

The Gulf Coastal Plain lies south of the Balcones escarpment. It is a gently gulfward-sloping plain of low to moderate relief and is underlain by sands and clays of Tertiary age, except for an area within the Balcones fault zone where shale, limestone, and clay of Cretaceous age are exposed.

The Balcones fault zone includes the southern limit of the Edwards Plateau, the Balcones escarpment, and the northern limit of the Gulf Coastal Plain. It is a belt crossed by many northeast-trending parallel faults that, in some places, control the drainage configuration and the location of minor escarpments. Much of the Balcones fault zone in Uvalde, Medina, and Bexar Counties is covered by extensive flat alluvial fans and terraces. The higher terraces are greatly dissected, and little of their original surfaces and extent remain.

Caves and sinkholes are common where limestone of Cretaceous age is exposed in the elevated areas immediately north of the Balcones escarpment, such as in northern Bexar, northwestern Comal, and Hays Counties. Sinkholes currently are not forming; however, existing sinkholes probably are interconnected by solution channels formed by the ancestral drainage system.

\section{Previous Investigations and Research}

Prior to 1970, several different types of investigations of the San Antonio area were made. The concept of a northeastward movement of ground-water flow in the Edwards aquifer was presented by Sayre and Bennett (1942). Studies conducted by William F. Guyton and Associates (1955) provided methods for determining recharge to the Edwards aquifer. Extensive data on water levels, surface geology, and water quality were collected by the USGS prior to 1970 . General hydrologic studies of the Edwards aquifer were conducted by Petitt and George (1956) and Garza (1962, 1966). George (1952), Arnow (1959), Holt (1959), Bennett and Sayre (1962), Welder and Reeves (1962), and DeCook (1963) made studies assessing the ground-water resources of various counties composing the San Antonio area.

Research by the USGS during 1970-88 included four phases. The initial phase (1970-76) was concerned primarily with data collection and assimilation of knowledge on the geology, hydrology, and hydrochemistry of the Edwards aquifer. The regional synthesis of the stratigraphy of the Edwards Limestone in southern Texas by Rose (1972) provided a stratigraphic framework for the investigation; this was particularly important for the interpretation of vertical and lateral distribution of porosity and permeability in the aquifer. A program of test-hole drilling and geophysical logging of available holes penetrating the Edwards aquifer in the San Antonio area was initiated. This program resulted in coring 8 test holes and collecting borehole geophysical logs at more than 600 sites. The cored test holes and the geophysical logs provided the data base to evaluate the lateral continuity and hydrogeologic characteristics of the Edwards aquifer in accordance with the stratigraphy developed by Rose (1972).

Cores from test holes in the freshwater and saline-water zones of the Edwards aquifer were 
examined using techniques applicable for carbonate rocks. These included the megascopic and microscopic examinations of rock cores to obtain data for interpretation of diagenesis (changes in sediment occurring under conditions of pressure and temperature). Measurements of permeability, porosity, and formation factor were made for rocks from various stratigraphic units (Small and Maclay, 1982). Geophysical logging included the collection of radiation, electrical, and caliper logs (Maclay and others, 1981). Cross-plotting techniques were used to determine primary and secondary porosity, fracturing, and mineralogy. Fluid-flow and tracer tests were used to determine flow velocity and porosity. Hydrochemical studies included the collection and analysis of water samples from the Edwards aquifer to determine saturation indices, isotopic composition, and concentrations of inorganic constituents (Pearson and Rettman, 1976; Maclay, Rettman, and Small, 1980). The data were interpreted to develop or substantiate concepts of the rates and directions of ground-water flow in the aquifer.

The second phase of research (1976-82) was concerned primarily with the analysis of collected geologic, hydrologic, and hydrochemical data including the data collected during the first phase. Such analysis was used to develop concepts regarding the nature of the porous media in the Edwards aquifer and the internal and external boundary conditions of the aquifer. Many geologic cross sections and a structure contour map of the top of the Edwards aquifer were prepared (Small, 1986). The cross sections and map provided the basis for identifying the major faults. Regional potentiometric-surface maps were prepared and superimposed onto structural maps to help investigate the effect of faults on ground-water flow (Maclay and Small, 1983). Maps were prepared to indicate the areal distribution of hydrochemical facies and concentrations of principal ions in solution. These maps were used to help interpret the movement of ground water in the freshwater and saline-water zones. A progress report on the geology and hydrology of the Edwards aquifer in the San Antonio area was prepared at the completion of this phase (Maclay and Small, 1984).

The third phase of research (1982-86) was concerned with testing concepts relating to movement and storage of water in the Edwards aquifer. A groundwater-flow model developed by Trescott and others (1976) was modified to provide the capability of representing faults. It was used to simulate flow and storage in the aquifer. The simulations facilitated the investiga- tion of the effects of geologic structure and spatial variations of transmissivity, anisotropy, and storage coefficients in the aquifer (Maclay and Land, 1988).

The fourth phase of research (beginning in 1986) was concerned with the preparation of this report. The previous studies were reviewed, and additional information was collected on regional and local tectonic history. Research of the tectonic history of south-central Texas, particularly the Balcones fault zone, provided descriptions of major faults in the area and insights into the origin of the Edwards aquifer.

\section{REGIONAL GEOLOGY OF SOUTH- CENTRAL TEXAS}

\section{Geologic Setting}

Sedimentary and crystalline rocks that range in age from Precambrian to Holocene underlie southcentral Texas. These rocks are subdivided, for the purpose of this discussion, into three groups: (1) rocks of Precambrian age, (2) formations of Paleozoic age, and (3) formations of Mesozoic and Cenozoic age. Major unconformities separate the three rock groups. A generalized geologic section through the central part of the San Antonio area is shown in plate 2.

Structural features that have persisted for long periods of geologic time and have influenced the deposition of the Paleozoic through Cenozoic sedimentary rocks (pl. 2) are shown on the tectonic map of Texas with emphasis on south-central Texas (fig. 1). The role of these features is discussed in the later section on tectonic history.

Rocks of Precambrian age are not exposed in the San Antonio area; however, they are exposed in the Edwards Plateau in the Llano uplift (fig. 1). These rocks are the basement cratonic rocks that form the continental crust above the Earth's mantle. In the Llano uplift area, the Precambrian rocks consist of metasedimentary rocks intruded by granite (Barnes and others, 1972). These rocks are intensively faulted by highangle faults that trend generally northeastward and cut rocks of Precambrian and Paleozoic ages.

A major erosional unconformity, which can be identified in the Llano uplift (Barnes and others, 1972), separates formations of Paleozoic age from the underlying Precambrian rocks. The Paleozoic formations consist of hundreds of feet of sandstone, dolomite, limestone, siltstone, shale, and metamorphic rocks and constitute a foreland and Ouachita facies (Flawn and 


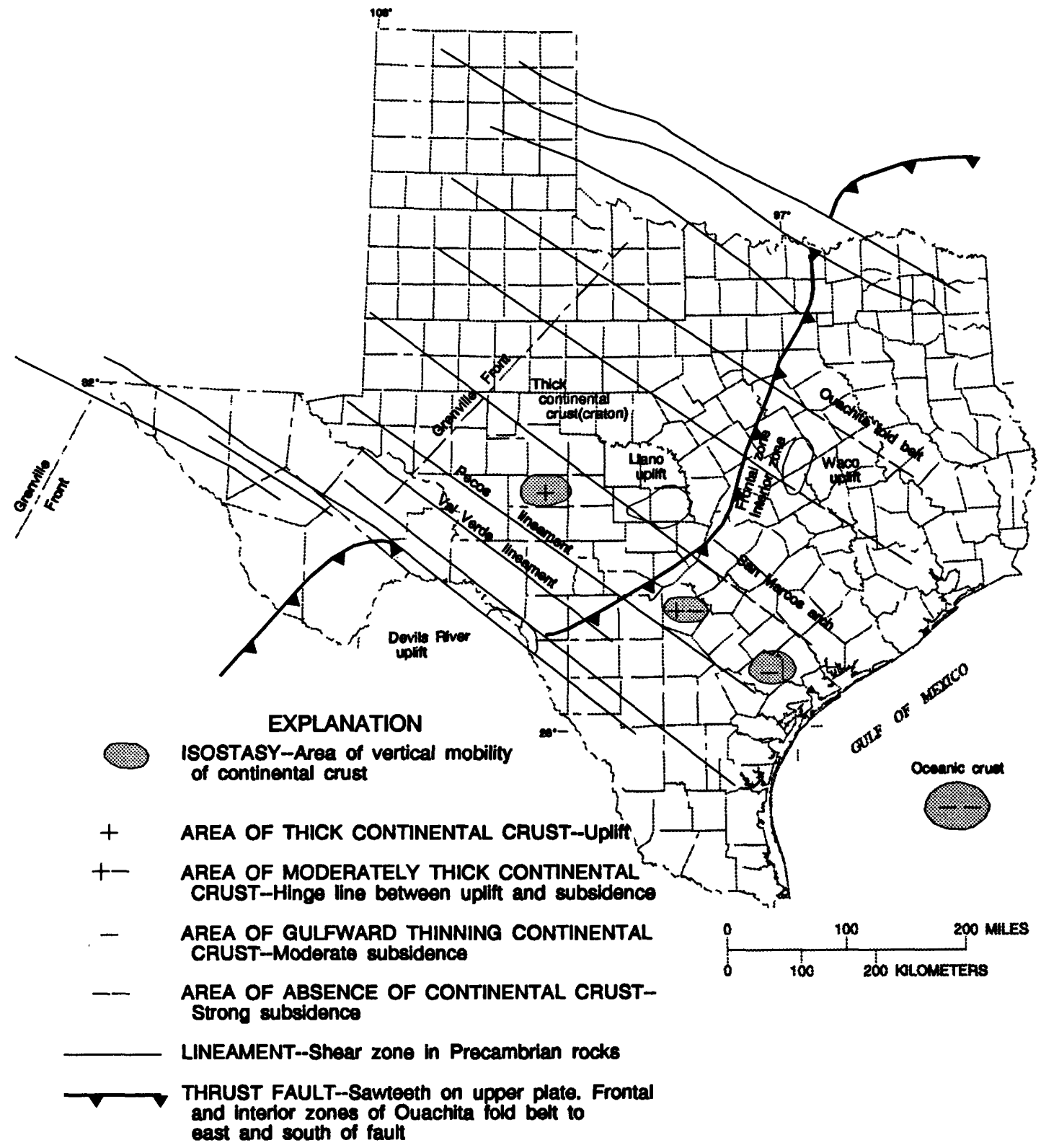

Figure 1. Tectonic map of Texas with emphasis on south-central Texas. (Modified from Muehlberger, 1965, and Bolden, 1983.) 
others, 1961). Thrust faulting throughout much of the Paleozoic section formed the Ouachita fold belt (fig. 1), which consists predominantly of slate, metashale, and metasandstone. In the San Antonio area, the Paleozoic rocks are present at depths of about 500 to $8,000 \mathrm{ft}$, and there is little information about them.

Formations of Mesozoic and Cenozoic age are extensively exposed in the San Antonio area (pl. 3), and these formations exhibit various depositional facies. In general, the major facies within the formations reflect the energy conditions of transgressions (encroaching) of seas onto the continental craton during Mesozoic time and regression (receding) of seas from the continental craton during Cenozoic time. Table 1 (at end of report) presents a summary and description of the geologic formations within each depositional province in the study area. Carbonate-rock descriptions are those of Dunham (1962).

The Mesozoic rocks contain near-shore facies, consisting of sediments deposited on tidal flats and sabkhas, and of offshore carbonate sediments that accumulated on a carbonate platform. Rocks overlying internal unconformities consist of shoreline sediments near the craton grading downdip (seaward) into subtidal carbonate rocks. Each unconformity within the Lower Cretaceous rocks represents an end of a cycle of sedimentation. Consequently, different depositional facies are superimposed locally. The Upper Cretaceous formations reflect more uniform depositional conditions when the seas inundated a vast region of the continental interior. Over most of the area, thick beds of deep-water marine clay and carbonate rocks were deposited. In addition, volcanic ash and bentonite commonly are present in the Upper Cretaceous rock sequence. The Mesozoic sedimentary rocks are intruded by igneous rock, mainly basalt, which commonly is altered to serpentine, especially in Uvalde County.

The Cenozoic deposits consist mostly of clastic sediments that accumulated near the shoreline of regressing continental seas. The deposits are mostly in the Gulf Coastal Plain and are derived from the erosion of the Edwards Plateau and other areas of north-central Texas. These deposits are cut by major faults that extend into the underlying Mesozoic rocks.

Late Cenozoic deposits consist of large alluvial fans that extend from the Balcones escarpment across the Balcones fault zone and into the Gulf Coastal Plain. These alluvial fans and associated terrace deposits are the results of intermittent uplifts of the Edwards Pla- teau. During and following an uplift, erosion occurred, and gravel and coarse sand were deposited by streams emerging from the Edwards Plateau and spreading out onto the Gulf Coastal Plain. As erosion continued and the uplift rate declined, finer sediments were deposited above the gravel and coarse sand.

\section{Depositional Provinces}

Four depositional provinces were formed in south-central Texas during Early Cretaceous timecentral Texas platform on the Edwards Plateau, Maverick basin, Devils River trend, and San Marcos platform. However, of these four provinces, three major provinces-Maverick basin, Devils River trend, and San Marcos platform-occupy most of the present-day areal extent of the Edwards aquifer in the San Antonio area, and these will be discussed briefly (fig. 2). Although energy conditions varied from time to time with advances and recessions of the epicontinental seas, the energy conditions associated with carbonate deposition were different for each province.

The Maverick basin was a site of deposition below the wave base where fine-grained, homogenous carbonate sediments accumulated in thick, massive deposits. These sediments consist predominantly of deep-basin, dense, homogeneous limey mudstone. Lagoonal evaporites and euxinic shale initially accumulated in the center of the Maverick basin and then spread laterally. Subtidal to supratidal, shallow-water limestone, dolomite, and evaporite accumulated to the north at the same time. The Maverick basin, which, as a basin of deposition, was between the Stuart City reef trend to the south and tidal flats or shallow water to the north and east (Smith, 1974), became an openmarine, deep-water embayment when a transgression breached the Stuart City reef. This transgression is marked by a basal conglomerate bed overlain by a pelagic mudstone. Rudist-talus grainstone developed on the limey mudstone during a marine regression. The Maverick basin became extinct when a later transgression inundated the Stuart City reef and deposited sediments of the Del Rio Clay on the grainstone.

The Devils River trend represents a shoal area that formed at the northern end of the Maverick basin under largely open, shallow-marine conditions. Sediment in the Devils River trend consists of marine and supratidal deposits in the lower part and reefal or interreefal deposits in the upper part. The reefs developed in a high-energy environment where wave action was 


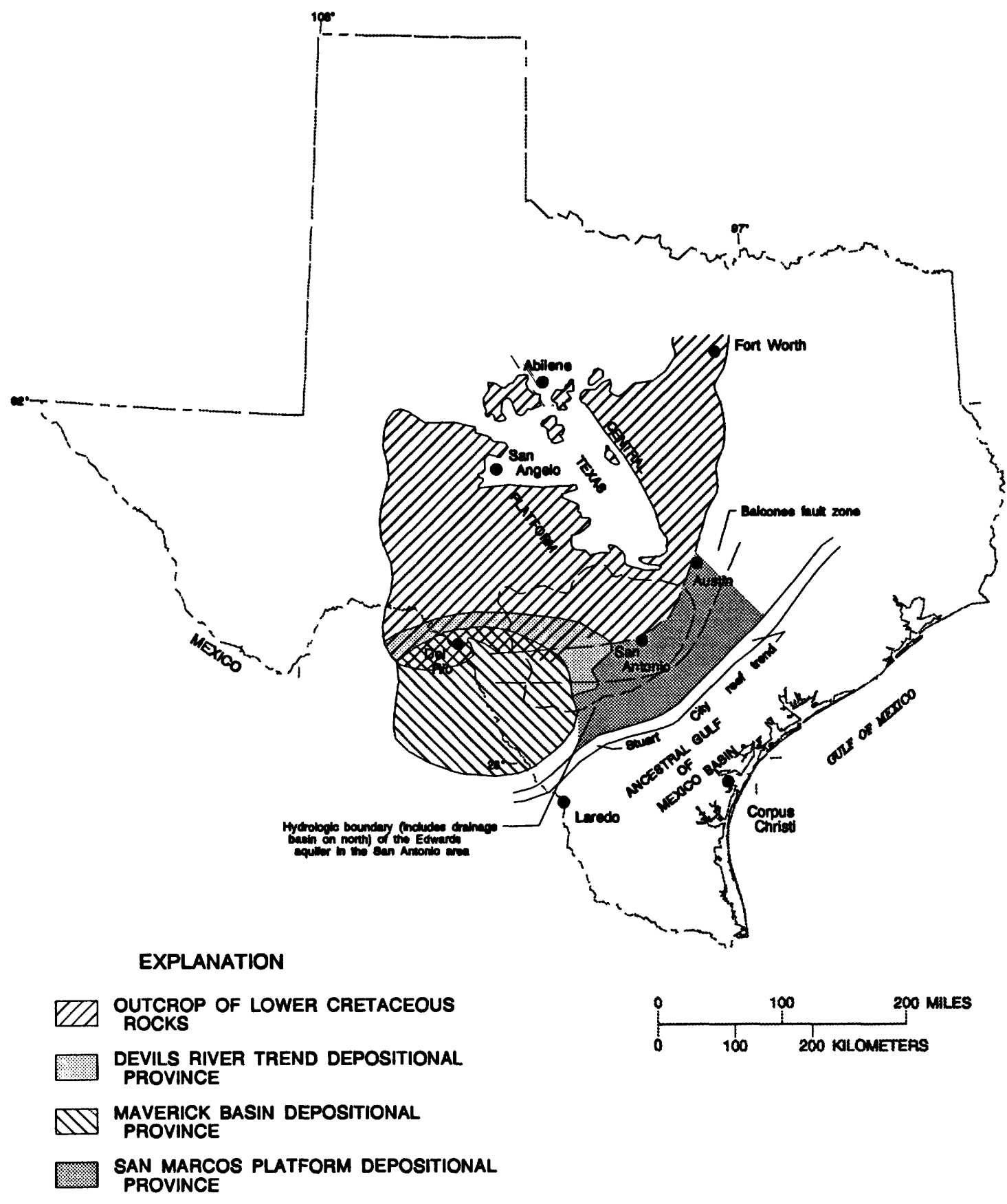

Figure 2. Depositional provinces of the Edwards Limestone and equivalent rocks. (Modified from Rose, 1972, and Maclay and Small, 1984.) 
strong. Rudist-coral reefs and associated reef talus, which were intermittently exposed by fluctuating sea level, accumulated on a base formed of sediments similar to those of the Maverick basin.

The San Marcos platform was an area of tidal flats, sabkhas, and subaerial erosion (Rose, 1972). During Early Cretaceous time, the ancestral Gulf of Mexico was a deep-water, fore-reef basin in which deposition occurred well below the wave base. The sediments on the San Marcos platform consist mostly of dolomite, dolomitic limestone, particularly mudstone, and wackestone (micrite). Locally they include collapse breccia, honeycombed structures, burrowed mudstone, and rudist-reef materials. The depositional environment varied through space and time from open marine to arid, hot, supratidal flats (Rose, 1972). Areally extensive, thin- to medium-bedded strata of pelleted and intraclastic micrites accumulated to a thickness of about $500 \mathrm{ft}$. Anhydrite or gypsum deposits accumulated in laterally continuous beds and isolated lenses within the micritic sediments. Deposition at the top of the Edwards Group was interrupted by a period of subaerial erosion and karstification (Rose, 1972). After this erosional period, the Edwards Group was deeply buried by marine, transgressive sediments during Late Cretaceous time.

\section{Tectonic History}

Interpretation of the tectonic history of southcentral Texas since Paleozoic time has been assisted by an accumulation of tectonic evidence along with knowledge of plate tectonics. Structural activity, including Cenozoic uplifts of the Edwards Plateau, Late Cretaceous wrench faulting in the Balcones fault zone, and Cenozoic extension faulting, can be explained logically by geologic principles of plate interaction. According to Horak (1985), plate tectonics provides the framework for the interpretation of the geological system.

Plate interactions are the major cause of stress that affects regional tectonic changes. Plate-interaction chronology provides a stress history, which is the basis for understanding how local structure has evolved. An important parameter of a regional stress-field analysis is the principal horizontal stress, as explained by Horak (1985). The principal horizontal stress determines the orientation of other components of the stress field.

When a particular structural feature is linked to a par- ticular stress field, its deformational history and its internal structure can be inferred.

Vertical crustal mobility is a response to a variety of tectonic processes including those driven by plate interactions. Marked variations in isostatic rates (uplift and subsidence) generally define tectonic episodes and changes in tectonic processes resulting from changes in plate interactions. In south-central Texas, broad vertical warping and sagging, rapid uplift or subsidence, and tectonic quiescence (stability) characterize the tectonic activity through geologic time. The most recent activity probably occurred during later Tertiary or perhaps Holocene time. The area of the Edwards Plateau and inland part of the Gulf Coastal Plain is a positive tectonic area (presently being uplifted), and the coastal part of the Gulf Coastal Plain is a negative tectonic area (presently sinking) (fig. 1).

The late Precambrian faults include major wrench faults that developed as a result of plate tectonics and extend into the crust of the Earth. These faults probably are aligned with major surface lineaments, which trend northwestward from the Gulf Coastal Plain into the continental craton (fig. 1). These faults have been active during different periods of tectonic activity, including the Holocene.

The early to middle Paleozoic faults are normal faults, which have a steep dip and displace early Paleozoic rocks. These faults trend northeastward and confine overlapping layers of late Paleozoic rocks. Faults of this age are exposed in the Llano uplift, but little is known about these faults in the Gulf Coastal Plain where they are deeply buried.

In the downdip part of the Gulf Coastal Plain, most faults are normal, active, and listric, and strike nearly parallel to the continental margin (Zoback and Zoback, 1980). Locally, strike-slip and thrust faults (evidence of compressional tectonics) are reported by Zoback and Zoback (1980) to be near the Balcones fault zone. The mixed style of faulting (combination of strike-slip, normal, and thrust) in the Balcones fault zone might result from two principal horizontal stresses being nearly equal in magnitude. Local variations in geology also could be a factor (Zoback and Zoback, 1980).

\section{Major Structural Eiements}

Three major structural elements (fig. 1) dominate the geologic structure of south-central Texas: (1) northwest-southeast-trending lineaments that 
extend across Texas (Bolden, 1983); (2) the Ouachita fold belt; and (3) major uplifts and arches, including the Devils River uplift, the Llano uplift (and its subsurface extension, the San Marcos arch), and the Waco uplift (Walper and Miller, 1985).

The system of parallel northwest-southeasttrending lineaments might extend into south-central Texas from west Texas and affect the vertical mobility of the Edwards Plateau and the Gulf Coastal Plain. For example, a block of rocks between two parallel, northwest-southeast lineaments has been uplifted in the Edwards Plateau and subsided in the Gulf Coastal Plain. Adjacent, parallel blocks of rocks similarly have been uplifted. A "hinge line" lies within each block near the inland extent of the Ouachita fold belt and acts as a pivot between the uplifted Edwards Plateau and the subsided Gulf Coastal Plain.

The Ouachita fold belt (not exposed) is in the vicinity of the hinge line between the uplifted craton and the subsiding Gulf Coastal Plain. The Ouachita fold belt contains thrust faults with strikes oriented in a northeasterly direction. The rocks of the Ouachita fold belt include shale, sandstone, slate, phyllite, and schist, most of which have little resistance to horizontal stresses that are oriented parallel to the bedding or cleavage planes. The rocks of the frontal zone of the Ouachita fold belt are slabby sandstone and shale (Flawn and others, 1961). These rocks deeply underlie the Balcones fault zone. Bordering the rocks of the frontal zone on the south are the rocks of the interior zone, which are moderately to strongly metamorphosed. They were rifted during middle Mesozoic time by tectonic forces that opened grabens which generally parallel the Texas coast.

Major uplifts and arches of south-central Texas that are aligned along northwest-trending major lineaments might have resisted northeast-directed, horizontal tectonic stresses during Late Cretaceous time by acting as buttresses to horizontal forces oriented normal to these structures (fig. 1). Horizontal tectonic stress from northern Mexico toward the east caused northwest-trending folds to form in front of the Devils River uplift. Off the southeast side of the Devils River uplift, buttressing structures were not present to resist the northeast-directed force. Late Cretaceous tectonic forces were aligned parallel with the strike of the thrust faults in the Ouachita fold belt and with the trend of grabens resulting from continental rifting during earlier Mesozoic time. Lateral slippage could have occurred along these thrust faults in the rocks of the Ouachita fold belt that underlie the Cretaceous rocks. Consequently, rocks forming the Edwards aquifer were fractured.

\section{Regionai Structurai Geoiogy}

The structural framework of south-central Texas can be subdivided into three areas: the Edwards Plateau, the Balcones fault zone, and the Gulf Coastal Plain.

\section{Structure of the Edwards Plateau}

The Edwards Plateau is an uplifted area of gently dipping strata consisting mostly of carbonates of Early Cretaceous age. It is underlain by a thick crust of metamorphosed igneous and sedimentary rocks of the continental craton. The structure of the Paleozoic sedimentary rocks underlying the Plateau is affected by vertical displacements along the northwest-trending lineaments that traverse the craton.

The surface of the top of the Lower Cretaceous rocks within the Edwards Plateau (north from the Balcones fault zone) is distinctive from that of the Gulf Coastal Plain, which is essentially south of the Balcones fault zone (fig. 3). The change in "structural grain" apparently follows the border between the Ouachita fold belt and the craton, as shown in figure 1. Prior to the Late Cretaceous tectonic activity, the Lower Cretaceous rocks dipped toward the ancestral Gulf of Mexico. This configuration was changed by uplifts of the Edwards Plateau during Late Cretaceous and Cenozoic time. A conspicuous structural feature within the Edwards Plateau is the Medina axis (fig. 3), which is a structural ridge that plunges northeastward from the Devils River uplift. Surficial long fracture zones in the southern Edwards Plateau show northwesterly and northeasterly orientations (fig. 4) as indicated by the studies of Wermund and others (1978).

\section{Structure of the Balcones Fault Zone}

The Balcones fault zone is represented by a series of parallel northeast-trending faults ${ }^{1}$ that commonly are described as normal, high-angle faults with the downthrown side to the southeast. The faults are

\footnotetext{
${ }^{1}$ The configuration of faults shown on selected plates in this report are not always from the same source and thus, are not necessarily identical. Reconciliation of inferred fault locations from previous studies was beyond the scope of this study.
} 


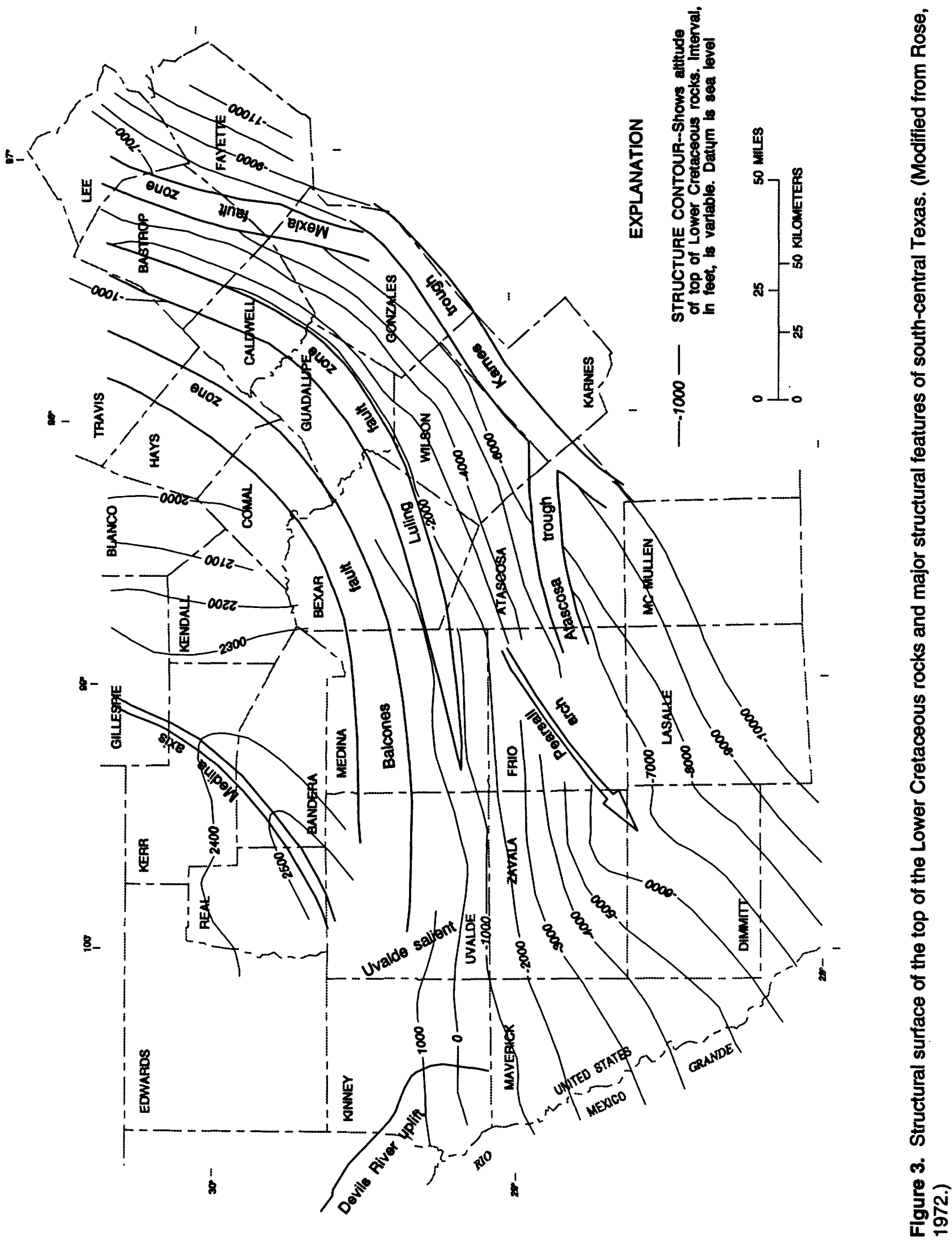




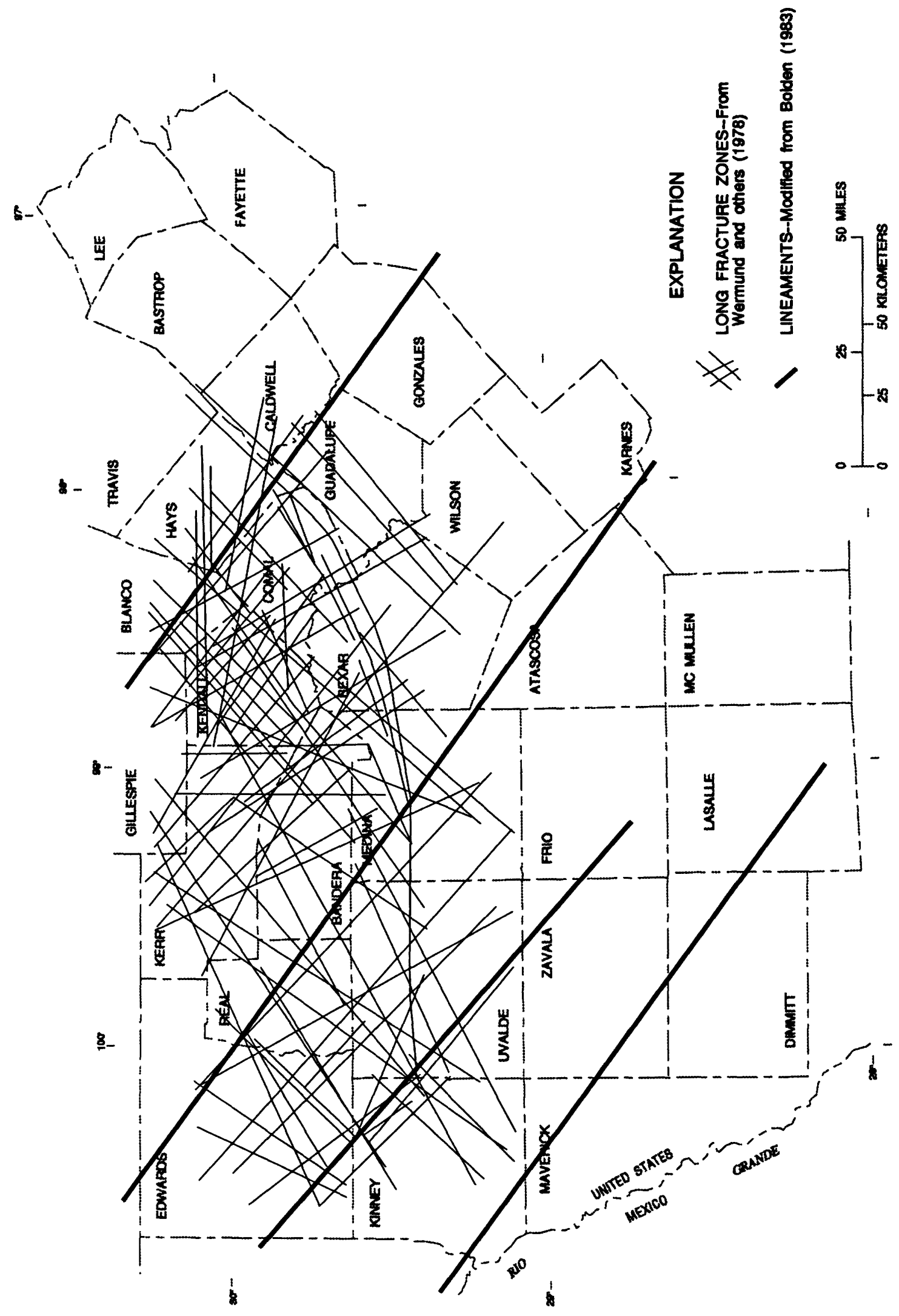

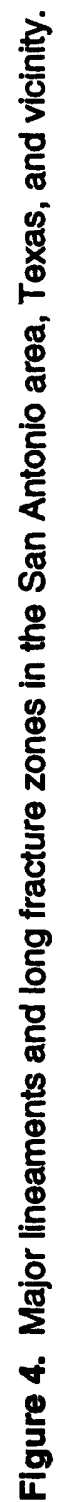


complex in origin, initially being formed in Late Cretaceous time by tectonic forces that laterally displaced the rocks toward the San Marcos arch and caused the fault blocks to rotate with respect to each other in the vicinity of the arch (Rose, 1972). No one individual fault represents the Balcones fault zone. Rather it is a series of en echelon scissor faults; vertical displacements vary along the strike of each individual fault. Abrupt, well defined fault scarps also exist in en echelon patterns along segments of major faults.

The character of vertical displacements (whether the faults are synthetic or antithetic) might be controlled by the Paleozoic and early Mesozoic substrata. The synthetic faults (downfaulted block to the southeast in the direction of the dip of the strata) might be listric faults that follow the thrust planes of the Ouachita fold belt in the frontal zone (fig. 1). With the uplift of the Edwards Plateau, vertical displacements could occur along these pre-existing fault planes. The antithetic faults (upthrown block toward the coast with the dip of the fault plane opposite to the dip of the strata) could be a combination of tensional faults resulting from early Mesozoic rifting and subsequent strike-slippage causing horizontal displacement during Late Cretaceous time. This displacement occurred within the interior zone of the Ouachita fold belt (fig. 1). A large, complex graben lies between the Balcones and Luling fault zones, and smaller horst and graben structures are recognized in the Balcones fault zone.

The Uvalde salient (fig. 3), a complex structural high in Uvalde County, consists of numerous faults of diverse trend around the margins of the feature, where the Edwards Limestone has been raised to the surface. Also in this area are many local volcanic rocks, most of which are plugs of basaltic rocks (igneous intrusive rocks) that are aligned with prominent faults (Rose, 1972). The Uvalde salient is thought to be the result of movement along a major lineament through Uvalde County identified by Bolden (1983) (fig. 4). It probably is associated with a reactivated fault in the Precambrian basement rocks.

The major faults of the Balcones fault zone are shown in plate 4. The block of rocks between Woodard Cave fault and Medina Lake fault occupies much of the Edwards aquifer recharge zone in the area and is less intensively faulted than the rocks southeast of Medina Lake fault. Rocks between Medina Lake fault and Haby Crossing fault and its northeastward extension are in an intensively faulted area traversed by many longitudinal faults that appear to have left-lateral displacement. The rocks between Haby Crossing fault and Pearson fault and its northeastward extension (Comal Springs fault) contain major longitudinal faults of large vertical displacement. These faults essentially overlie the area of the frontal zone (Flawn and others, 1961) of the Ouachita fold belt (fig. 1). The block of rocks southeast of Pearson and Comal Springs faults lies above the interior zone of the Ouachita fold belt and is south of the Edwards aquifer recharge zone. It contains several prominent faults (Luling fault zone) with the upthrown side toward the coast, thus forming a graben. In this graben are complexly rotated scissor faults that extend northeastward from southeastern Medina County across Bexar County to western Guadalupe County.

\section{Structure of the Guif Coastal Plain}

The Gulf Coastal Plain discussed here is roughly that inland part of south-central Texas immediately south of the Edwards Plateau and extending from the Edwards Plateau to about midway to the Gulf of Mexico. It is a subsided area underlain by a continental crust of metamorphosed rocks thinner than the crust of the craton (Sams, 1983). The overlying Paleozoic rocks are deeply buried, but seismic data indicate they are faulted. Cretaceous deposits, consisting mostly of carbonates, accumulated on a back-reef carbonate platform whose deep crustal substrata continued to subside. These rocks were faulted along lines of structural weakness in the underlying substrata. Seismic data and information on structures of oil fields in the area indicate that the coastward dip of the Cretaceous rocks is crossed transversely by high-angle normal faults.

The top of the Lower Cretaceous rocks throughout the inland part of the Gulf Coastal Plain of southcentral Texas dips southeast at about 300 to $400 \mathrm{ft} / \mathrm{mi}$ (fig. 3). This monocline is interrupted in various places by several systems of en echelon normal faults. In addition to the dominant Balcones fault zone at the inner edge of the Gulf Coastal Plain, the Luling fault zone, some $20 \mathrm{mi}$ south of the Balcones fault zone, is of smaller extent and throw. Still farther south are the Karnes trough and the Atascosa trough with its apparent counterpart-the Mexia fault system. The structure and depositional patterns of the Edwards and younger rocks were greatly affected by these troughs, which were subsiding during Early Cretaceous time. 
HYDROGEOLOGIC FRAMEWORK OF THE EDWARDS AQUIFER

\section{Stratigraphic Units and Thickness}

The Edwards aquifer is contained in carbonaterock units of Lower Cretaceous age. Facies within these stratigraphic rock units are determined largely by energy conditions in the Cretaceous depositional provinces of south Texas (Rose, 1972). Depositional environments, matrices, diagenesis, and porosities of typical lithofacies in the Edwards aquifer are summarized in table 2.

Regional stratigraphic studies of the Edwards Limestone or Group ${ }^{2}$ and equivalent rocks in south Texas by Tucker (1962), Winter (1962), Lozo and Smith (1964), Fisher and Rodda (1969), and Rose (1972) have resulted in a better understanding of the regional stratigraphy and have resolved problems of stratigraphic nomenclature and correlation. This report uses the stratigraphic nomenclature proposed by Lozo and Smith (1964) and Rose (1972), which is consistent with the usage in the Geologic Atlas of Texas published by the University of Texas, Bureau of Economic Geology (1974a, b, c, 1977, 1981). Consequently, the nomenclature might not necessarily follow the usage of the USGS.

The Edwards aquifer is represented by three stratigraphic columns across the San Antonio areathe Maverick basin, the Devils River trend, and the San Marcos platform (Rose, 1972). A section showing regional stratigraphic units in the Edwards aquifer from the Maverick basin to the San Marcos platform is shown in figure 5.

In the Maverick basin (fig. 5, table 1), the Edwards aquifer consists of the West Nueces, McKnight, and Salmon Peak Formations (Lozo and Smith, 1964). The West Nueces Formation consists of almost impermeable, nodular mudstone about $70 \mathrm{ft}$ thick in the lower part and miliolid and mollusk-bearing grainstone in the upper $90 \mathrm{ft}$. The upper part contains beds of dolomitized, burrowed wackestone that are leached and form permeable, honeycombed rock in some places. The McKnight Formation consists mostly of lower and upper thin-bedded limestone separated by a black, fissile, limey mudstone about $20 \mathrm{ft}$ thick. The lower limestone unit, about $60 \mathrm{ft}$ thick, consists of

\footnotetext{
2 The Edwards Limestone was raised to a stratigraphic group by Rose (1972).
}

slightly permeable fecal-pellet limey mudstone overlain by shell-fragment grainstone containing zones of interbedded collapse breccia. The upper limestone, which is about $45 \mathrm{ft}$ thick, consists mostly of thinbedded shaley limestone including collapse breccia, and associated evaporite. The Salmon Peak Formation consists of about $300 \mathrm{ft}$ of dense, massive, lime mudstone containing chert in the lower part and about $80 \mathrm{ft}$ of crossbedded, rounded shell-fragment, permeable, reef-talus grainstone and caprinid boundstone in the upper part.

In the Devils River trend, the Edwards aquifer consists of the Devils River Limestone and typically is about $550 \mathrm{ft}$ thick. The range in thickness is about 400 to $800 \mathrm{ft}$. It consists of marine to supratidal deposits in the lower part and complex reefal and inter-reefal deposits in the upper part. Rocks grade upward from about $90 \mathrm{ft}$ of poorly permeable, nodular, dense, shaley limestone above the contact with the Glen Rose Limestone, to about $220 \mathrm{ft}$ of tidal and marine wackestone and mudstone containing burrowed or honeycombed beds, some of which are highly permeable. Above these rocks is about $60 \mathrm{ft}$ of mudstone and permeable collapse breccia. The upper $180 \mathrm{ft}$ represent shallow marine deposits consisting of biohermal rudist mounds, talus grainstone, and inter-reefal wackestone.

The basal stratigraphic unit of the Edwards Group on the San Marcos platform is the Kainer Formation, which typically is about $300 \mathrm{ft}$ thick. It ranges in thickness from 250 to $400 \mathrm{ft}$. The formation consists of three members. The basal nodular member (infor$\mathrm{mal}$ ) is a marine deposit consisting of dense, nodular, stylolitic wackestone. The dolomitic member (informal) consists mostly of tidal, burrowed, and dolomitized wackestone with large permeability. The upper part of the dolomitic member contains leached evaporitic deposits of the Kirschberg evaporite. The uppermost member of the Kainer Formation is the grainstone member (informal), which consists of well cemented, miliolid grainstone with lesser beds of mudstone and wackestone. At many locations, the allochems of the grainstone have been partially dissolved, resulting in a slightly to moderately permeable rock.

The upper stratigraphic unit of the Edwards Group on the San Marcos platform is the Person Formation (Rose, 1972), which typically is about $200 \mathrm{ft}$ thick. It ranges in thickness from about 180 to $250 \mathrm{ft}$. Rose (1972) identified five informal members of the Person Formation in the deep subsurface of south Texas north of the Stuart City reef. The basal member 

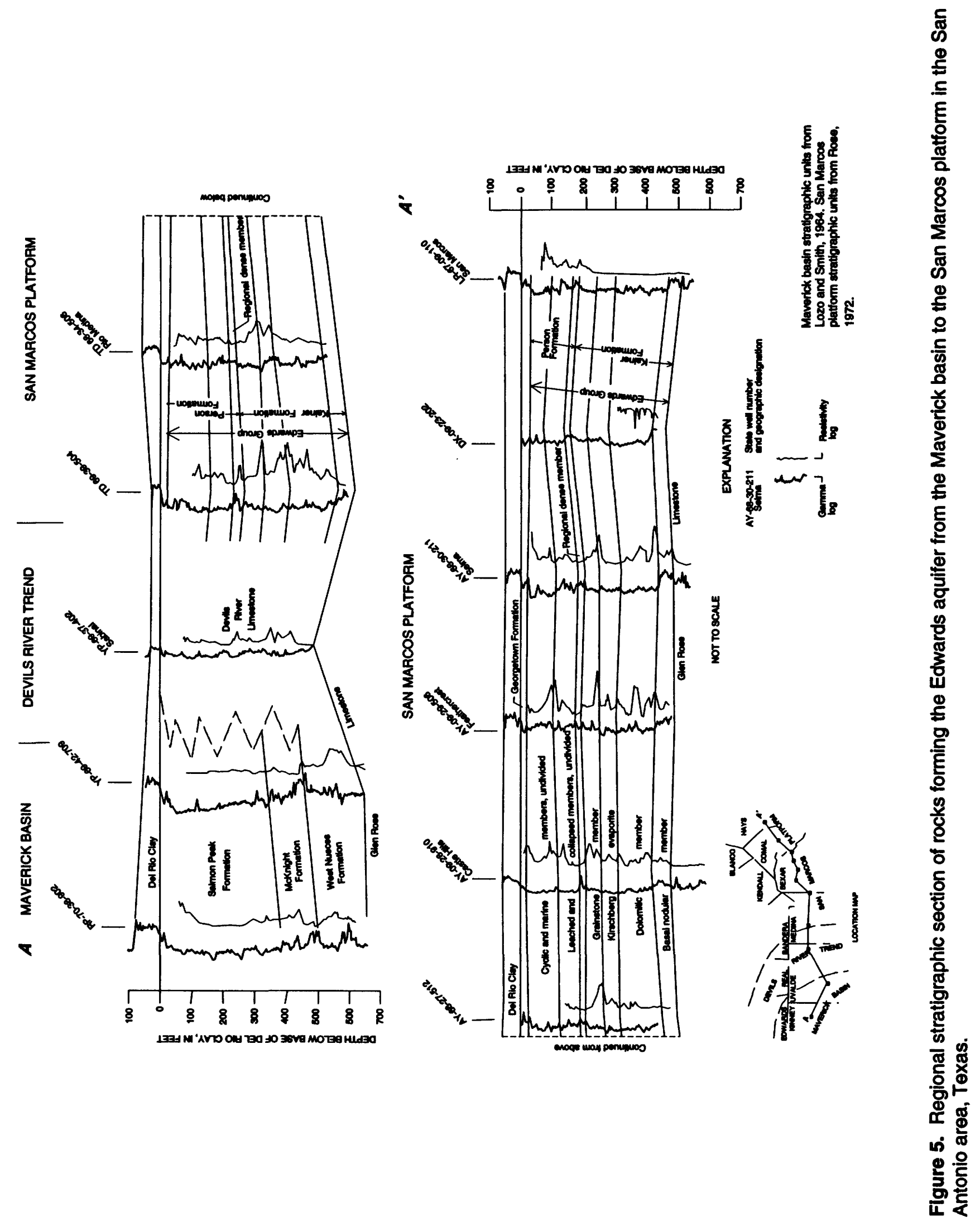
Tabie 2. Depositional environments, matrices, diagenesis, and porosities of typical lithofacies in the Edwards aquifer in the San Antonio area, Texas ${ }^{1}$

$[--$, unknown]

\begin{tabular}{|c|c|c|c|c|c|}
\hline Uthofacles & $\begin{array}{l}\text { Sedimentery } \\
\text { structures and } \\
\text { depoeltionel } \\
\text { environment }\end{array}$ & Matrix & Allocheme or cryetale & Dlegencels & Porodity \\
\hline \multicolumn{6}{|l|}{ Mudstone } \\
\hline $\begin{array}{l}\text { Dense, non- } \\
\text { fossiliferous }\end{array}$ & $\begin{array}{l}\text { Mudcracks, irregular } \\
\text { lamination, stroma- } \\
\text { tolitic, brecciated; } \\
\text { supratidal. }\end{array}$ & $\begin{array}{l}\text { Carbonate mud is } \\
\text { greater than } 90 \text { per- } \\
\text { cent of the rock. }\end{array}$ & $\begin{array}{l}\text { Lithoclasts and algal frag- } \\
\text { ments. Grains are iso- } \\
\text { lated in mud matrix. }\end{array}$ & $\begin{array}{l}\text { Commonly is } \\
\text { partly to com- } \\
\text { pletely dolo- } \\
\text { mitized. }\end{array}$ & $\begin{array}{l}\text { Little effective interconnected porosity except for } \\
\text { some zones of leached collapse breccia. Porosity } \\
\text { consists almost entirely of micropores that are } \\
\text { poorly interconnected. }\end{array}$ \\
\hline $\begin{array}{l}\text { Pelletoidal, } \\
\text { whole fossil, } \\
\text { and shaley }\end{array}$ & $\begin{array}{l}\text { Laminated, burrowed, } \\
\text { churned, nodular, and } \\
\text { dolomitized; tidal flat to } \\
\text { lagoonal. }\end{array}$ & $\begin{array}{l}\text { Carbonate mud, might } \\
\text { be pelleted. }\end{array}$ & $\begin{array}{l}\text { Whole fossil and fossil } \\
\text { fragments. Grains are } \\
\text { isolated in mud matrix. }\end{array}$ & $\begin{array}{l}\text { Commonly is } \\
\text { partly dolo- } \\
\text { mitized. } \\
\text { Might be } \\
\text { chalky. }\end{array}$ & $\begin{array}{l}\text { Effective porosity is dependent on leaching. } \\
\text { Honeycombed rock is developed in some leached. } \\
\text { mottled, and burrowed zones. Nodular and pel- } \\
\text { leted zones generally are dense and nonporous. } \\
\text { Large voids commonly are molds after megafos- } \\
\text { sils. Porosity in chalk is due to micropores. }\end{array}$ \\
\hline
\end{tabular}

Wackestone

Fossil frag-

ment, ndis-

tid, and

whole fossil

\section{Packstone}

Fossil and fossil fragment, intraclastic
Burrowed and churned; lagoonal.
Carbonate mudmight be pelleted, might be converted to microspar. Comprises more than onehalf of the rock constituents.
Whole mollusk, miliolid, intraclasts. Algal grains are isolated in mud matrix.
Commonly is partly dolomitized. Might be chalky.
Effective porosity is dependent on the leaching of the mudstone to large, euhodral dolomite thombs. Pore types include molds, intererystalline voids, and pinpoint vugs. grains and the conversion of a substantial part of

\section{Grainstone}

Miliolid and

fossil frag-

ment

Boundstone

Algal and ree-

fal

Sedimentary structure
indicates growth posi-
tion of organisms; patch reefs to algal flats.

Dolomite

Crossbedded; shallow marine.
Moderately disturbed: lagoonal to open marine.

Spar.

Carbonate mud, generally comprises less than one-half of the rock constituents. Larger grains are touching.

Commonly is dolomitized and leached.

Miliolids and fossil talus. Commonly is Grains are touching.

tightly cemented.
Effective porosity is substantial where dolomitization and leaching have occurred. Pore types are vugs, interparticle, and moldic.
Effective porosity is variable. Very porous where well leached. Some grainstone leached to chalk, a very porous rock that drains slowly.

Whole mollusk fossils, commonly large nudists, algal mats.

Dolomite rhombs, ranging from very finegrained subhedral to coarsely crystalline euhodral.
Algal zones commonly are dolomitized.
Variable effective porosity. Leached rudistid beds have little to moderate porosity.
Some dolomite is extensively leached.
Generally, the coarsely sucrosic dolomite has the greatest effective porosity. Porosity is increased by vugs. The fine-grained dolomite has little effective porosity.
No trace of original texture where dolomitization is complete.
Recrystallized

limestone

No trace of original tex- Spar. ture in matrix.
Matrix has no effective porosity, but secondary vugs might be large and well connected. Boxwork porosity is developed in some evaporitic zones.

${ }^{1}$ Modified from Maclay and Small, 1984. 
is a laterally extensive marine deposit consisting of poorly permeable, dense, carbonate mudstone known as the regional dense member (informal) (fig. 5). It is easily recognized in test-hole cores by its lithology and on geophysical logs by distinct shifts in the log traces. The overlying members, the leached and collapsed members, undivided (informal), basically consist of limestone and dolomite. These members contain highly permeable units that are formed by collapse breccia and by dolomitized and burrowed wackestone (biomicrites). The uppermost member that can be identified in the test-hole cores is the marine member (informal), which consists basically of limestone and dolomite, and more specifically of rudist-bearing wackestone and packstone and shell-fragment grainstone. The cyclic member (informal), which could not be identified in the test-hole cores, might be wholly or partly eroded in the area.

The uppermost stratigraphic unit of the Edwards aquifer in the San Marcos platform is the Georgetown Formation. This formation consists of dense, argillaceous limestone that ranges in thickness from 20 to $60 \mathrm{ft}$.

Overall, the approximate thickness of the freshwater zone in the Edwards aquifer ranges from 400 to $800 \mathrm{ft}$ and averages about $550 \mathrm{ft}$. The thickness increases toward the west and south.

The confining units of the Edwards aquifer in the San Antonio area consist of the underlying Glen Rose Limestone and the overlying Del Rio Clay. Both units have, for the most part, relatively small permeability (table 1). In many places these confining units are cut by faults that extend upward from subjacent geologic units; however, because of the plasticity of the rocks of the confining units, fractures tend to be closed and have mostly limited permeability.

\section{Structural Framework}

The top of the Edwards aquifer was selected for subsurface mapping because the contact between the aquifer and the overlying Del Rio Clay can be identified easily on geophysical logs and drillers' reports. The structure of the top of the Edwards aquifer determined from these logs and reports is shown in plate 5. Structural mapping in the outcrop area to the north was not done; however, the structural complexity shown in the map extends into the outcrop area.

Plate 5 shows that the generally south-tosoutheast slope of the top of the aquifer is interrupted by numerous faults and other structural features. The trace of the zero contour line forms a stair-stepped pattern rising toward the Comal-Hays County line where the San Marcos arch plunges to the southeast. This pattern reflects the en echelon pattern of the left-lateral horizontal displacement of the northeast-trending faults.

The configurations of the top of the Edwards aquifer and the base of the aquifer (top of Glen Rose Limestone) are locally complex because of faulting. Along segments of some major faults, the entire aquifer is displaced vertically so that lateral continuity is completely removed in the direction perpendicular to the fault plane (Maclay and Small, 1984). At such places, this disruption has resulted in the aquifer being greatly compartmentalized. Discussion of the role of faults as barriers to ground-water flow is given in the section "Geologic Controls on Local Ground-Water Flow."

The vertical displacements of faults in the Edwards aquifer are documented on 27 hydrogeologic sections by Small (1986). The sections show structural relations along lines oriented approximately south-southeast, generally parallel to the regional dip. This orientation is perpendicular to the major faults of the Balcones fault zone. Inspection of the hydrogeologic sections shows that, locally, the vertical displacements along the faults exceed the thickness of the Edwards aquifer, and that the downthrown block is most commonly to the southeast.

Four hydrogeologic sections were selected as representative sections showing fault displacements and fault structures (pl. 6). Section $\boldsymbol{A}-\boldsymbol{A}^{\prime}$ crosses Comal County and ends near New Braunfels. The section (fig. 6 ) indicates the aquifer is completely offset by faults near $A^{\prime}$. Section $B-B^{\prime}$ (fig. 7) crosses eastern Bexar County and shows a horst near well AY-68-29-811. Section $C-C^{\prime}$ (fig. 8) crosses eastern Medina County and illustrates the structural compartmentalization of the Edwards aquifer; along the section, the aquifer is entirely offset vertically at three locations. Section $D$ $D^{\prime}$ (fig. 9) crosses eastern Uvalde County, and indicates no distinct compartmentalization of the aquifer along this hydrogeologic section.

\section{Deveiopment and Distribution of Porosity and Permeabliity}

The Edwards aquifer is the product of geologic processes that operated during the past, when regional 


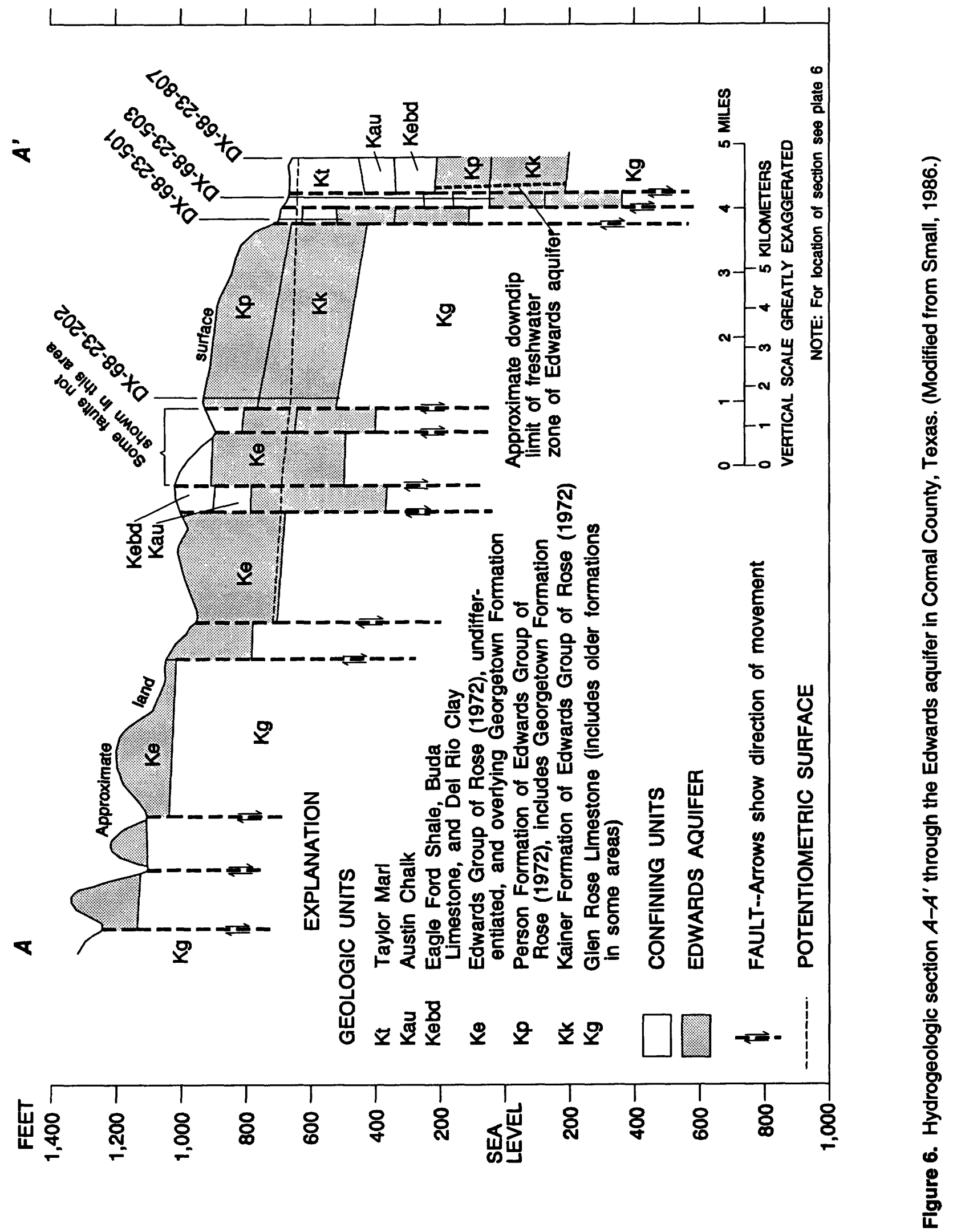


in

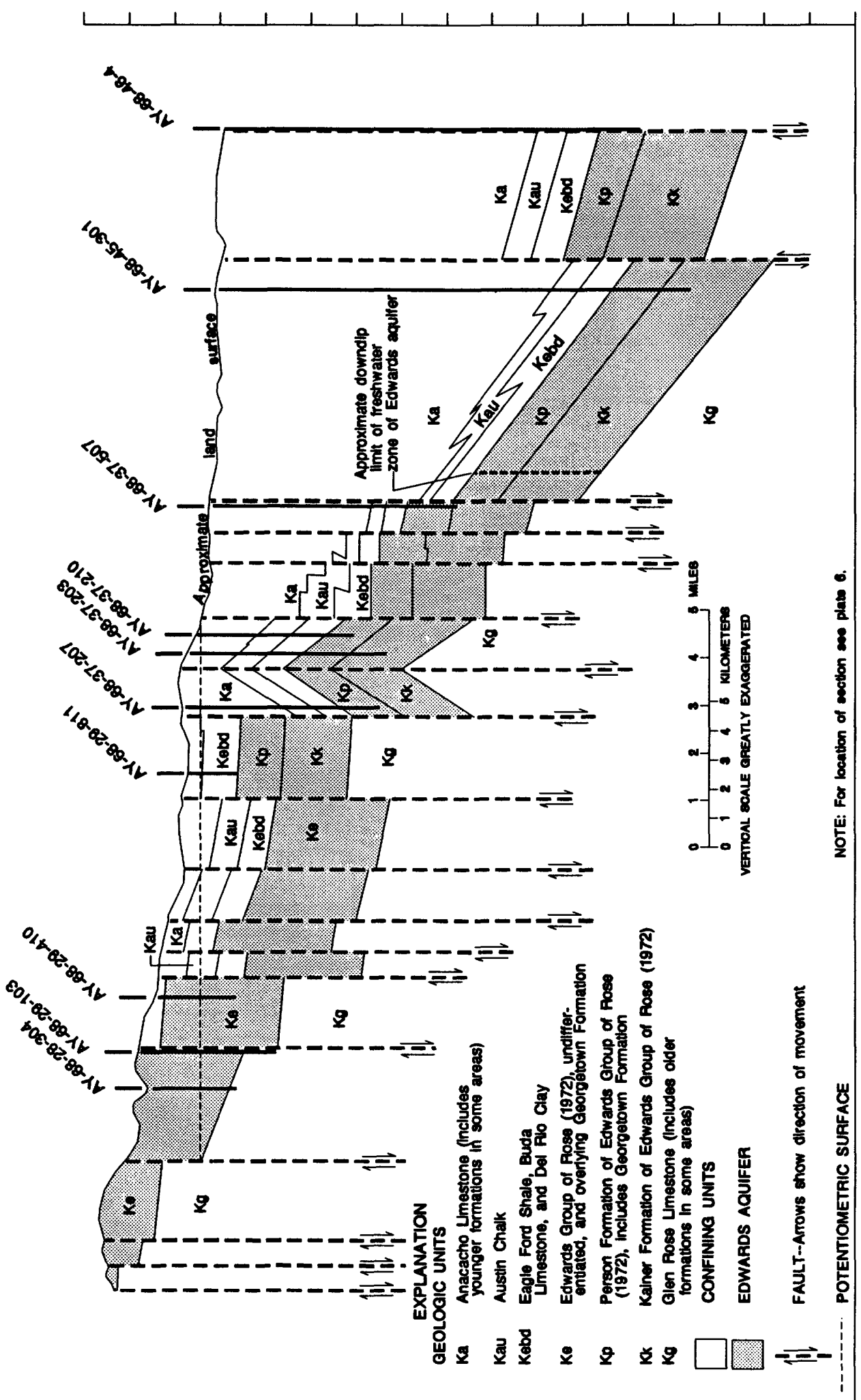

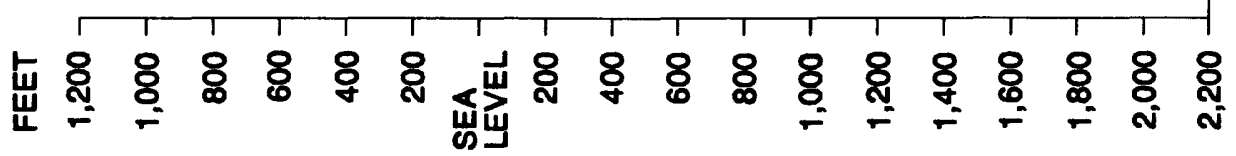

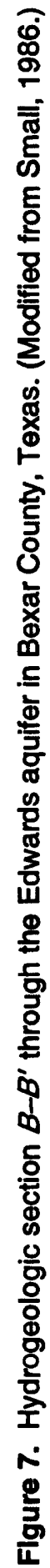




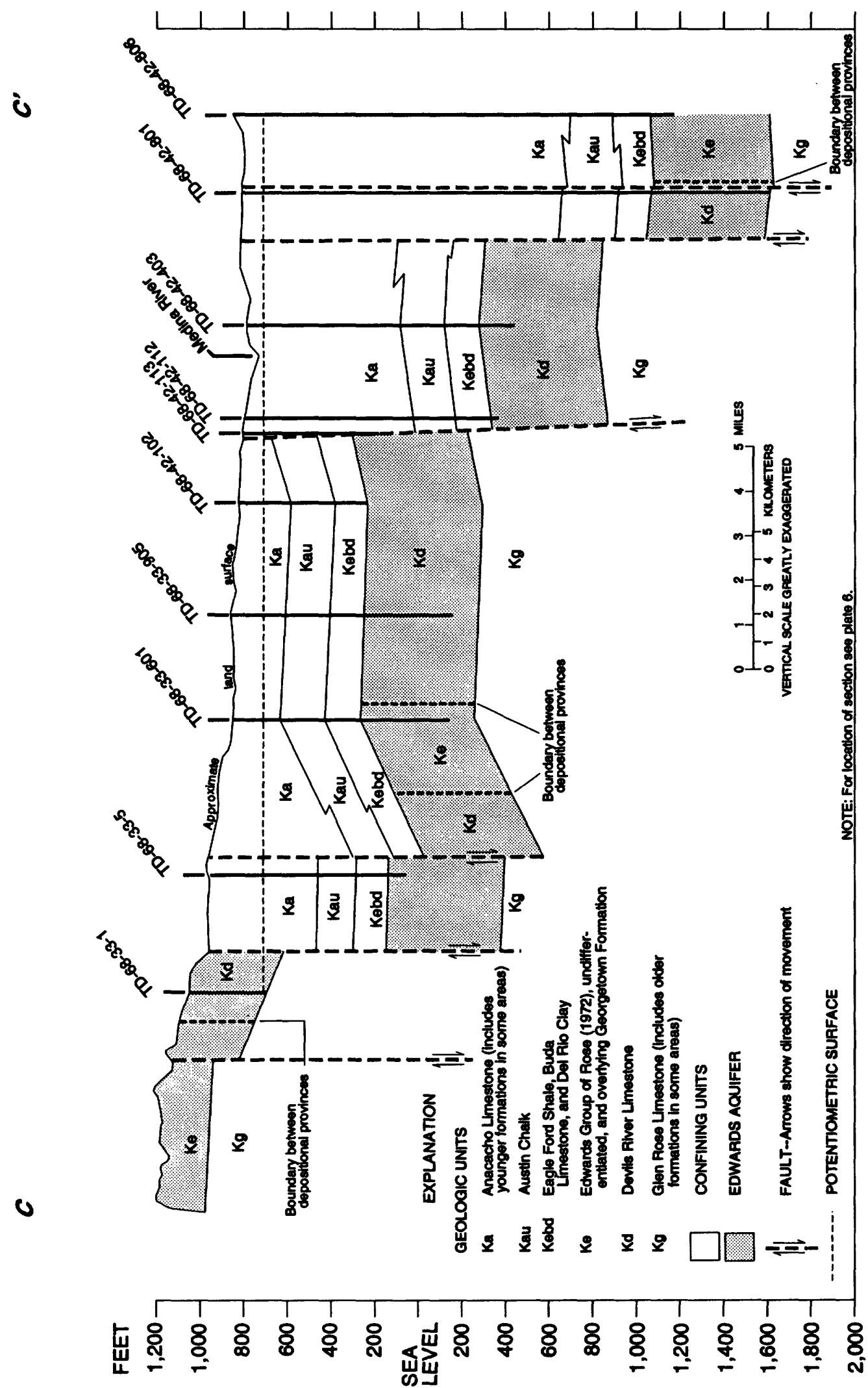

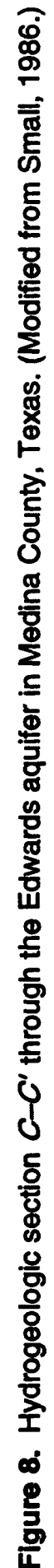




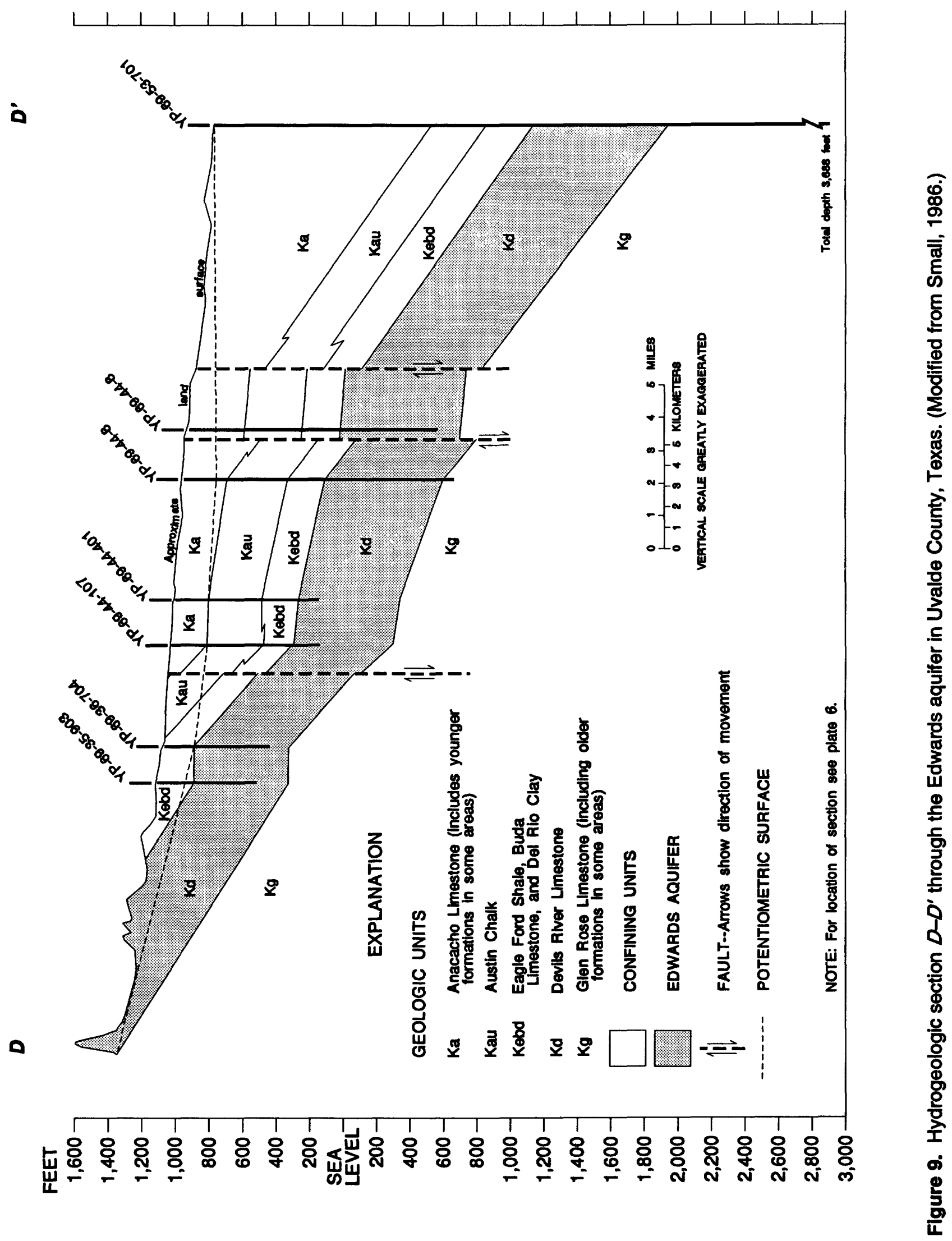


uplift and subsequent erosional degradation of the Edwards Plateau removed the Upper Cretaceous deposits from central Texas and exposed the rocks of the Edwards Group. An aquifer containing circulating freshwater resulted first from chemical dissolution by meteoric water after the rocks of the Edwards were exposed. With continued erosion resulting from episodic uplifts, the rocks of the Edwards also were removed from vast areas of north-central Texas by streams draining to the northwest.

The development and distribution of porosity and permeability in the Edwards aquifer are complex. The original texture of the rocks, the diagenetic processes that have occurred since deposition, and the locations of the confined and unconfined parts of the modern ground-water-flow system are major factors that have had an influence on porosity and permeability.

Caves and solution channels, elevated substantially above the altitude of the present-day drainages, exist within the Edwards Plateau. These caves and channels represent the effects of extinct groundwater-flow systems. As differential uplift toward the southwest continued and erosion followed, the rocks of the Edwards Group were progressively uplifted and gradually exposed from the northeast toward the southwest along the trend of the buried Ouachita fold belt and the overlying Balcones fault zone. Within this trend, the older flow systems lie to the northeast, and progressively younger flow systems were developing to the southwest. The current stage of aquifer evolution within the Balcones fault zone is represented by the Edwards aquifer in the San Antonio area.

The stages of evolution of the Edwards aquifer from a deeply buried, moderately cemented, dolomitized carbonate rock of small permeability, are marked by changes in geologic conditions which control porosity- and permeability-forming processes. The geologic factors affecting the Edwards aquifer since Early Cretaceous time and the changes in porosity and permeability resulting from the geologic processes are summarized in table 3.

The diagenetic processes affecting porosity and permeability in the present-day Edwards aquifer include dissolution, recrystallization, and dedolomitization (fig. 10). Dissolution that has occurred along bedding planes can be observed in the outcrop (Small and Maclay, 1982). Some bedding planes and fractures are iron stained and show other evidence of groundwater circulation. The large porosity and permeability of the unconfined Edwards aquifer are attributable to this dissolution of limestone by circulating ground water and subsequent development of a cavernous network along fractures. Dissolution related to erosional surfaces is difficult to document; however, travertine and "cave popcorn," which are evidence of a previous unsaturated zone, have been observed in cores obtained from the confined parts of the aquifer in the eastern part of the San Antonio area. These deposits probably were formed under unsaturated conditions that existed in Early Cretaceous time before the rocks forming the Edwards aquifer were deeply buried by Upper Cretaceous deposits.

Recrystallization (neomorphism) of calcitic mudstone and wackestone and dedolomitization of dolomite are prevalent in the freshwater part of the confined Edwards aquifer. These diagenetic processes resulted in a major change in the character of porosity in the aquifer and have substantially increased pore sizes and their interconnections, particularly in dolomitic lithofacies (Maclay and Small, 1984; Ellis, 1985). Dedolomitization (calcification) has been the dominant chemical process that has produced large effective porosity and permeability in the freshwater part of the confined aquifer.

The mineralogy and texture of the rocks containing saline water in the Edwards aquifer have not changed substantially by diagenetic processes involving freshwater during Cenozoic time. These rocks are mostly dolomitic and could contain unoxidized organic material, petroleum, and minerals such as pyrite, gypsum, and celestite. The rocks containing saline water are more porous than the stratigraphically equivalent rocks updip that contain freshwater. However, the voids are predominantly small interparticle, intraparticle, and intercrystalline pores. The permeability of the rocks is small because of limited interconnection between the pores and lack of substantial dissolution along fractures. In general, pore types in the rocks containing saline water are associated predominantly with rock fabric rather than with fractures and secondary sedimentary structures.

Dolomite crystals have various morphologies in the rocks containing saline water. Most dolomite in the Edwards aquifer was formed by replacement or recrystallization of micrites. Crystals up to several hundred microns in diameter with nearly perfect development of crystal faces (clear euhedral) are evident in some massive dolomite beds near the transition zone from fresh to saline water in the Edwards aquifer. Other 


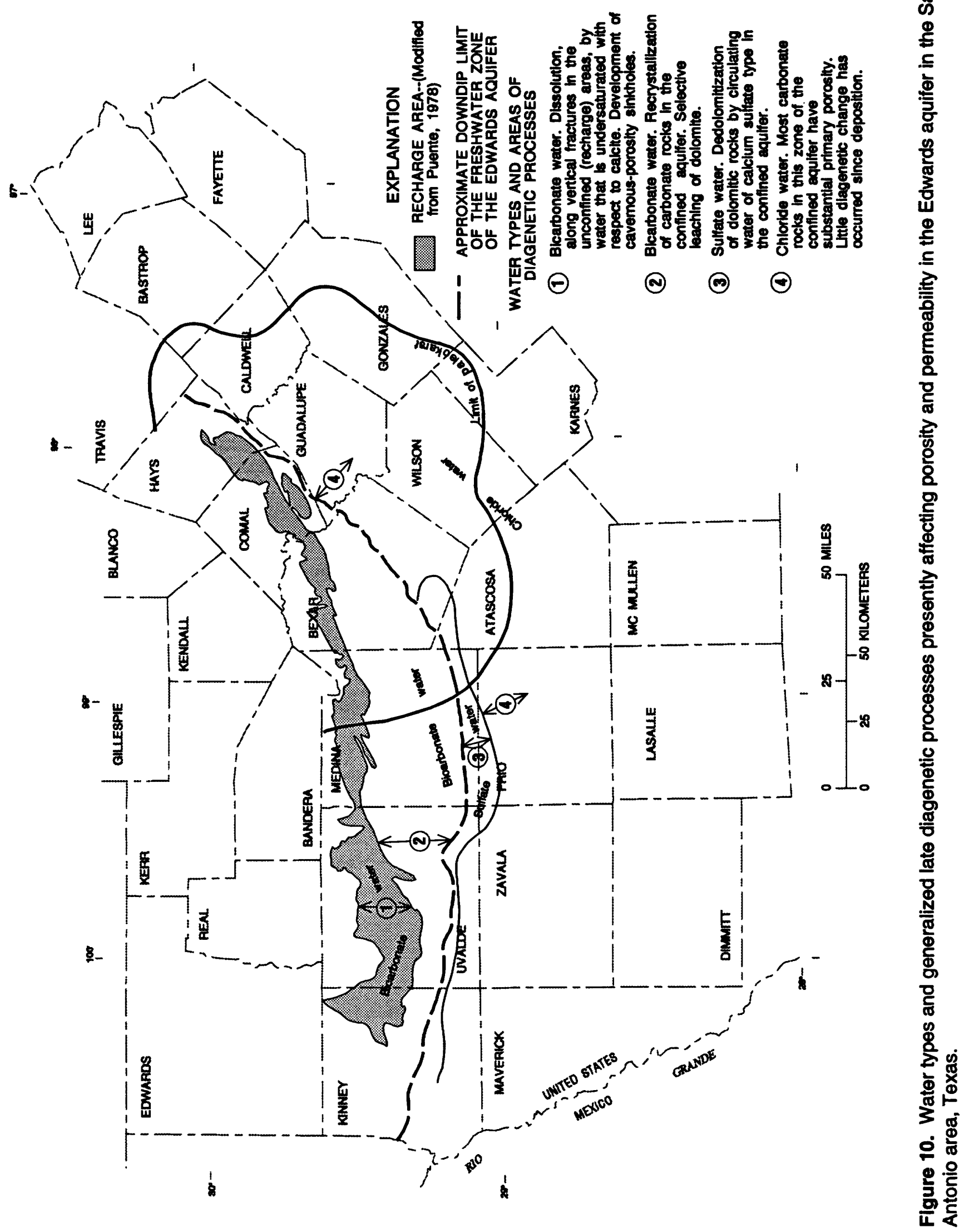


Table 3. Geologic factors affecting the development of porosity and permeability in the Edwards aquifer in the San Antonio area, Texas

\begin{tabular}{|c|c|c|c|c|c|}
\hline Time & $\begin{array}{c}\text { Diegenotic and goologle } \\
\text { environments }\end{array}$ & Tectonic ectivity & Ceologle proceseses & Lthology & Poroelty and permeablitity \\
\hline $\begin{array}{l}\text { Early } \\
\text { Cretaceous }\end{array}$ & $\begin{array}{l}\text { Deposition and shallow burial. } \\
\text { Involves barrier reefs, exten- } \\
\text { sive beck-roef lagoons, patch } \\
\text { reefs, and tidal flats or sablhas. } \\
\text { Deep-water deposition in } \\
\text { Maverick basin. }\end{array}$ & $\begin{array}{l}\text { Slowly subsiding carbon- } \\
\text { ate platform. Slower } \\
\text { subsidence on San } \\
\text { Marcos arch. More } \\
\text { rapid subsidence in } \\
\text { Maverick basin. }\end{array}$ & $\begin{array}{l}\text { Shallow seas cyclically advance } \\
\text { and retreat onto the continental } \\
\text { platform of low relief. Dolo- } \\
\text { mitization of tidal sediments. } \\
\text { Some cementation by micritiza- } \\
\text { tion of many carbonate frag- } \\
\text { ments. }\end{array}$ & $\begin{array}{l}\text { Cyclically stratified lime- } \\
\text { stone, dolomite, and } \\
\text { evaporite. Rock types } \\
\text { on San Marcos arch are } \\
\text { mostly wackestone, } \\
\text { packstone, and grain- } \\
\text { stone. Collapse breccia } \\
\text { common in evaporites. } \\
\text { Rock type is mostly lime } \\
\text { mudstone. }\end{array}$ & $\begin{array}{l}\text { High porosity but low per- } \\
\text { meability. Porosity } \\
\text { related to sedimentation } \\
\text { fabric. Early cementa- } \\
\text { tion partially filled } \\
\text { pores. Dolomitization } \\
\text { of tidal-flat deposits, } \\
\text { particularly burnowed } \\
\text { wackestone. }\end{array}$ \\
\hline $\begin{array}{l}\text { Early } \\
\text { Middle } \\
\text { Cretaceous }\end{array}$ & $\begin{array}{l}\text { Subaerial exposure. Phreatic } \\
\text { environment on San Marcos } \\
\text { arch causes solutioning of car- } \\
\text { bonate rocks and produces cav- } \\
\text { emous porosity in the upper part } \\
\text { of the Edwards. }\end{array}$ & $\begin{array}{l}\text { Uplift within the San } \\
\text { Marcos arch. Decreased } \\
\text { rate of subsidence in } \\
\text { Maverick basin. }\end{array}$ & $\begin{array}{l}\text { Erosion and karstification on San } \\
\text { Marcos arch. Cementation and } \\
\text { solutioning within a zone of cir- } \\
\text { culating meteoric water. Gen- } \\
\text { eral unconformity produced. } \\
\text { Rock alteration near unconfor- } \\
\text { mity. }\end{array}$ & $\begin{array}{l}\text { Fine-grained carbonate } \\
\text { predominates in } \\
\text { Maverick basin. }\end{array}$ & $\begin{array}{l}\text { Total permeability and } \\
\text { porosity of rocks } \\
\text { enhanced due to develop- } \\
\text { ment of rock alteration } \\
\text { associated with the } \\
\text { unconformity. }\end{array}$ \\
\hline $\begin{array}{l}\text { Middle } \\
\text { Cretaceous } \\
\text { to present }\end{array}$ & $\begin{array}{l}\text { Deep burial of Edwards Lime- } \\
\text { stone in the subsiding Texas } \\
\text { Gulf Coastal Plain near Stuart } \\
\text { City reef. Brine saturates the } \\
\text { deeply buried sediments. } \\
\text { Edwards aquifer possibly } \\
\text { affected by geopressure because } \\
\text { of invading fluids from com- } \\
\text { pacting sediment and from } \\
\text { hydration of clay minerals. }\end{array}$ & $\begin{array}{l}\text { Deposition and subsid- } \\
\text { ence in association with } \\
\text { development of the Gulf } \\
\text { of Mexico. Faulting and } \\
\text { fracturing during period } \\
\text { of Laramidian orogeny. } \\
\text { Wrench faulting during } \\
\text { periods of great horizon- } \\
\text { tal stresses. Normal } \\
\text { faulting during late Ter- } \\
\text { tiary and Quaternary. }\end{array}$ & $\begin{array}{l}\text { Compaction of sediments, } \\
\text { stylolitization. Hydrofractur- } \\
\text { ing, wrench faulting, normal } \\
\text { faulting, very slow updip circu- } \\
\text { lation of water from compacting } \\
\text { sediments. Water moves along } \\
\text { paths controlled by rock texture } \\
\text { within the Edwards and along } \\
\text { faults cutting the Edwards and } \\
\text { overlying sediments. }\end{array}$ & $\begin{array}{l}\text { Compacted carbonate } \\
\text { sediments having well } \\
\text { preserved textural fea- } \\
\text { tures. Fossil fragments } \\
\text { are identifiable. Oil } \\
\text { stains are common. } \\
\text { Stylolites are well devel- } \\
\text { oped in mudstone and } \\
\text { wackestone. }\end{array}$ & $\begin{array}{l}\text { Moderate porosity and per- } \\
\text { meability related to tex- } \\
\text { mre. Some dolomite has } \\
\text { well developed intercrys- } \\
\text { talline porosity. Some } \\
\text { miliolid grainstone is } \\
\text { poorly cemented and } \\
\text { moderately permeable. } \\
\text { Permeability at great } \\
\text { depth is more related to } \\
\text { rock texture than frac- } \\
\text { tures. High confining } \\
\text { pressure decreases the } \\
\text { width of open fractures } \\
\text { and thereby contributes } \\
\text { to a permeability reduc- } \\
\text { tion relative to shallow } \\
\text { deposits. }\end{array}$ \\
\hline $\begin{array}{l}\text { Middle } \\
\text { Tertiary to } \\
\text { present }\end{array}$ & $\begin{array}{l}\text { Moderate depth of burial immedi- } \\
\text { ately downdip from the Bal- } \\
\text { cones fault zone. Water of } \\
\text { meteoric origin predominates. } \\
\text { Varying freshwater heads con- } \\
\text { trol the circulation of fresh and } \\
\text { saline ground water. (These } \\
\text { heads change with the eleva- } \\
\text { tions of the land surface.) In } \\
\text { general, rocks of this diagenetic } \\
\text { stage have little capacity to } \\
\text { transmit large rates of water } \\
\text { except, perhaps, the karstified } \\
\text { rocks associated with the } \\
\text { unconformity produced in Cre- } \\
\text { taceous time. These rocks have } \\
\text { yielded large volumes of water } \\
\text { at a substantial pumping rate. } \\
\text { Much of the saline-water pump- } \\
\text { age has occurred at the shallow } \\
\text { Edwards oil fields in Guadalupe } \\
\text { and Caldwell Counties. }\end{array}$ & $\begin{array}{l}\text { Uplift of the Edwards Pla- } \\
\text { teau resulting from isos- } \\
\text { tatic adjustments in } \\
\text { response to the rapid } \\
\text { deep subsidence of the } \\
\text { Gulf of Mexico. Move- } \\
\text { ments are controlled by } \\
\text { major lineaments that } \\
\text { extend from the Edwards } \\
\text { Plateau to the subsur- } \\
\text { face of the Gulf Coastal } \\
\text { Plain. The Edwards } \\
\text { Limestone progressively } \\
\text { uplifted toward the } \\
\text { Edwards Plateau. In } \\
\text { more recent time, the } \\
\text { western part of the } \\
\text { Edwards Plateau rising } \\
\text { faster than the eastern } \\
\text { part. }\end{array}$ & $\begin{array}{l}\text { Meteoric water from the fresh- } \\
\text { water Edwands aquifer mixes } \\
\text { with nonmeteoric water from } \\
\text { downdip source. (The connate } \\
\text { water downdip is from compac- } \\
\text { tion of deeply buried sediment } \\
\text { and from clay minerals that } \\
\text { have changed their hydration } \\
\text { state.) Greater uplift in the west } \\
\text { forces a greater flux through the } \\
\text { westem zone of mixed water. } \\
\text { Some saturation of pores by } \\
\text { petroleum. Decreased or stabi- } \\
\text { lized compaction and styloliti- } \\
\text { zation. Increased fracturing due } \\
\text { to tensional stresses in Balcones } \\
\text { fault zone. Slow circulation of } \\
\text { ground water of mixed origin } \\
\text { occurs along the buried uncon- } \\
\text { formity and associated zone of } \\
\text { karstification. Slow circulation } \\
\text { of water flushes oil toward } \\
\text { closures. }\end{array}$ & $\begin{array}{l}\text { Well preserved textured } \\
\text { fabric. No substantial } \\
\text { increase in cementation } \\
\text { from Cretaceous time. }\end{array}$ & $\begin{array}{l}\text { Porosity and permeability } \\
\text { are related to texture and } \\
\text { fracture openings. } \\
\text { Widths of fracture open- } \\
\text { ings are controlled by } \\
\text { pressure exerted by the } \\
\text { rocks overlying the } \\
\text { Edwards. As unloading } \\
\text { by erosion progresses, } \\
\text { the widths of fracture } \\
\text { openings increase; the } \\
\text { permeability related to } \\
\text { fracture width increases } \\
\text { exponentially. }\end{array}$ \\
\hline
\end{tabular}


Table 3. Geologic factors affecting the development of porosity and permeability in the Edwards aquifer in the San Antonio area, Texas-Continued

\begin{tabular}{|c|c|c|c|c|c|}
\hline TIme & $\begin{array}{c}\text { Diagenetic and geologic } \\
\text { environments }\end{array}$ & Tectonic setivity & Geologle procesenes & Lthology & Porosity and permeability \\
\hline $\begin{array}{l}\text { Late Tertiary } \\
\text { to } \\
\text { Quaternary }\end{array}$ & $\begin{array}{l}\text { Shallow burial. Last stage of } \\
\text { burial before exposure of } \\
\text { Edwards Limestone within the } \\
\text { Balcones fault zone. }\end{array}$ & $\begin{array}{l}\text { Continued uplift of the } \\
\text { Edwards Plateau. Nor- } \\
\text { mal faulting within the } \\
\text { Balcones fault zone dis- } \\
\text { rupts aquifer's geome- } \\
\text { try. Movement along } \\
\text { reactivated faults is con- } \\
\text { centrated along a "hinge } \\
\text { line" which follows the } \\
\text { Balcones fault zone. }\end{array}$ & $\begin{array}{l}\text { Active dissolution near the inter- } \\
\text { face between freshwater and } \\
\text { saline water. Water becomes } \\
\text { unsaturated with respect to } \\
\text { dolomite and saturated with } \\
\text { respect to calcite. Much recrys- } \\
\text { tallization and increased cemen- } \\
\text { tation by calcite. Much of the } \\
\text { original textural components of } \\
\text { the rocks is destroyed. Dedolo- } \\
\text { mitization. Selective leaching of } \\
\text { dolomite and evaporites. } \\
\text { Decreasing rock pressure on } \\
\text { Edwards Limestone and widen- } \\
\text { ing of fracture openings. Mod- } \\
\text { erate rate of ground-water } \\
\text { circulation. }\end{array}$ & $\begin{array}{l}\text { Strongly altered rocks. } \\
\text { Much calcite cementa- } \\
\text { tion. }\end{array}$ & $\begin{array}{l}\text { Cementation of grainstone } \\
\text { and dedolomitization of } \\
\text { dolomite produces a net } \\
\text { loss in total porosity. } \\
\text { Secondary porosity is } \\
\text { developed in burrowed } \\
\text { tidal-flat deposits, } \\
\text { evaporites, and reef } \\
\text { rocks. Permeability is } \\
\text { strongly controlled by } \\
\text { secondary porosity } \\
\text { developed in particular } \\
\text { stratigraphic units. }\end{array}$ \\
\hline $\begin{array}{l}\text { Late Tertiary } \\
\text { and } \\
\text { Quaternary }\end{array}$ & $\begin{array}{l}\text { Subaerial exposure of exhumed } \\
\text { Edwards Limestone within the } \\
\text { Balcones fault zone. Water table } \\
\text { lies from near land surface to } \\
\text { more than } 200 \text { feet below land } \\
\text { surface. }\end{array}$ & $\begin{array}{l}\text { Short periods of rapid } \\
\text { uplift and interspersed, } \\
\text { extended periods of ero- } \\
\text { sion and sedimentation. }\end{array}$ & $\begin{array}{l}\text { Extensive development of sink- } \\
\text { holes during wet periods. Uplift } \\
\text { disrupted the development of } \\
\text { cavernous systems and associ- } \\
\text { ated sinkholes. Little active } \\
\text { sinkhole development during } \\
\text { Holocene. During periods of } \\
\text { rapid uplift, streams incise their } \\
\text { channels, and discharge points } \\
\text { of cavernous aquifer system are } \\
\text { stranded above the lowered } \\
\text { stream level. Cavernous poros- } \\
\text { ity systems are developed } \\
\text { within the Edwards Limestone } \\
\text { near the water table and in the } \\
\text { vadose zone. Rapid circulation } \\
\text { of ground water through the } \\
\text { cavernous networks. (Most of } \\
\text { the flow within the aquifer is } \\
\text { controlled by this network.) }\end{array}$ & Same as above. & $\begin{array}{l}\text { Water-yielding openings } \\
\text { that drain by gravity are } \\
\text { almost entirely of sec- } \\
\text { ondary origin. Water } \\
\text { within rock matrix will } \\
\text { not drain or will drain } \\
\text { very slowly by gravity. } \\
\text { Therefore, the effective } \\
\text { porosity within the } \\
\text { unconfined area is less } \\
\text { than that of the confined } \\
\text { zone of the aquifer. }\end{array}$ \\
\hline
\end{tabular}

types of dolomite crystals include: (1) dolomitic rhombs with distinct zoning bands paralleling the crystal faces; (2) turbid, "dusty looking," fine-grained dolomite rhombs; and (3) dolomite rhombs having hollow centers (Small and Maclay, 1982.) The latter two types of rhombs are associated with supratidal features (Ruth G. Deike, U.S. Geological Survey, oral commun., 1979). Dolomite in micrite ranges from scattered "floating" rhombs to tightly packed rhombs with little or none of the original carbonate mud remaining and the original rock texture obliterated.

The relative ease of ground-water circulation in the aquifer is shown by the color of the rocks through which the water flows. The calcitic, strongly crystal- lized, dense rocks in the freshwater parts of the aquifer are light buff to white. These rocks contain little pyrite and no gypsum. In those parts of the aquifer where water circulation is slow, the color of the rocks typically is a darker gray or brown.

Four late diagenetic and geologic environments affecting porosity and permeability development in the Edwards aquifer are recognized: (1) the deeply buried part of the aquifer containing saline water, (2) the shallow buried part of the aquifer containing moderately saline water, (3) the confined part of the aquifer containing freshwater of meteoric origin, and (4) the unconfined cavernous part of the aquifer containing a rapid circulating freshwater-flow system. 
Porosity and permeability have been affected in the deeply buried part of the aquifer containing saline water, with chloride the dominant ion. Generally, the dolomite is substantially more permeable than limestone because of its sucrosic properties. This has been demonstrated by laboratory tests of rock cores, in which pore-size distributions and associated permeabilities have been examined and documented (Maclay and Small, 1976; Small and Maclay, 1982). The permeability of the deeply buried rock is minimal when compared with that of the succeeding diagenetic environments. The enhancement of porosity essentially was halted during the deep burial stage, except for the minimal effect of stylolitization.

The porosity and permeability in the shallow, confined part of the aquifer containing moderately saline water of sulfate type are related to openings associated with the unconformity between the Georgetown Formation (table 1) and Edwards Group and to open fractures along faults that provide a vertical passageway for water to move between zones in the Edwards. The permeable paleokarst zone associated with the unconformity provides a passage where water can move from the freshwater part of the aquifer to the saline-water part. The mixing of water could enhance porosity and permeability development along the unconformity and especially in those areas such as grabens or buried valleys containing karst features, where circulation might be most active.

The porosity and permeability development in the confined part of the aquifer containing freshwater differs from that of other environments. The dolomitic rocks of this part of the Edwards aquifer have been selectively leached by an enormous volume of circulating ground water of bicarbonate type with a large ratio of dissolved calcium concentration to dissolved magnesium concentration that is not in equilibrium with the chemical composition of dolomite. The resulting dedolomitization is active near the transition zone between freshwater and saline water, and consequently, the process has increased the secondary porosity in rocks near that zone as evidenced by mineralogy, water chemistry, and petrography (Ruth G. Deike, U.S. Geological Survey, oral commun., 1979). Also, large, cavernous voids have been observed through the use of a borehole televiewer at a test hole penetrating the transition zone immediately east of downtown San Antonio (Pavlicek and others, 1987).

The latest stage of development of porosity and permeability in the unconfined part of the aquifer involved circulating fresh ground water in fracture systems. This resulted in cavernous openings that differ from the stratigraphically and diagenetically controlled openings of the confined aquifer. Included in the cavernous system are inclined and vertical caves within the unsaturated zone and horizontal caves near the water table. The water table is related to the base level of present perennial streams and to the extent of recent uplift. In this hydrogeologic environment, the stratigraphic control on the development of porosity and permeability in dolomitic strata is substantially less, and the fracture control is substantially more important. The meteoric water dissolves rocks along inclined fractures which lead to the water table. This development of cavernous porosity has been interrupted intermittently, when uplift of the Edwards Plateau caused springs to form at lower altitudes in the Balcones fault zone.

Rocks of the Maverick basin (fig. 2) are the least permeable and have little porosity. Permeability increases somewhat toward the Devils River trend, where shallow-water conditions resulted in the deposition of grainstone and wackestone with greater interparticle porosity. Much of the secondary permeability results from small, open, sparsely distributed, hair-line fractures.

Rocks of the Devils River trend (fig. 2) are more permeable than rocks of the Maverick basin but less permeable than rocks of the San Marcos platform. During Cretaceous time, they were exposed, and local unconformities were developed in association with the karstification of underlying carbonates. Dolomitization and karstification of the carbonate rocks near these unconformities enhanced the permeability of the rocks in the Devils River trend.

Rocks of the San Marcos platform are the most permeable. These rocks are extensively dolomitized, and the resulting sucrosic property increases permeability. The rocks containing this type of porosity are extensively dissolutioned in the freshwater part of the confined Edwards aquifer. Secondary porosity is well developed in the tidal deposits that contained leached dolomitized burrows and, locally, collapse breccia.

An interpretation of the distribution of permeabilities by stratigraphic units of the Edwards aquifer and its confining units is shown in figure 11. The relative permeabilities (fig. 11) are approximations based on field observations, stratigraphic studies by Rose (1972), and data from test-drilling and geophysicallogging programs (Maclay and Small, 1983). These 


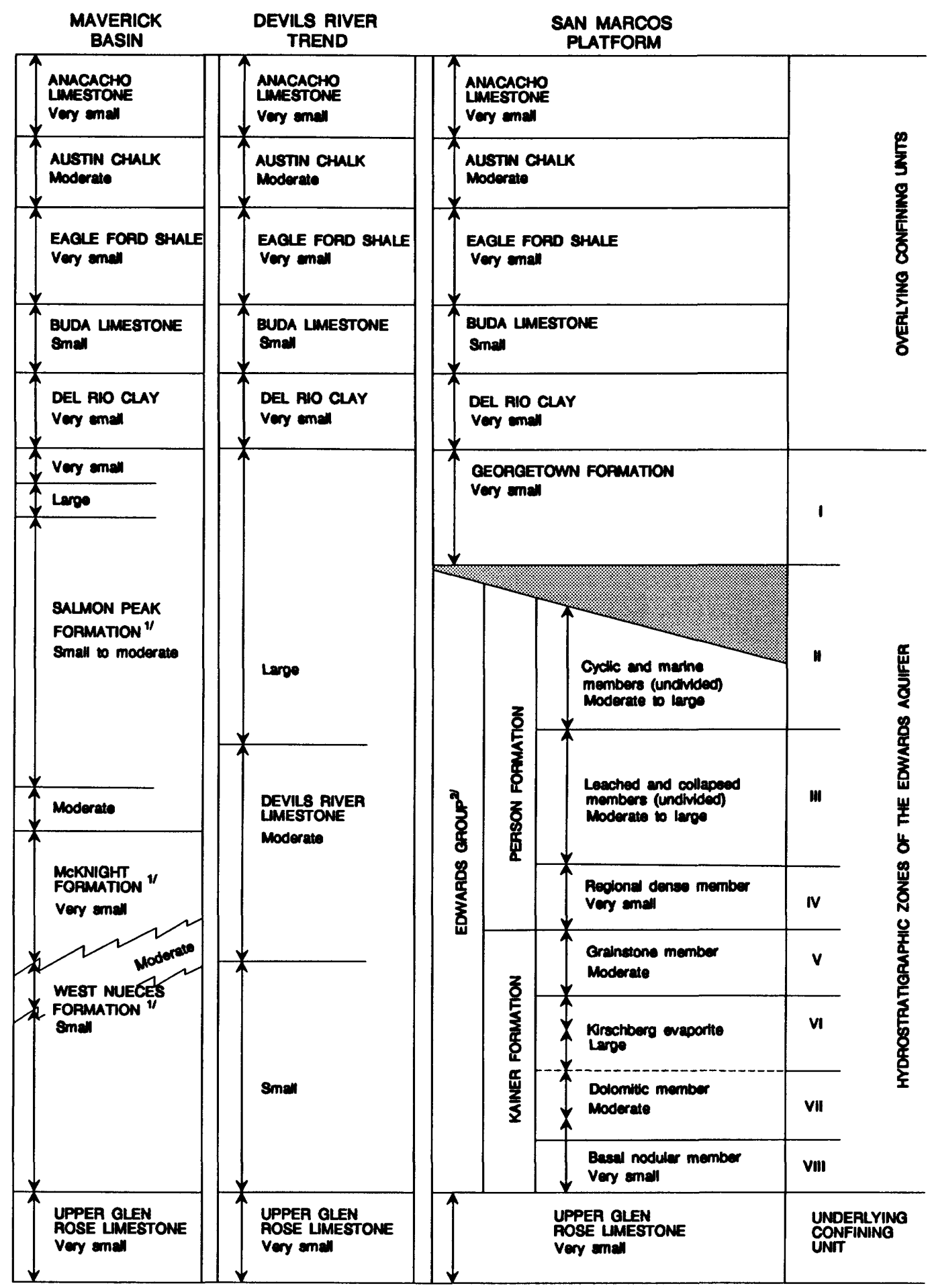

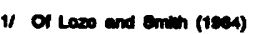

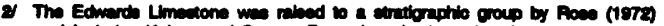

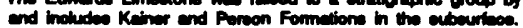

ABSENT OR HIATUS

Figure 11. Relative permeability of hydrostratigraphic zones within and adjacent to the Edwards aquifer in the San Antonio area, Texas. (Modified from Rose, 1972.) 
Table 4. Porosity and permeability features of the hydrostratigraphic zones in the Edwards aquifer within the San Marcos platform in the San Antonio area, Texas ${ }^{1}$

$[<$, less than]

\begin{tabular}{|c|c|c|c|}
\hline Hydrostratigraphic zone ${ }^{2}$ & $\begin{array}{l}\text { Total porosity } \\
\text { (percent) }\end{array}$ & Relative matrix permeability 4 & Fractures \\
\hline I & $<5$ & Very small & Few, closed \\
\hline II & $5-15$ & Moderate to large & Many, open \\
\hline III & $5-20$ & Moderate to large & Many, open \\
\hline IV & $<5$ & Very small & Closed \\
\hline V & $5-15$ & Moderate & Few, open \\
\hline VI & $5-25$ & Large & Undetermined \\
\hline VII & $5-20$ & Moderate & Many, open \\
\hline VIII & $<10$ & Very small & Few, open \\
\hline
\end{tabular}

\footnotetext{
${ }^{1}$ Modified from Maclay and Small (1984).

2 Correlation with stratigraphic units shown in figure 11 .

${ }^{3}$ Based on visual examination of cores.

${ }^{4}$ Matrix permeability refers to permeability related to interstices, associated with the bulk of the rock, and not to permeability related to cavernous openings or fractures.
}

permeabilities apply to the confined part of the Edwards aquifer and might not be strictly applicable to the unconfined part of the aquifer. Permeability of the unconfined part of the aquifer has developed mainly along fractures that are enlarged solutionally near the water table.

The Edwards aquifer within the San Marcos platform consists of eight hydrostratigraphic zones (figs. 11, 12; table 4). Highly permeable intervals are variably distributed throughout zones II, III, and VI. The most permeable parts of these zones are in honeycombed rock formed by large rudistid molds, in irregular openings in burrowed tidal wackestone, and in collapse breccia in supratidal deposits. The most porous rock is leached or poorly cemented grainstone, mostly in zones II, III, V, VI, and VII (table 4).

Although the grainstone has large porosity, it has relatively small permeability resulting from the small degree of interconnection between pores. Hydrostratigraphic zones I, IV, and VIII have very small permeability and small effective porosity. Identification of the zones is shown by the various types of geophysical logs (fig. 12). The two normal resistivity curves and the gamma curve are used mainly for geologic correlation, whereas the neutron and gamma-gamma logs are used for porosity determinations. The caliper log provides qualitative information on lithology and permeability.
The geophysical logs and core-hole data in the Devils River trend did not indicate that the Edwards aquifer could be subdivided readily into hydrostratigraphic zones. However, the permeability tends to increase in the upward direction in association with cavernous zones.

The stratigraphy of the Edwards aquifer within the Maverick basin is shown by the geophysical logs in figure 13. The Salmon Peak Formation, which is the upper subdivision of the aquifer in the Maverick basin, is the most porous and permeable subdivision of the aquifer on the basis of interpretation of the geophysical logs and core data. Cavernous porosity in the upper part of the Salmon Peak Formation was indicated by an increased hole diameter detected by the caliper log.

\section{Hydraulic Properties}

The large transmissivity of the Edwards aquifer is indicated by the hundreds of highly productive wells throughout the San Antonio area. Many of the wells yield more than $1,000 \mathrm{gal} / \mathrm{min}$ of water with drawdown of only a few feet. The large transmissivity of the confined aquifer is further indicated by small hydraulic gradients, large spring discharges, and relatively uniform quality and temperature of water throughout the aquifer. The large volume of available water in storage 


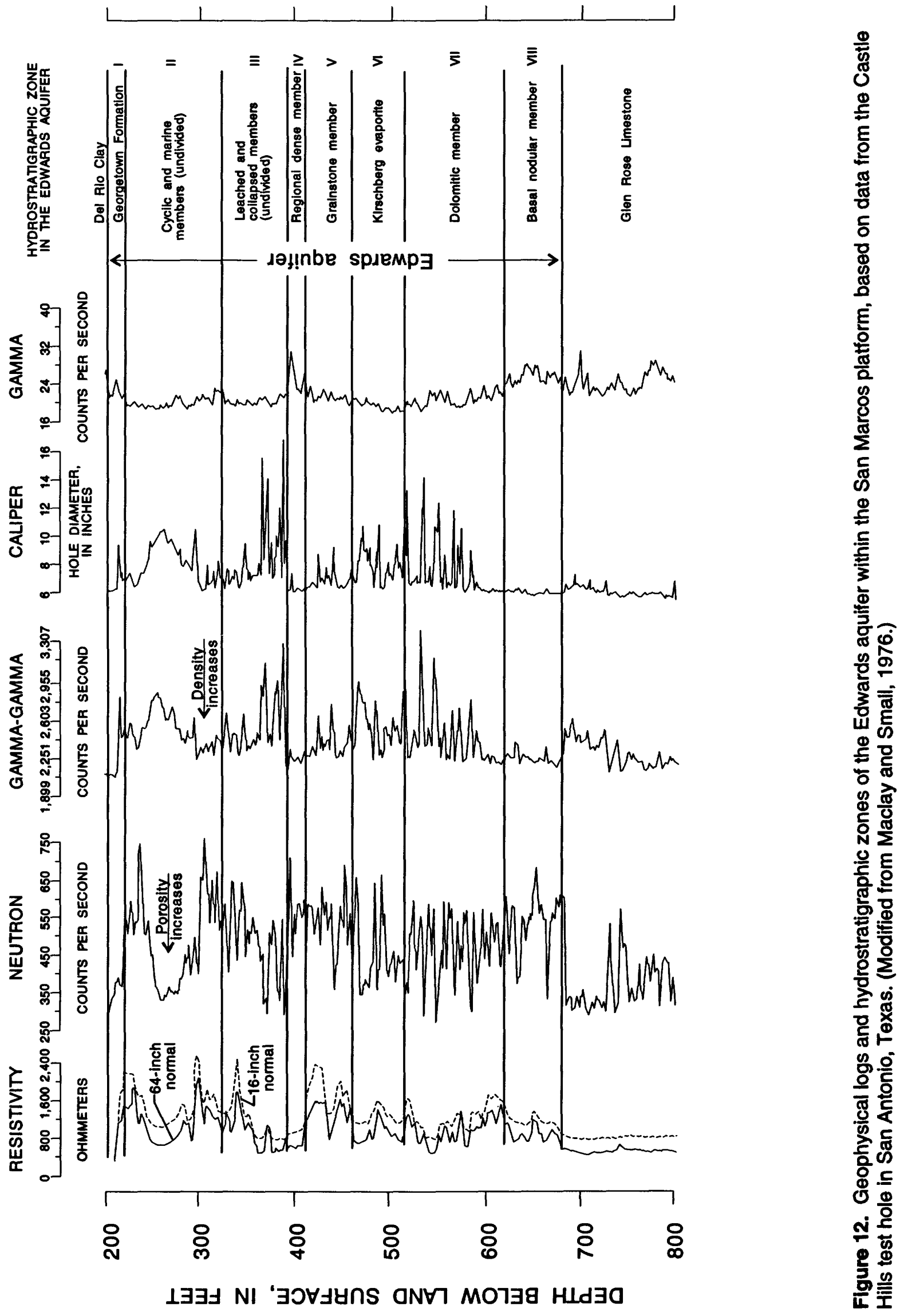




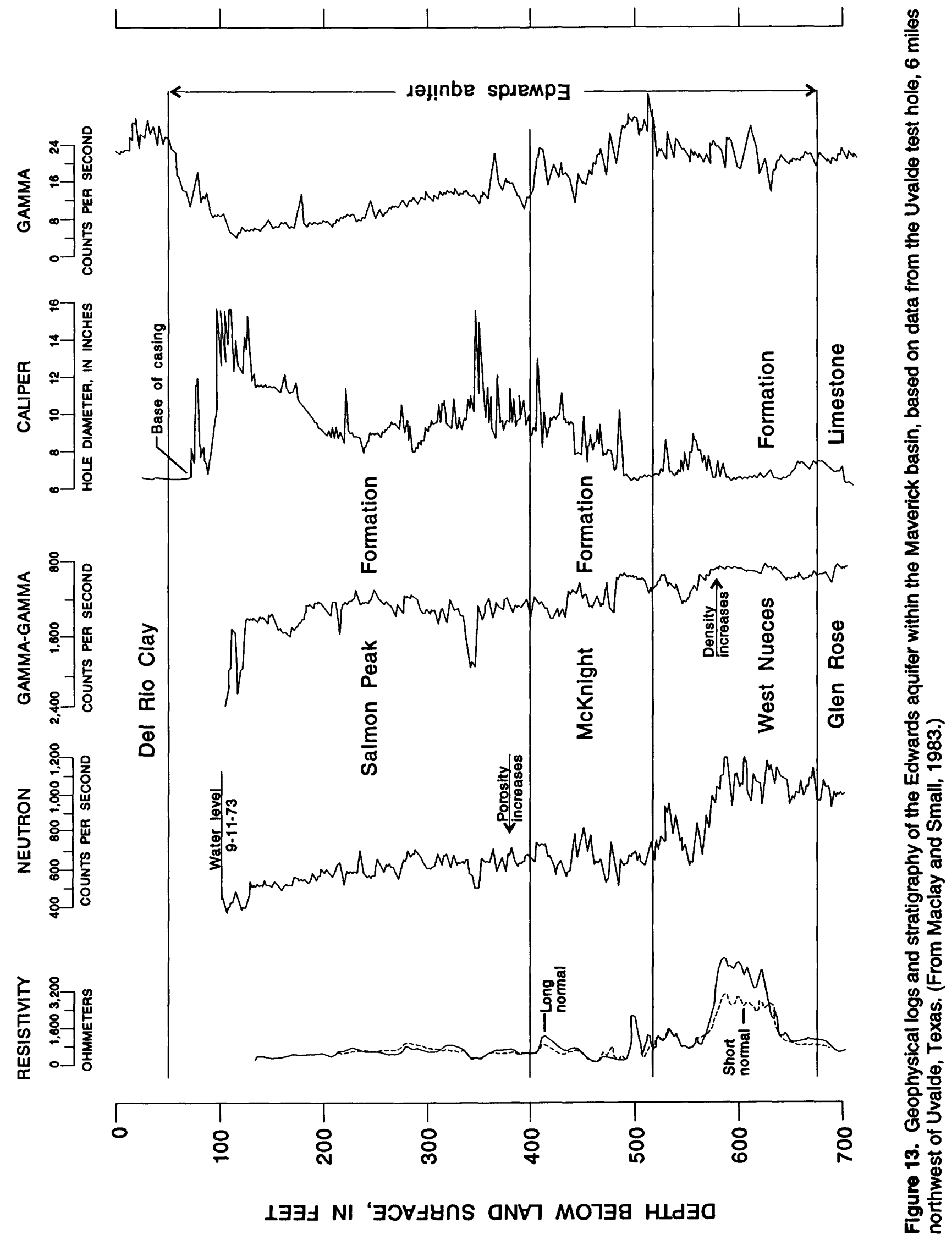


is indicated by large sustained flows at the major springs and by large pumpage.

Flowing wells that discharge more than 10,000 $\mathrm{gal} / \mathrm{mm}$ have been drilled in the city of San Antonio. In Bexar County, live, blind catfish have been netted from the water discharging from flowing wells with depths of approximately 1,500 ft (Longley, 1981, p. 1-15). These wells are located near the transition zone between the freshwater and saline-water zones of the aquifer at distances of more than $15 \mathrm{mi}$ from the unconfined part of the aquifer. The presence of the catfish at these wells indicates that interconnected cavernous openings exist at great depths in the aquifer. These cavernous openings might be associated with segments of valley systems of a paleokarst developed during Cretaceous time on the uplifted San Marcos arch or could be the result of in situ dissolution near the transition zone.

Aquifer-test data for determining the hydraulic properties of the Edwards aquifer have been compiled and summarized by Maclay, Small, and Rettman (1980). That report presents data on specific capacities, well yields, aquifer tests, and regional water-level fluctuations caused by well withdrawals and recharge from a major storm. Major products of a study by Klemt and others (1979), who prepared a digital ground-waterflow model of the Edwards aquifer for management purposes, include maps showing storage coefficient, transmissivity, and anisotropy. Garza (1968, p. 31) estimated the transmissivity in the confined part of the aquifer in the San Antonio area to be $1,000,000$ to $2,000,000 \mathrm{ft}^{2} / \mathrm{d}$. Estimates of the transmissivity of the aquifer in subareas of the San Antonio area were based on geologic, hydrologic, and hydrochemical information (Maclay and Small, 1984, p. 48-53).

The distribution of transmissivity, on the basis of available geologic, hydrochemical, and hydrologic information, is given by Maclay and Land (1988) and shown in plate 7 . The relative transmissivities were first estimated by subarea on the basis of hydrogeologic characteristics of the rocks. Quantitative values then were derived during calibration of a digital groundwater-flow model. The largest transmissivity was determined to be more than $4,300,000 \mathrm{ft}^{2} / \mathrm{d}$, in Comal County near Comal Springs, and the smallest was 130 $\mathrm{ft}^{2} / \mathrm{d}$, in the saline-water zone (Maclay and Land, 1988, p. A-27). The transmissivity determined throughout most of the freshwater zone of the confined aquifer ranged from 430,000 to $2,200,000 \mathrm{ft}^{2} / \mathrm{d}$ and in the recharge area generally was less than $430,000 \mathrm{ft}^{2} / \mathrm{d}$.
The ratio of anisotropy (ratio of maximum to minimum values of directional transmissivity) derived by digital-model analysis (Maclay and Land, 1988) is shown in plate 8 . The regional maximum directional transmissivity is aligned along barrier faults where the aquifer is completely or partially separated. Determined anisotropy ratios range from 0.0:1 to 1:1 (Maclay and Land, 1988, p. A-34).

The specific yield of the unconfined Edwards aquifer is not accurately known, but it probably ranges from less than 0.05 to 0.20 depending principally on the textural rock types (Maclay and Small, 1976). The storage coefficient of the confined Edwards aquifer is estimated to range from $1 \times 10^{-4}$ to $1 \times 10^{-5}$, depending on the porosity and thickness of the aquifer (Maclay and Small, 1984).

\section{HYDROLOGY OF THE EDWARDS AQUIFER}

\section{Climate, Precipitation and Effects, and Evapotranspiration}

The climate of the San Antonio area generally is mild, with long, hot summers and short, cool winters. Freezing temperatures and snowfalls occur occasionally and result from the rapid influx of cold highpressure continental air masses from the north. The altitude of the area ranges from about $2,300 \mathrm{ft}$ above sea level in the northwestern part of the Edwards aquifer catchment area to about $600 \mathrm{ft}$ above sea level near San Marcos in the Gulf Coastal Plain (pl. 1). Summer and winter temperatures generally are several degrees cooler at the higher altitudes. Average annual temperatures range from about $65^{\circ} \mathrm{F}$ on the Edwards Plateau to about $69^{\circ} \mathrm{F}$ on the Gulf Coastal Plain. Summer temperatures average about $80^{\circ} \mathrm{F}$, and winter temperatures average less than $60^{\circ} \mathrm{F}$.

Average annual precipitation in the San Antonio area varied from about 21 in. in the western part to about 34 in. in the eastern part during 1934-89. Annual precipitation at Brackettville in the western part of the San Antonio area ranged between 8 and 45 in., and annual precipitation at San Marcos in the eastern part ranged between 13 and 52 in. for 1934-89. Annual precipitation in San Antonio averages about 29 in. (Office of State Climatologist, 1987). Most precipitation results from intense summer thunderstorms, some of which have produced more than $10 \mathrm{in}$. of precipitation within 24 hours, causing severe damage from local 
flooding. Major hurricanes moving inland from the Gulf of Mexico to the Edwards Plateau have occurred infrequently; however, these major storms have produced large quantities of precipitation throughout extensive areas of the Edwards Plateau. Runoff from these infrequent storms has caused extensive damage to the natural vegetation, principally "bald cypress" trees that line the banks of some streams.

Periods of excessive precipitation followed by extended droughts are characteristic of the area and cause major hydrologic effects. The frequency and length of these periods are irregular. The most severe drought on record occurred during 1950-56, when the decline of water levels in the Edwards aquifer led to substantially reduced springflow. In the summer of 1956, after several years of slowly declining flow, Comal Springs ceased to flow. However, during late 1956 and 1957, major drought-breaking storms recharged the aquifer, and since then, Comal Springs have had continuous flow. In the middle 1970's to late 1980 's, the region had greater-than-average precipitation; however, dry years (such as 1984 and 1988) have resulted in rapid declines of water levels in the Edwards aquifer and less-than-average springflow. These natural effects were magnified by an increased rate of pumping from wells during recent years.

Evaporation is a continuous process, but the rates of evaporation vary considerably, depending on temperature and other climatic conditions. Mean annual pan-evaporation rates range from about $90 \mathrm{in}$. in the more arid western part of the area to about 75 in. in the more humid eastern part.

Evapotranspiration, as a percentage of the total precipitation, is slightly larger in the western part of the San Antonio area, although total evapotranspiration is substantially larger in the eastern part. About 85 to 90 percent of the precipitation that falls in the area is lost through evapotranspiration.

\section{Flow System}

The ground-water-flow system of the Edwards aquifer in the San Antonio area typically includes the following components, from north to south: (1) a catchment area on the Edwards Plateau on the north where the rocks of the Edwards aquifer are exposed and receive direct recharge to the water table; (2) an intervening middle area of exposed confining beds (Glen Rose Limestone) crossed by streams draining the Edwards Plateau and separating the Edwards aquifer on the Edwards Plateau from the Edwards aquifer in the Balcones fault zone. (In some places this intervening area of Glen Rose Limestone is not exposed, and the Edwards Group on the Edwards Plateau is laterally connected to the Edwards Group in the Balcones fault zone.); (3) a major recharge area to the south paralleling the Balcones fault zone where these streams lose flow directly into the faulted, highly permeable, unconfined Edwards aquifer; and (4) farther south, the confined Edwards aquifer consisting of the freshwater and saline-water zones. Ground-water flow through this system averaged about 635,500 acre-ft of water annually from the middle 1930's to the late 1980's (Reeves and Ozuna, 1986).

In the Edwards Plateau, meteoric water flows into the unconfined Edwards aquifer after infiltrating a karstic limestone cap and enters the saturated zone at depths commonly in excess of several hundred feet below land surface. Within the saturated zone, the water flows toward the irregular escarpments of the rim of the Plateau where it is discharged by springs emerging on the walls of reentrant valleys at the contact of the Edwards aquifer with the underlying Glen Rose Limestone.

In the Balcones fault zone, the Edwards aquifer receives infiltration losses from streams crossing the Edwards outcrop and receives water from direct precipitation on the outcrop. Flow in the aquifer is regionally toward large artesian springs emerging along faults cutting the confined aquifer, and a substantial part of the total flow is toward the many wells that are pumped or have natural flow. Some outflow occurs from the confined Edwards aquifer in the Balcones fault zone into the saline-water zone of the Edwards aquifer located farther downdip. Small quantities of saline water are discharged by leakage to overlying confining units, or by underflow returning to the freshwater zone of the Edwards aquifer near the Colorado River where the freshwater zone of the aquifer in the Balcones fault zone is only $4 \mathrm{mi}$ wide (Baker and others, 1986).

\section{Regional Circulation Patterns}

Major features of the regional flow system are shown by a potentiometric-surface map of the Edwards aquifer in the San Antonio area (pl. 9). This map is based on ground-water levels measured during the winter of 1973, which generally conform to the current regional system. 
Water entering the Edwards aquifer in the recharge area in the Balcones fault zone moves generally in a southeasterly direction from the unconfined to the confined parts of the aquifer. In the confined aquifer, the water moves under low hydraulic gradients through fractured, highly transmissive, cavernous limestone toward the east and northeast where it is discharged through springs and wells.

An extensive, compartmentalized ground-waterflow pattern exists in the Balcones fault zone. The width of the freshwater zone of the confined aquifer in the Balcones fault zone from eastern Uvalde County to Bexar County is much greater than in other confined areas of freshwater in the Balcones fault zone. The inflow of freshwater moves along a path that extends substantially downdip from a structural gap in barrier faults in Uvalde County. Ground-water flow in southeastern Uvalde and Medina Counties is diverted eastward toward the artesian springs at lower altitudes in the eastern part of the San Antonio area. The flowpaths are controlled laterally by barrier faults that locally compartmentalize the aquifer, especially toward the eastern part of the San Antonio area. These barrier faults in the confined aquifer function somewhat as subsurface weirs that direct flow northeastward.

A circulation pattern in the downdip, salinewater zone of the Edwards aquifer is interpreted from geologic and hydrochemical information (Maclay, Rettman, and Small, 1980; Clement and Sharp, 1988). A small flux of fresh ground water enters the salinewater zone in the western part of the study area. Locally, barrier faults divert water toward the salinewater zone. This freshwater gradually becomes saline by dissolving soluble minerals present in the rocks and by mixing with the saline-water zone of the aquifer.

Circulation in the saline-water zone of the Edwards aquifer is sluggish because of lower transmissivity and lower hydraulic gradient. However, the sedimentary features and structure of the rocks in the saline-water zone substantially affect the pattern of ground-water circulation in the zone. Particularly important to ground-water flow is the permeable zone near the unconformity between the Georgetown Formation and Edwards Group and the northeasterly orientation of structural grabens in the saline-water zone of the Edwards aquifer. Some water in the saline-water zone might discharge upward along faults or through shallow Edwards oil wells in Guadalupe and Caldwell Counties. At the Luling oil field in Caldwell County, water with about $14,000 \mathrm{mg} / \mathrm{L}$ dissolved solids is being discharged from oil wells tapping permeable vuggy zones near the contact between the Georgetown Formation and Edwards Group. The volume of saline water produced in this oil field was about $300,000 \mathrm{bbl} / \mathrm{d}$ (12.6 Mgal/d) on July 1, 1957 (Hendy, 1957). At the Salt Flat oil field in Caldwell County, saline water naturally might be discharging upward from the Edwards aquifer, and possibly from the Austin Chalk, into a salt marsh at the surface. In the eastern part of the San Antonio area, small flows from the saline-water zone of the aquifer might be entering the freshwater zone of the aquifer-a possibility indicated by chemical quality changes in the flow of Barton Springs (Baker and others, 1986).

Small quantities of fluids derived from compacting sediments in the geopressured area of the Gulf Coastal Plain near the buried Stuart City reef trend probably are moving slowly updip into the permeable zones in the Edwards aquifer. These fluids of nonmeteoric origin are driven by large hydraulic heads in the geopressured zone. Basically, the fluids are derived from episodic fluid breakouts through the rupture of seals that confine fluids at pressures substantially greater than normal hydrostatic pressures (Hunt, 1990).

\section{Geologic Controis on Local Ground-Water Flow}

Discontinuities in the aquifer resulting from faulting are common. Major fault discontinuities create internal boundaries that locally obstruct lateral flow and produce complex flow patterns in the aquifer. The analysis of local ground-water flow in the Edwards aquifer presented here uses information on the stratigraphy and geometry of the faulted aquifer framework. Some of the interpretations are supported by a numerical simulation of the aquifer's flow system as discussed in the next section.

Barrier faults that restrict lateral flow of ground water in the aquifer exist where fault displacements have juxtaposed permeable strata opposite relatively impermeable strata. Hydraulic connection varies across a fault depending on the fault's vertical displacement. Also, rotation relative to a fault plane can produce varying degrees of hydraulic connection along the fault plane. Schematic diagrams that illustrate the character of the fault displacements are shown in figure 14.

Small (1986) presented a series of hydrogeologic sections extending from the Edwards outcrop downdip to the saline-water zone. Four of these sections 

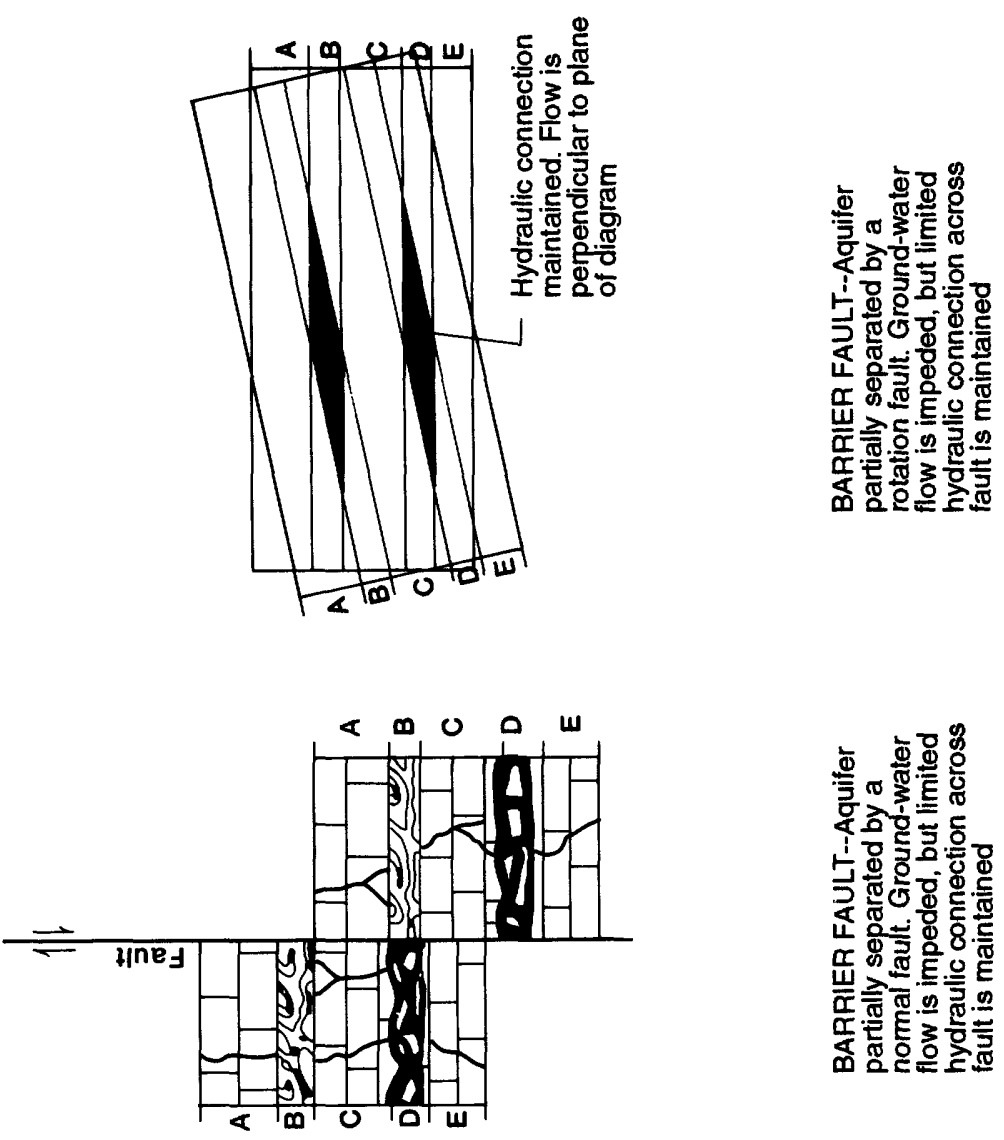

只
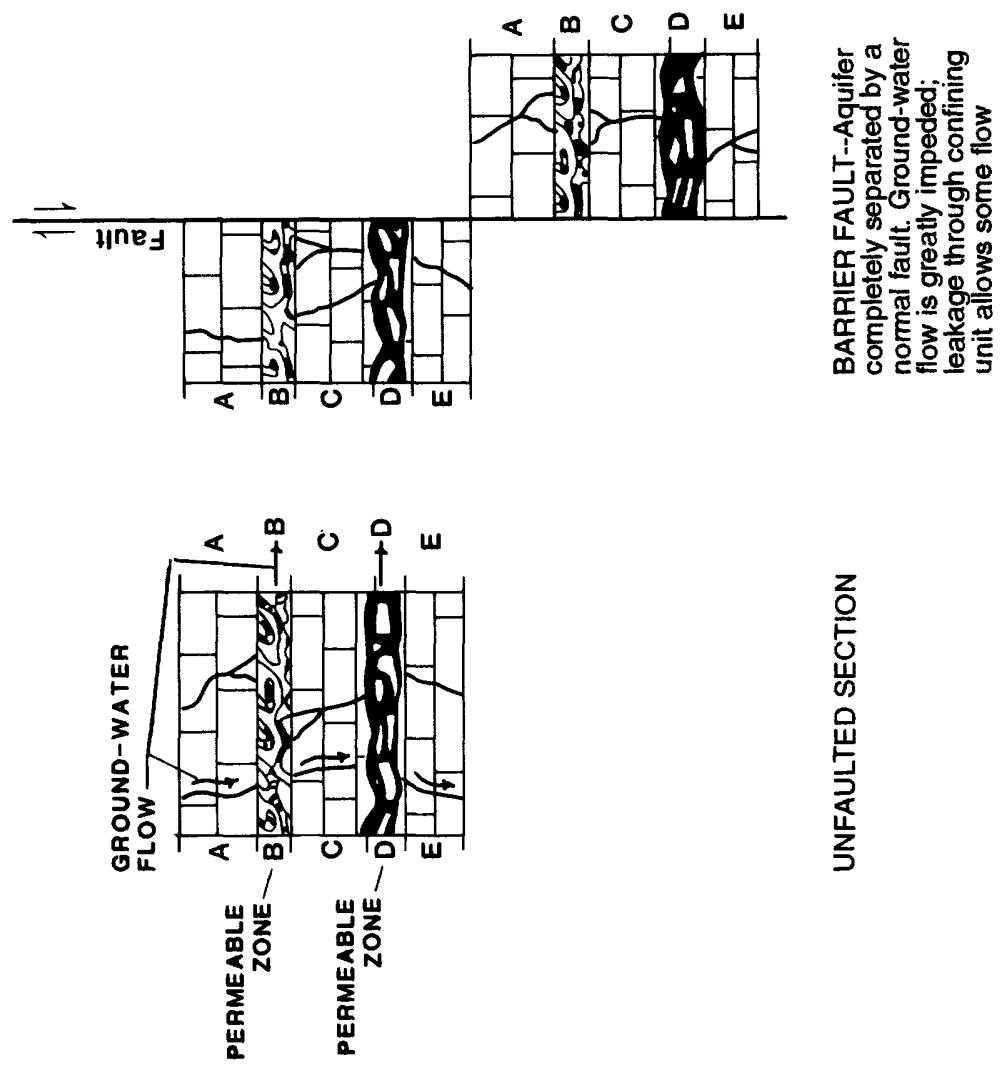

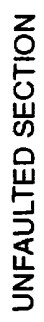


(figs. 6-9) show the variation in vertical displacement of faults. The percent of aquifer thickness displaced by faulting throughout the San Antonio area (fig. 15) was determined using the complete set of hydrogeologic sections. A potential barrier could exist where the vertical displacement is more than 50 percent of the thickness of the aquifer. Such displacement can put the most permeable zones opposite relatively impermeable zones, thus reducing ground-water flow across the fault and causing flow to be diverted parallel to the fault plane.

The effect on the potentiometric surface of the Edwards aquifer caused by faults that vertically displace the complete thickness of the aquifer is shown in plate 9. The most apparent effect is in northern Medina County where the potentiometric contours are controlled by the Medina Lake fault. Holt (1959) has mapped the potentiometric surface of the aquifer in Medina County at a larger scale than that shown in plate 9 , and his map shows as much as $90 \mathrm{ft}$ of head difference across faults in northeastern Medina County. The direction of ground-water flow in the Edwards aquifer in this area is southwestward, approximately along the strike of the faults. Here, these faults, which have totally displaced the aquifer, prevent ground water from moving directly downdip into the confined part of the aquifer. However, in western Medina County, substantial obstruction of ground-water flow, by the faults, to the deeper part of the confined aquifer is not evident.

Other faults that vertically separate the aquifer are in the deeper parts of the confined zone; however, documentation of their effect on flow patterns is difficult because of the lack of wells available for waterlevel measurement. Detection of fault barriers by measurement of water levels also is difficult because the large transmissivity of the confined zone causes head differences to be small across faults. However, in the unconfined part of the aquifer in Comal County, where transmissivity is smaller, head differences of 6 to $26 \mathrm{ft}$ across segments of major faults were reported by George (1952, p. 52).

Some faults can serve as conduits for lateral and vertical flow of water. For example, faulting can position a deeper or shallower formation that is water yielding opposite the Edwards aquifer and facilitate an exchange of water across the fault plane. Also, the fault plane itself, which commonly is fractured and has large permeability in hard-rock strata like the Edwards, can function as a conduit for vertical flow of water from underlying and overlying water-yielding formations.

\section{Flow and Storage Concepts Based on Computer Simulation}

To investigate the effects of the faults on groundwater flow, a digital model of the ground-water-flow system of the Edwards aquifer in the San Antonio area was developed (Maclay and Land, 1988). The computer code for the digital model was written by Trescott and others (1976) and uses a two-dimensional, finitedifference approach. The hydrologic conditions for the simulations were based on data beginning in 1972, when recharge approximately equalled discharge. An assumption was made that steady-state conditions existed in the Edwards aquifer during 1972, thus allowing the use of a steady-state model. The modeled area, which was divided into grid cells based on rows and columns, was about $75 \mathrm{mi}$ wide and $280 \mathrm{mi}$ long and included all of the San Antonio area. Row widths ranged from 0.79 to $6.31 \mathrm{mi}$, and column widths ranged from 1.18 to $3.95 \mathrm{mi}$. Discharge from Comal and San Marcos Springs was simulated on the basis of specification of constant heads corresponding to groundwater levels in the area. The initial distribution of transmissivity was based on a delineation of relative transmissivities in 20 subareas by Maclay and Small (1984). The model-determined flow vectors from the calibrated model are shown in figure 16. These vectors are the resultant component of unit discharge (cubic foot per second per foot of aquifer width) across boundaries of a given cell.

In northern Medina County, model results show that flow is diverted to the southwest by major barrier faults. The structural horst east of Uvalde diverts ground-water flow eastward from this area in Uvalde County. A rhomboid-shaped horst in the confined zone of the aquifer area in central Bexar County marks the location of two major intermittent artesian springs at a restriction along a flowpath. Where permeable strata on the upthrown side are opposite less permeable strata on the downthrown side, limited ground-water flow crosses the fault. The modelling analysis indicates that converging barrier faults "channel" water toward major springs, thereby affecting spring discharge.

\section{Flow and Storage Units}

Changes in water levels in the unconfined zone of the Edwards aquifer represent substantial changes in 


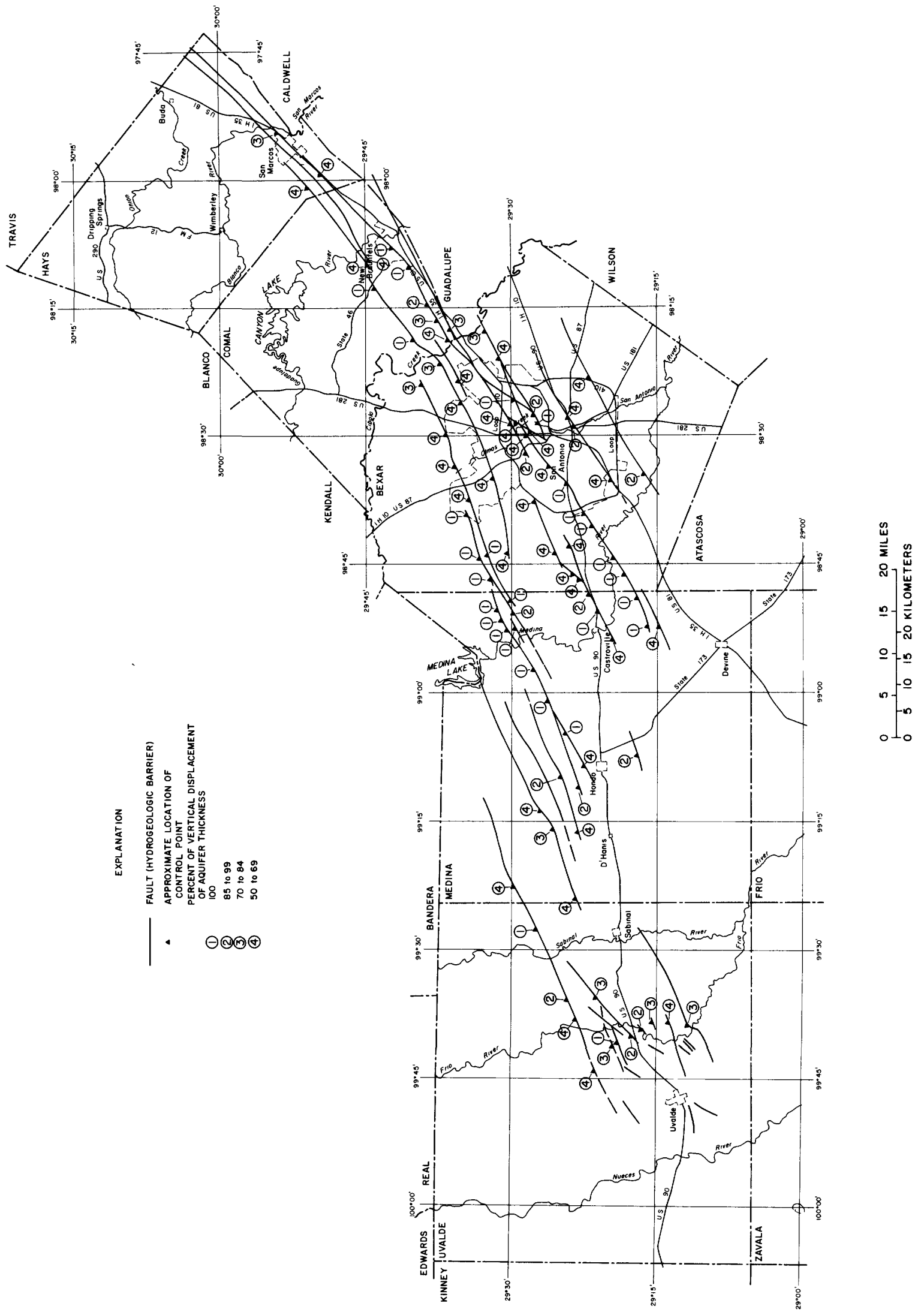

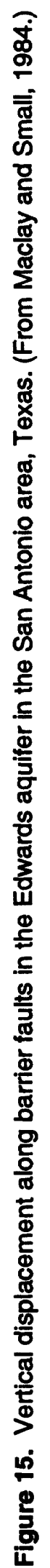




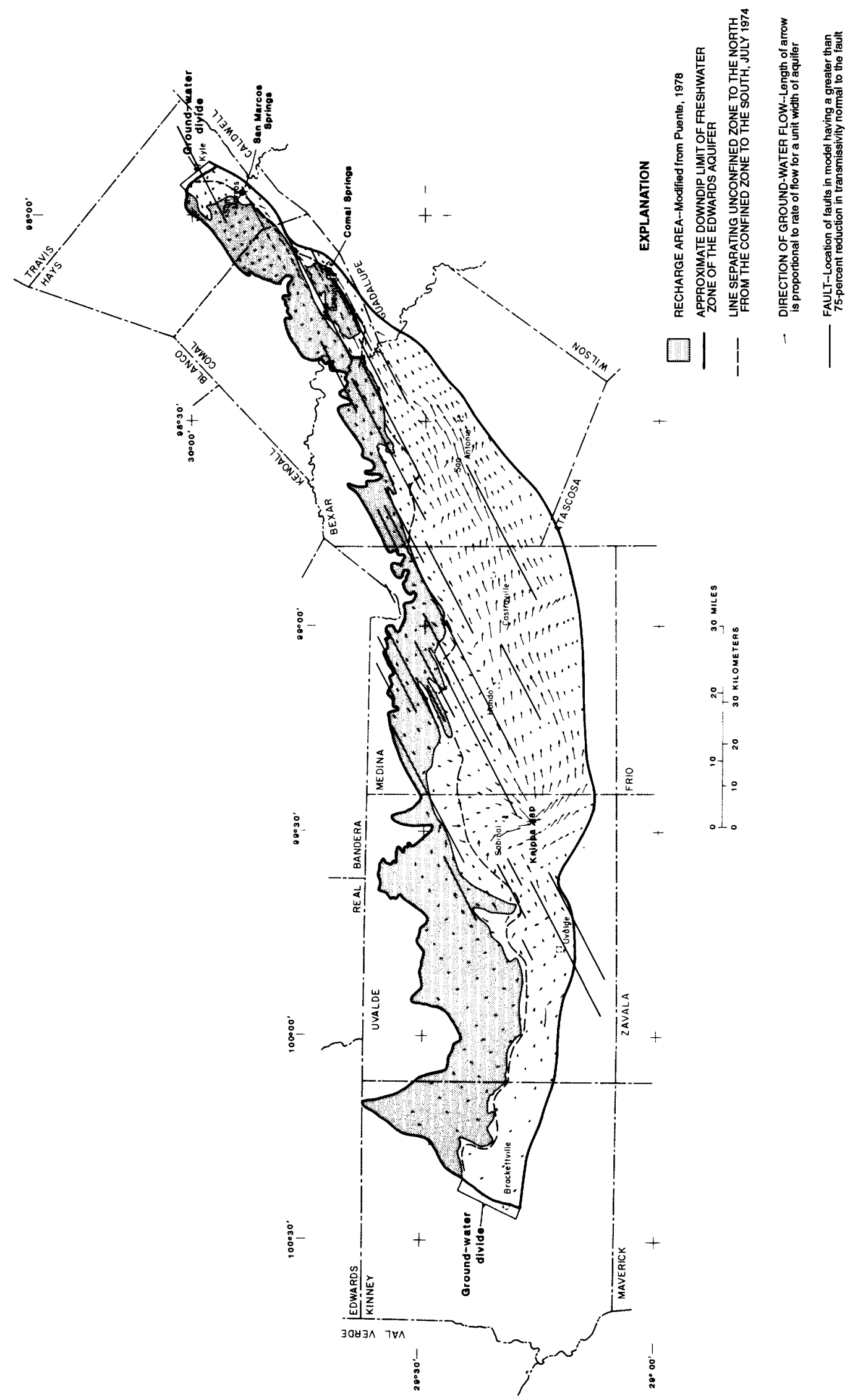


the volume of water stored in the total aquifer, whereas comparable changes in water levels in the confined zone represent only small changes. Because the area of the unconfined zone represents about 30 percent of the total aquifer, most of the water released from storage for a given water-level decline comes from this zone.

The quantity of water temporarily retained in storage in the unconfined zone is affected strongly by the barrier faults previously discussed. These faults obstruct the flow of ground water from the unconfined zone to the confined zone. Because of the obstructions, water movement from the unconfined zone to the confined zone follows an extended flowpath causing water to remain in the unconfined zone for longer periods of time.

Simulation by the digital model indicated that four subareas of the unconfined zone tended to function as independent storage units because of faults. These storage units are referred to as western, western Medina, eastern Medina, and eastern. The division between these units is influenced strongly by major faults, narrowing of the recharge area, and stream basin boundaries. These storage units are shown in plate 10 and described in table 5. They are delineated with the aid of the flow-vector map (fig. 16), maps of the unconfined zone and recharge area, and location of the major barrier faults.

Simulation identified four generally independent ground-water-flow units-western-southern, southcentral, north-central, and eastern. For purposes of this report, a flow unit of the Edwards aquifer is defined as an area of the aquifer that includes a storage unit and the area of the flowpaths that transmit water from this storage unit to major points of discharge. The flow units are shown in plate 10 and described in table 6. They were delineated primarily with the aid of the flow-vector map (fig. 16) and the locations of barrier faults and storage units. Some interchange of ground water from one flow unit to another probably occurs if the potentiometric surface fluctuates substantially. The flow units probably do not vary greatly when water levels remain within their historical range because of the internal boundaries of the aquifer and the fixed locations and stable rates of ground-water withdrawals.

The modeled area extended about $5 \mathrm{mi}$ into the saline-water zone of the aquifer and allowed lateral flow in this zone. The magnitude of flow in or out of the modeled area probably is negligible for model-analysis purposes.

\section{Inflow and Outfiow at Aqulfer Boundaries}

Not all inflow and outflow to and from the Edwards aquifer can be determined from available data. However, the long-term balance between measured inflow and outflow and stability of water levels indicates that unmeasured flows are small or approximately balanced. Limited water-level observations in the saline-water zone in Bexar and Uvalde Counties indicate that water levels are lower in the saline-water zone than nearby water levels in the freshwater zone. The hydraulic gradient thus prevailing toward the saline-water zone indicates some flow into the salinewater zone. Most of the flow from the freshwater zone of the aquifer to the saline-water zone is in southeastern Uvalde and southwestern Medina Counties (fig. 16). However, the amount crossing the limits of the modeled area ( $5 \mathrm{mi}$ into the saline-water zone) probably is small. A small quantity of outflow, when water levels are high-standing, might cross the ground-water divide at the northeast boundary of the study area.

Leakage between the Edwards aquifer and the shallower, water-yielding Austin Chalk takes place along faults in a few places. The leakage is indicated by water-level changes in wells of the Austin Chalk that appear to be responding to recharge or pumping in the Edwards aquifer. Most of this leakage from the Edwards aquifer is greater when heads in the aquifer are high. Near the junction of the West Nueces and Nueces Rivers in Uvalde County, discharge of water from the Edwards aquifer by leakage probably is to overlying permeable alluvial and low terrace deposits (Sayre, 1936). The quantity of leakage is unknown but probably is not sufficient to have a major effect on the interpreted regional ground-water-flow pattern in the Edwards aquifer.

Model analysis indicates at least two areas of possible ground-water inflow along the updip limit of the unconfined Edwards aquifer. One area is in northeastern Medina County (Rio Medina inflow), and the other is in Comal County along the Hueco Springs fault (Hueco Springs inflow). Inflow to the Edwards aquifer in northeastern Medina County probably originates as infiltration of streamflow into the lower Glen Rose Limestone along Cibolo Creek in northern Bexar County. The hypothesized ground-water flowpath is along cross faults toward Haby Crossing fault. Here, southwestward flow along the upthrown side of this barrier fault probably extends to a position where the Edwards aquifer and the lower Glen Rose Limestone 
Table 5. Major storage units of the Edwards aquifer in the San Antonio area, Texas ${ }^{1}$

\begin{tabular}{|c|c|}
\hline Name & Description \\
\hline Western & $\begin{array}{l}\text { Includes the unconfined aquifer west of the Woodard Cave fault and the complex of faults in the Uvalde } \\
\text { area that is an extension of the Medina Lake fault. Eastern limit is the topographic divide between } \\
\text { Sabinal River and Seco Creek. Most of the recharge comes from losses of flow in the Nueces, West } \\
\text { Nueces, Frio, Dry Frio, and Sabinal Rivers. Has the largest storage capacity of the four units. Is the } \\
\text { most remote from the major discharge points. Yields water to the confined zone rather sluggishly. }\end{array}$ \\
\hline $\begin{array}{l}\text { Western } \\
\text { Medina }\end{array}$ & $\begin{array}{l}\text { Includes the unconfined aquifer between the western storage unit and the Medina Lake fault. Most of the } \\
\text { recharge comes from Hondo and Seco Creeks and from Medina Lake. }\end{array}$ \\
\hline $\begin{array}{l}\text { Eastern } \\
\text { Medina }\end{array}$ & $\begin{array}{l}\text { Includes the unconfined aquifer between the western Medina storage unit and generally along the Haby } \\
\text { Crossing fault. Receives most of its recharge from Medina River, Medina Lake, and several small } \\
\text { creeks. }\end{array}$ \\
\hline Eastern & $\begin{array}{l}\text { Includes the unconfined aquifer east of the eastern Medina storage unit. The storage in this unit is } \\
\text { strongly influenced by the Northern Bexar fault and the Hueco Springs fault. The recharge is primarily } \\
\text { from several small streams, especially Cibolo Creek. }\end{array}$ \\
\hline
\end{tabular}

${ }^{1}$ Modified from Maclay and Land (1988).

Table 6. Major flow units of the Edwards aquifer in the San Antonio area, Texas ${ }^{1}$

\begin{tabular}{cc}
\hline Name & Description \\
\hline $\begin{array}{c}\text { Western- } \\
\text { southern }\end{array}$ & $\begin{array}{c}\text { Source of water is the western storage unit. Geometry of the aquifer causes the water to take the } \\
\text { southernmost route from the area of recharge to points of discharge that extend to Comal Springs. Large } \\
\text { portion of water moves through the western part of an opening (Knippa gap) in the Medina Lake fault- } \\
\text { Uvalde horst complex near Sabinal and in a graben in the Uvalde area. Most or all of this flow is } \\
\text { withdrawn by irrigation wells in Medina County and for the city of San Antonio water supply. }\end{array}$ \\
$\begin{array}{c}\text { South- } \\
\text { central }\end{array}$ & $\begin{array}{l}\text { Source of water is the western Medina storage unit. The Medina Lake fault functions as a major barrier of } \\
\text { ground-water flow and diverts the water to the southwest, where it moves through the eastern part of the }\end{array}$ \\
Knippa gap near Sabinal that is described above. After the water moves past the opening, it turns sharply \\
to the east. The major discharge points are irrigation wells in Medina County, public-supply wells in San \\
Antonio, and Comal Springs. \\
North- \\
central
\end{tabular}$\quad \begin{aligned} & \text { Source of water is the eastern Medina storage unit. Much of the flow is diverted to the southwest by the } \\
& \text { Haby Crossing fault before it turns to the east. Major discharge points are public-supply wells in San } \\
& \text { Antonio and Comal and San Marcos Springs. Flow merges with the two southern flow units at Comal } \\
& \text { Springs. }\end{aligned}$

${ }^{1}$ Modified from Maclay and Land (1988). 
are juxtaposed across the fault. At this location, water in the lower Glen Rose Limestone probably discharges into the Edwards aquifer. Further evidence of inflow is provided by the greater-than-normal sulfate concentration in water from the Edwards aquifer in this areasimilar to water with large sulfate concentrations in the lower Glen Rose Limestone.

In Comal County, cross-formational inflow from a highly permeable dolomitic unit of the upper part of the Glen Rose Limestone (Abbott, 1973) to the unconfined Edwards aquifer might occur along the Hueco Springs fault. The dolomitic unit has cavernous porosity, and large caves exist in this unit. Precipitation north and west of Hueco Springs fault infiltrates through the Edwards to enter the dolomitic unit. Ground water flows southward to southeastward along cross faults toward the major northeast-trending faults that interrupt the generally southeastward flow. Eventually the flow enters the complex structural graben adjacent to the Hueco Springs fault. The flow in the graben is northeastward toward Hueco Springs.

\section{Recharge}

Recharge to the Edwards aquifer occurs primarily in the outcrop area of the Edwards Plateau. The recharge area contains many steeply inclined, normal faults that extend across the stream channels. Many of these faults provide a pathway for water to move from the stream channel to the water table of the unconfined Edwards aquifer. Here, the water table lies at depths generally greater than $100 \mathrm{ft}$ below the stream channels. All of the base flow and some of the storm runoff of streams crossing the recharge area infiltrate to the unconfined aquifer. Recharge from this stream infiltration averaged 635,500 acre-ft/yr during 1934-88. In the Nueces River Basin (including the West Nueces, Nueces, Dry Frio, Frio, and Sabinal Rivers, and Seco and Hondo Creeks) the U.S. Army Corps of Engineers (1965) estimated that infiltration capacity along the streams varies from 500 to greater than $1,000 \mathrm{ft}^{3} / \mathrm{s}$.

Recharge to the Edwards aquifer is dominated by streamflow losses. All major streams that cross the recharge area, except for the Guadalupe River, lose water to the Edwards aquifer. Major streams that cross the recharge area are the West Nueces, Nueces, Dry Frio, Frio, Sabinal, Medina, Guadalupe, and Blanco Rivers, and Seco, Hondo, Verde, Salado, Cibolo, Dry Comal, and Purgatory Creeks (pl. 11). The Guadalupe River gains rather than loses water because the river stage is normally slightly lower than the head in the aquifer in the reach where the aquifer is exposed in the streambed.

Recharge from direct infiltration of precipitation is relatively small. This is mainly because the available volumes of water from direct precipitation are small when compared to the enormous volumes of water that can accumulate in the channelized flow of streams.

\section{Method of Determining Recharge}

Recharge to the Edwards aquifer in the Balcones fault zone is determined from records of streamflowgaging stations upstream and downstream from the recharge area and estimated runoff in the recharge area (pl. 11). Essentially, recharge in the drainage area of a losing stream is calculated by adding the flow at the upstream gaging station and the estimated flow in the interstream area of the recharge area, and subtracting the flow at the downstream gaging station. Puente (1978) documented the details for calculating the annual recharge to the Edwards aquifer. The streamflow-gaging stations used to calculate recharge are either a short distance upstream of the northern edge or downstream of the southern edge of the recharge area of the aquifer. Puente (1978) concluded that evapotranspiration losses are negligible because of the rapid infiltration to the water table in the recharge area.

Streamflow data are available for most of the basins in the recharge area; however, approximately 30 percent of the total recharge area is ungaged because suitable sites for gages are not available. The estimated rate of recharge in the ungaged areas is based on the assumption that the runoff characteristics are similar to those of adjacent gaged areas. The procedures are explained in the detailed analyses of the individual basins (Puente, 1978).

\section{Unmeasured Inflow}

Unmeasured inflow to the Edwards aquifer might occur as flow from adjacent aquifers that are hydraulically connected with the Edwards aquifer. Faulting provides the hydraulic connection (1) along major faults where the Edwards aquifer is juxtaposed against other permeable strata and (2) along fault planes that are highly permeable because of fracturing and subsequent dissolution of carbonate rocks and where the fault plane itself provides hydraulic connection between vertically separated aquifers of different hydraulic head. Examples of inflow along faults are 
described in the previous section "Inflow and Outflow at Aquifer Boundaries."

Unmeasured flow from the Edwards aquifer on the Edwards Plateau to the Edwards aquifer in the Balcones fault zone occurs where geologic and hydraulic continuity exist between the two parts of the Edwards aquifer in the drainage basin of the Nueces River. However, local flow patterns in the Edwards Plateau indicate that most ground water probably moves toward springs discharging along the plateau escarpment and that direct underflow from the Edwards Plateau to the Edwards aquifer in the Balcones fault zone probably is not substantial.

Under modern hydrologic conditions, leakage to the Edwards aquifer through any interconnected openings of the rock matrix of the overlying and underlying confining units is believed to be a negligible component of the water budget of the Edwards aquifer. The confining units are thick and consist of poorly permeable clay, shale, and marl.

\section{Distribution of Recharge}

The locations of recharge basins for the Edwards aquifer are shown in plate 11. Graphs showing the calculated annual recharge for these basins for 1934-88 are shown in figure 17. For a comparison between annual recharge and the average annual recharge for 1934-88, see figure 18.

Normally, most recharge occurs in the basins west of Bexar County. The streams west of the Medina River (Nueces River Basin) lose 64 percent of their flow in the recharge area to the Edwards aquifer, on the basis of the 1934-88 data. Much of the annual flow of the Medina River, largest tributary to the San Antonio River, is impounded in Medina Lake (U.S. Army Corps of Engineers, 1965). Of the volume impounded, approximately one-half seeps into the Edwards aquifer from the lake and its irrigation facilities (U.S. Army Corps of Engineers, 1965).

In the Guadalupe River Basin, Dry Comal Creek is a major contributor of recharge to the Edwards aquifer. The creek loses 71 percent of its annual flow to the aquifer. The Guadalupe River, as previously mentioned, contributes no recharge to the aquifer.

Field studies of streamflow along channels in the recharge area were made during 1980 and 1981 to determine distribution of streamflow losses and gains (Land and others, 1983). The streams investigated included the West Nueces, Nueces, Dry Frio, Frio, and
Sabinal Rivers, and Seco, Hondo, and Verde Creeksall in the upstream drainage area of the Nueces River. Streamflow measurements made during the recessions of stormflows identified areas of direct recharge to the Edwards aquifer or to aquifers hydraulically connected with the Edwards.

Sayre (1936, p. 74) reported that the Nueces River lost large quantities of water where it flows over the Edwards aquifer outcrop. At most stages, the river also lost considerable water in the 7-mi reach between the mouth of the West Nueces River and U.S. Highway 90. Along this reach, the bedrock consists of the Austin Group and Buda Limestone and is highly faulted. Downstream from this reach, there is a considerable increase in streamflow caused by inflow from springs. Land and others (1983) described a seepage study that identified a similar pattern of water losses and gains.

Studies of methods for augmenting recharge to the Edwards aquifer were made in the 1960's by the U.S. Army Corps of Engineers (1965). The studies concluded that because the base flow of most streams in the Edwards Plateau that cross the recharge area is lost to the Edwards aquifer, additional water for recharge must come from floodflows, which occur at rates that exceed the infiltration capacity of the rocks. The U.S. Army Corps of Engineers proposed building dams in the Edwards Plateau to retain floodflows, whereby later releases of that water would be at a rate equal to or less than the infiltration capacity of the rocks. Large dams on the Nueces, Frio, Sabinal, and Blanco Rivers were proposed as recharge structures. In addition, many smaller floodwater-retarding structures to be constructed by the U.S. Soil Conservation Service have been considered by water planners, and some have been constructed.

\section{Discharge}

Freshwater is discharged from the Edwards aquifer primarily from wells, springs, and seeps. A much smaller quantity of fresh ground water is discharged to the saline-water zone of the aquifer. Annual discharge generally has increased since the middle to late 1960's, and beginning in 1968, annual discharge consistently has exceeded the average annual recharge of 635,500 acre-ft (fig. 18). This increase largely reflects a doubling of the well pumpage. However, springflow also has increased and has exceeded the average annual springflow $(359,500$ acre- $f t)$ in most years since the late 1960's. Greater-than-average recharge during most 

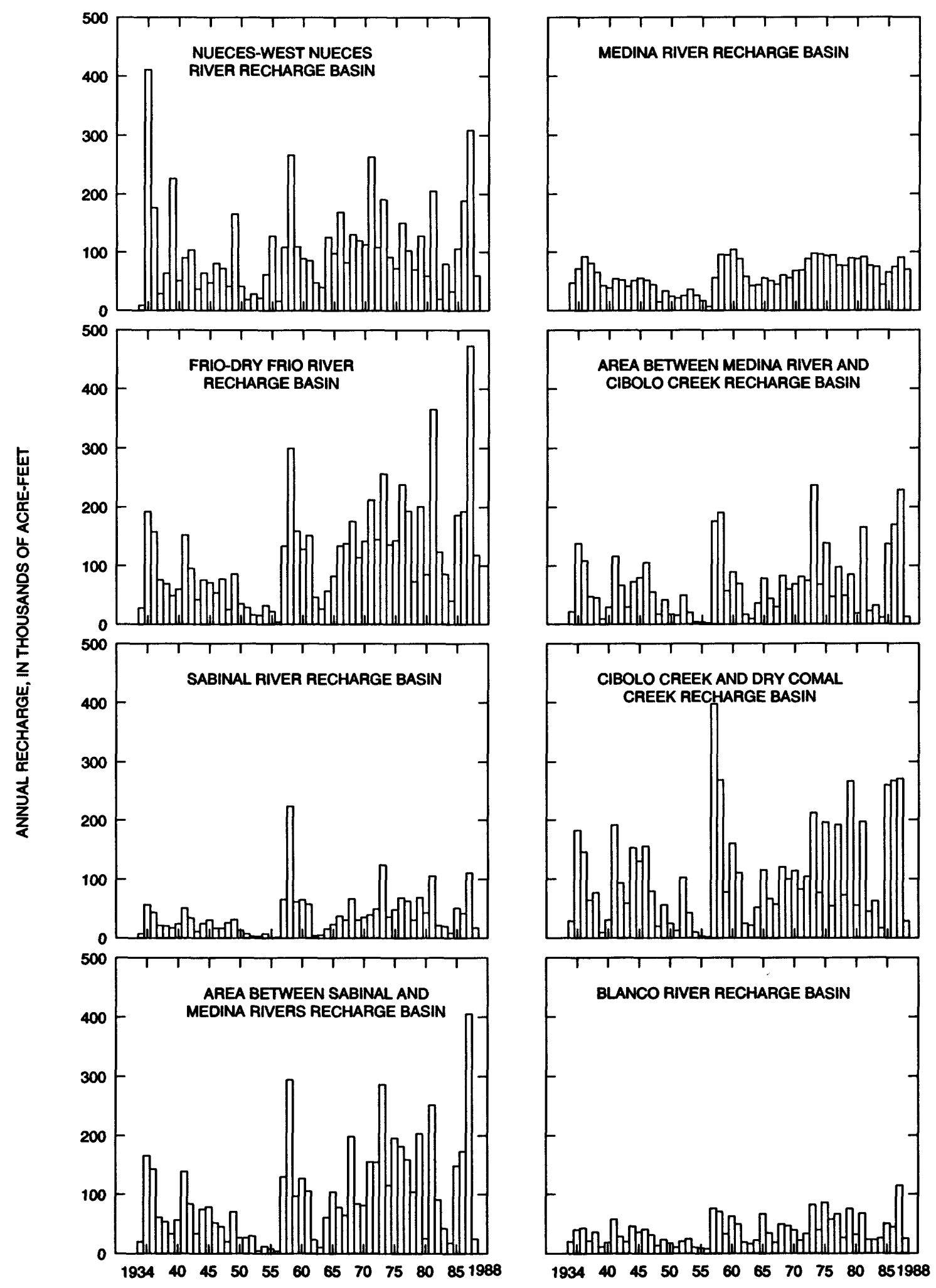

YEAR

Figure 17. Annual recharge for recharge basins of the Edwards aquifer in the San Antonio area, Texas, 1934-88. 


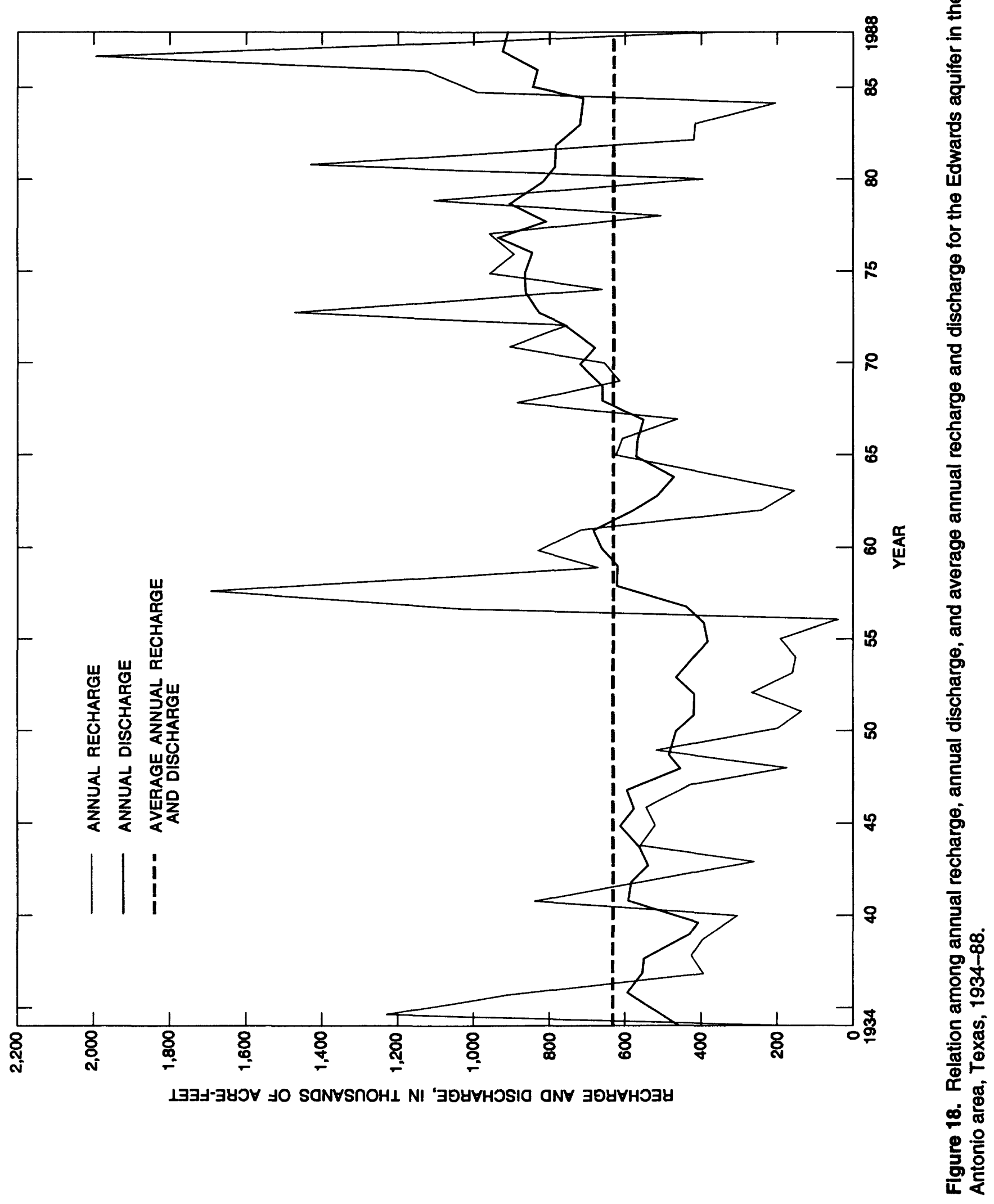


years since the late 1960's (fig. 17) has caused the increased spring discharge from the Edwards aquifer.

\section{Withdrawals from Wells}

Thousands of water wells tap the Edwards aquifer. The greatest density of wells is in Uvalde and Bexar Counties. The annual number of new wells constructed is increasing because additional land is being irrigated in Uvalde, Medina, and Bexar Counties, and the population is growing. The location of pumping centers for the Edwards aquifer and ground-water withdrawal rates for 1972 are shown in plate 12. Pumpage is concentrated in the confined part of the Edwards aquifer, with the largest withdrawals in and around San Antonio and near Uvalde and close to the downdip limit of the freshwater zone.

Many of the wells in the freshwater zone of the confined aquifer can yield more than $1,000 \mathrm{gal} / \mathrm{min}$. Yields of wells generally are limited more by the capacity of the pumps to discharge water than by the ability of the aquifer to provide water to the well. The density of wells in the unconfined aquifer is substantially less than that in the confined aquifer, and typically the yields are smaller because the saturated thickness and transmissivity generally are much less. Wells developed in the saline-water zone of the Edwards aquifer usually flow at the land surface at rates ranging from less than 100 to several hundred gallons per minute.

Records of annual pumpage by wells used for public supply, irrigation, and industrial use are available in the files of the USGS office in San Antonio. Pumpage for public supply generally is metered, and records are kept by the municipalities. The pumpage of most irrigation wells is estimated on the basis of power consumption. Records of pumpage by military and industrial facilities are obtained from the files of those organizations.

Most water wells tapping the Edwards aquifer are drilled, using the rotary method, to the base of the Del Rio Clay or top of the Edwards aquifer. After installing casing to the top of the aquifer, an open hole is drilled into the aquifer to a depth where a cavernous zone of large permeability is penetrated. In many wells, several cavernous zones are penetrated; however, most wells do not penetrate the entire thickness of the Edwards aquifer. The depth of wells penetrating the Edwards aquifer ranges widely depending on the depth to the top of the aquifer. Well depths range from less than $500 \mathrm{ft}$ in the unconfined area to more than $3,000 \mathrm{ft}$ in some wells tapping the confined aquifer in southeastern Uvalde County.

Public-supply and irrigation wells often have large (10 to $30 \mathrm{in}$.) diameters and penetrate a substantial part of the total thickness of the aquifer. Many of these wells have been treated with acid and subsequently pumped at a high rate to develop the maximum capacity, which ranges from several hundred to more than $10,000 \mathrm{gal} / \mathrm{min}$. At many wells, a larger specific capacity (yield per unit of drawdown) could be obtained by drilling the well deeper in order to tap additional permeable zones in the aquifer. The larger specific capacities are in northeastern Bexar County where several wells are reported to have specific capacities in excess of $6,000(\mathrm{gal} / \mathrm{min}) / \mathrm{ft}$ of drawdown.

\section{Springs and Seeps}

Springs and seeps are the major natural discharge outlets for the Edwards aquifer, and they account for nearly all natural discharge from the aquifer. The locations of major artesian springs in the Edwards aquifer (pl. 1) are structurally controlled. Structure controls the ground-water flowpaths by diverting flow along barrier faults and providing vertical openings at a few places along faults where springs can emerge. Artesian springs are present where water in the confined Edwards aquifer is under sufficient pressure to rise to the surface through a natural break in the overlying confining beds. The springs emerge from faults that intersect the aquifer at depth and provide a passageway for water to rise to the land surface at locations near structural constrictions. For example, the structural graben through which most of the flow to Comal Springs in Comal County occurs, pinches out and thereby causes ground water to rise along the Comal Springs fault near the constriction. San Antonio and San Pedro Springs in Bexar County discharge ground water that rises along a major fault near a structural horst in a complex graben. The horst blocks groundwater flow in the graben and diverts flow around its northern and southern margins.

Leona Springs consist of a number of seeps along the channel of the Leona River in Uvalde County. These seeps emerge from permeable gravel within the channel. The gravel directly overlies the Edwards aquifer at some places, and at other places the gravel is hydraulically connected, by faults, to the confined Edwards aquifer. Water rising from the Edwards 
aquifer discharges into the permeable gravel, and part of the discharges forms seeps. The altitude of the highest point of discharge from the Edwards aquifer to the gravel varies with the potentiometric surface of the Edwards aquifer in the vicinity of springs. A substantial volume of discharge from the Edwards aquifer moves through the permeable gravel in the Leona River valley and discharges at other seeps in the gravel at lower altitudes.

Leona Springs emerged because of a structural restriction in Uvalde County east of Uvalde and north of a structural horst in the Edwards aquifer. Because of this restriction, the aquifer cannot transmit all of the flow from the west as subsurface flow to the east. During periods of large recharge, water levels in the Edwards aquifer west of the restriction rise rapidly to land surface. Consequently, springs in the Leona River valley have substantial discharge for much of these periods.

Historical hydrographs of spring discharge for Hueco, Comal, and San Marcos Springs are shown in figure 19. The discharge at Comal Springs has been substantially reduced at times by increases in pumpage in Bexar County. The only period of zero flow at Comal Springs was June 13, 1956, to November 4, 1956, near the end of a severe drought. During the most intense part of the drought, limited recharge and increased pumpage lowered water levels below the outlet of the spring.

Hydrographs of Hueco and San Marcos Springs generally show the same long-term trend observed at Comal Springs, but sometimes the flow at Hueco Springs fluctuates more than at Comal Springs. Waterlevel fluctuations in wells just north of the Hueco Springs fault correlate best with the fluctuations in the discharge of Hueco Springs. The smaller average discharge and abrupt changes in flow of the springs indicate that the recharge area for the springs is relatively small. Water-chemistry data, water-temperature data, and samples for tritium analyses collected by the USGS also indicate a local source of water for Hueco Springs.

San Marcos Springs discharges at an altitude of $574 \mathrm{ft}$ above sea level (altitude of the pool level at San Marcos Springs), or about $49 \mathrm{ft}$ lower than the altitude of Comal Springs. The similarity in the fluctuations of the discharge of San Marcos and Hueco Springs indicates that a substantial part of the springflow is derived from water that enters the aquifer in Comal and Hays Counties north of the Hueco Springs fault. During the drought of the 1950 's, the monthly average springflow at San Marcos Springs was sustained at about $60 \mathrm{ft}^{3} / \mathrm{s}$ by subsurface flow from the confined part of the aquifer to the west (Puente, 1976).

San Antonio Springs has had intermittent flow since 1950 and flows only during periods when water levels in the aquifer are at a high stage. Increased pumpage from wells in San Antonio caused the interruptions of the springflow of San Antonio Springs and also has caused a cessation of flow from San Pedro Springs (Brune, 1975).

\section{Unmeasured Outflow}

Subsurface outflow from the freshwater zone to the saline-water zone of the confined Edwards aquifer probably occurs at places along the downdip limit of the freshwater zone from Bexar County westward. The potential for discharge is indicated by the lower heads in the saline-water zone immediately downdip and by the similarity of the hydrographs of water levels in the freshwater and saline-water zones, an indication of some hydraulic continuity. The discharge to the salinewater zone is greater during periods of large recharge when the hydraulic gradient increases from the freshwater zone to the saline-water zone. However, the volume of flow from the freshwater zone to the salinewater zone is very small in comparison to the flow through the confined freshwater zone toward the major springs and seeps. This results from relatively small permeabilities in the saline-water zone and from barrier faults, which restrict the free movement of water across the interface between the freshwater and saline-water zones.

\section{Ground-Water Storage and Water Levels}

\section{Ground Water in Storage}

The total volume of circulating water in the freshwater zone of the Edwards aquifer is equal to the volume of interconnected, drainable voids (which contribute to effective porosity) in the saturated thickness of the aquifer. The effective porosity of the unconfined part of the Edwards aquifer is a controlling factor in the determination of major storage changes that occur when water levels decline or rise.

The bulk volume of freshwater in storage in the Edwards aquifer can be computed from the areal extent and thickness of the aquifer and its effective porosity. The areal extent of the aquifer is about $3,180 \mathrm{mi}^{2}$, of 


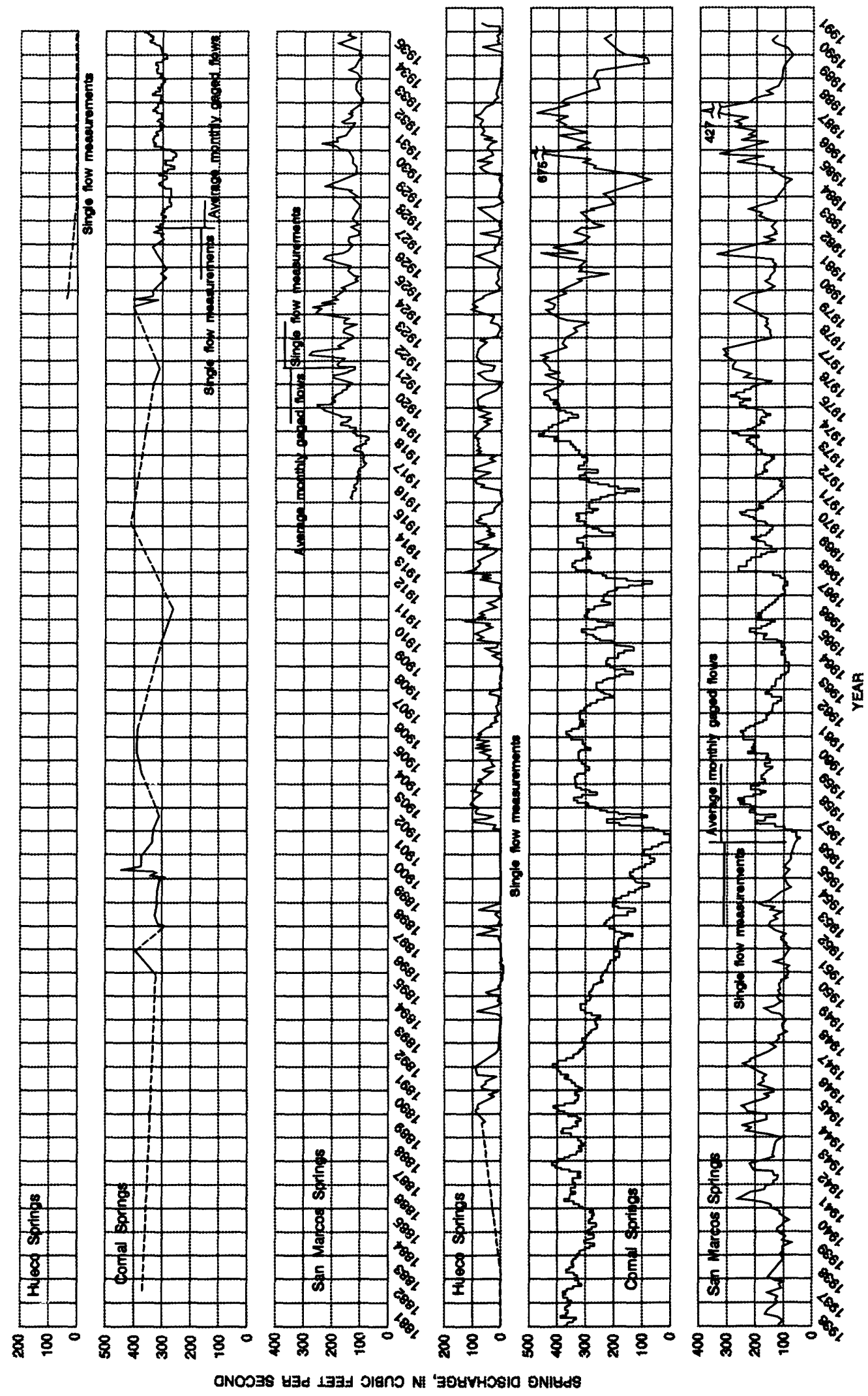

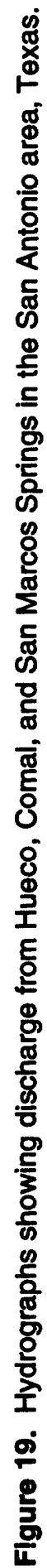


which about $1,170 \mathrm{mi}^{2}$ is unconfined. The areal extent of the unconfined and confined areas of the Edwards aquifer, by county, is as follows:

\begin{tabular}{lccc}
\hline County & $\begin{array}{c}\text { Unconfined area } \\
\left(\mathrm{ml}^{2}\right)\end{array}$ & $\begin{array}{c}\text { Confined ares } \\
\left(\mathrm{ml}^{2}\right)\end{array}$ & $\begin{array}{c}\text { Total area } \\
\left(\mathrm{ml}^{2}\right)\end{array}$ \\
\hline Bexar & 119 & 480 & 599 \\
Comal & 172 & 54 & 226 \\
Hays & 96 & 47 & 143 \\
Kinney & 118 & 115 & 233 \\
Medina & 219 & 834 & 1,053 \\
Uvalde & 448 & 478 & 926 \\
\hline TOTAL & 1,172 & 2,008 & 3,180 \\
\hline
\end{tabular}

The average saturated thickness is about $500 \mathrm{ft}$ for the confined part and $150 \mathrm{ft}$ for the unconfined part. The effective porosity generally ranges from 2 to 14 percent (Maclay and Small, 1976); 6 percent is considered to be average. Using these numbers, the total volume of circulating freshwater in the Edwards aquifer is about 45 million acre-ft-38 million acre- $\mathrm{ft}$ in the confined part and 7 million acre- $f t$ in the unconfined part. However, much of this water is at depths exceeding current economic limitations. When water levels in the aquifer decline, the loss in storage is in the unconfined part of the aquifer because of the difference in storage coefficients for the two parts.

If increased pumpage from the Edwards aquifer continues, coupled with annual recharge approximating the average annual recharge (1934-88), withdrawals will decrease springflow or reduce the volume of water in storage, or both. Continued lowering of the potentiometric surface could cause dewatering in the unconfined part of the aquifer. Lowering the potentiometric surface in the confined part of the aquifer might not cause dewatering, but could result in release of water from storage by a volume equivalent to the compressibility of the aquifer and of its contained water. This volume is 2 to 3 orders of magnitude less than the volume that would be released from storage with a similar decline of water levels in the unconfined area.

Stresses on the Edwards aquifer affect storage, ranging from minimal fluctuations in storage caused by barometric changes to substantial reductions in storage resulting from long-term drought. The duration of pumpage stresses ranges from less than 1 day to 1 year or more. Short-term stresses, within 24 hours, cause local changes in water levels that affect pumping lifts of nearby wells. Long-term stresses cause water-level changes throughout the aquifer that affect springflow and pumping levels. All of the stresses affect storage in the aquifer by widely differing quantities. The most substantial stresses to the water levels and to storage in the Edwards aquifer are those long-term stresses related to pumpage rates, coupled with seasonal, annual, and climatic variation in recharge. The resulting changes in storage in the aquifer affect the regional potentiometric surface, which, in turn, affects local flow patterns.

The volume of water stored in the zone of watertable fluctuations in the unconfined aquifer-an increment of total storage in the aquifer-can be estimated using estimates of recharge and records of discharge and water levels in wells, or a record of the natural recession of springflow during an extended period of no recharge. In the unconfined aquifer, a change in water levels reflects the draining or filling of the interconnected pore space. Estimates of water volumes stored in the Edwards aquifer were made using data for each of three drought periods (1937-39, 1950-56, and 1961-67). The difference between the accumulated recharge and accumulated discharge for each drought period was referenced with respect to the annual change in water level at an observation well (AY-6837-203) immediately north of downtown San Antonio. The estimates of change in aquifer storage per foot to the annual change in water levels at the observation well are as follows: 20,000 acre- $\mathrm{ft} / \mathrm{ft}$ for the drought of $1937-39 ; 37,000$ acre- $\mathrm{ft} / \mathrm{ft}$ for the drought of 1950-56; and 31,000 acre-ft/ft for the drought of 1961-67. The relation between ground-water levels at the observation well and storage in the Edwards aquifer is shown in figure 20 . The difference between record high and low water levels represents about 3,400,000 acre-ft of water in storage just within the zone of the record high water level in October 1973 and the record low water level in August 1956.

The volume of water stored in the aquifer above the altitude of a spring outlet can be estimated from the declining slope of the springflow hydrograph during a period of no substantial recharge to the aquifer. This method assumes that all discharge is by springflow. Following the method and formula described by Mijatovic (1968) the estimated volumes of water stored in the Edwards aquifer above the altitude of the spring 

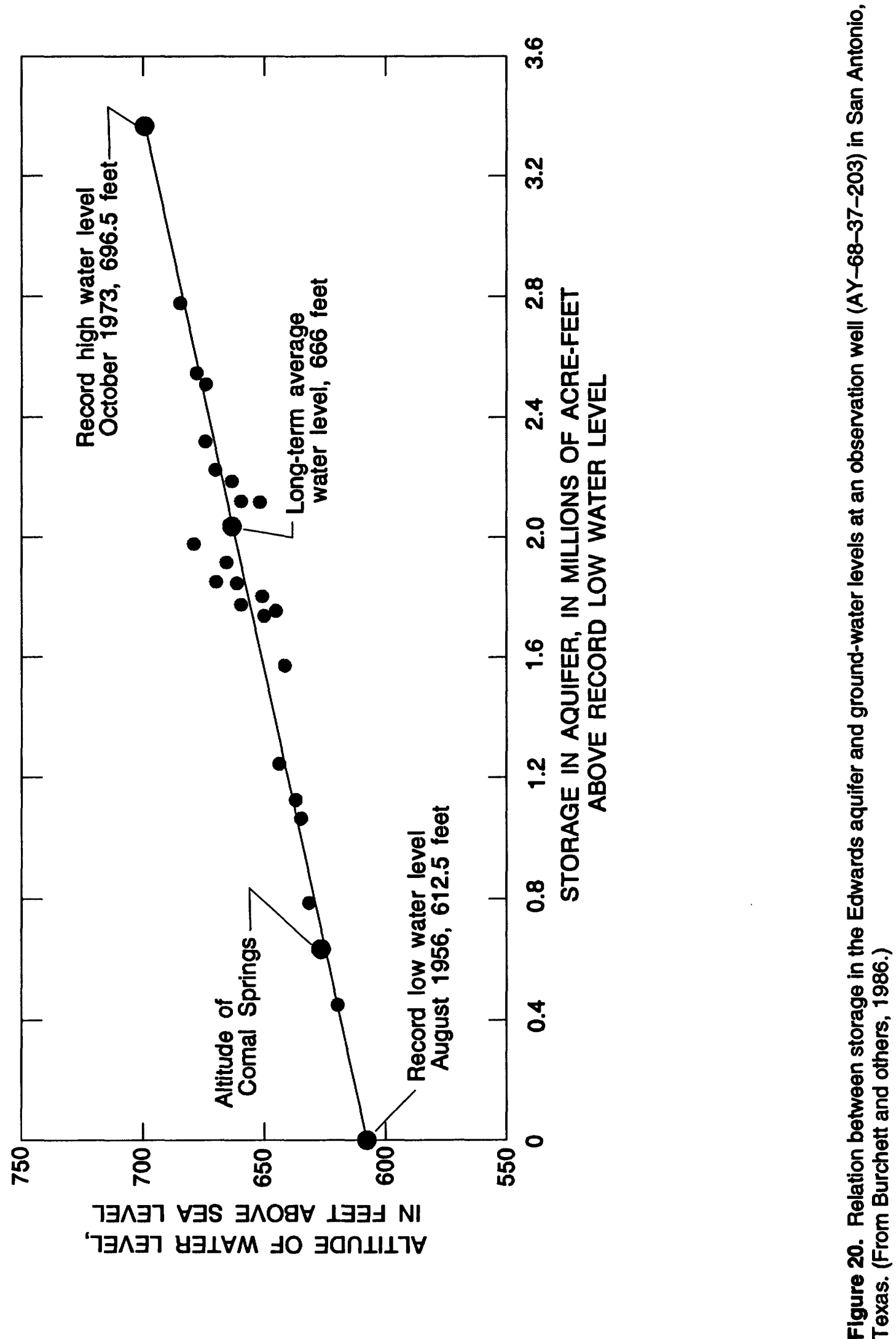
outlet (that exists at mean discharge for that spring) are as follows:

\begin{tabular}{lcc}
\hline Spring & $\begin{array}{c}\text { Mean discharge } \\
\left(\mathrm{ft}^{3} / \mathrm{s}\right)\end{array}$ & $\begin{array}{c}\text { Volumes in storage } \\
(\mathrm{acre}-\mathrm{ft})\end{array}$ \\
\hline Hueco & 36.6 & 7,120 \\
Comal & 281 & $1,120,000$ \\
San Marcos & 161 & 152,000 \\
\hline
\end{tabular}

These estimated volumes of water are only increments of the total volume stored in the aquifer. Nevertheless, they could be considered as critical volumes that, if exceeded, might cause the flow of the springs to cease.

Estimates of volumes of water stored above the outlets of Comal and San Marcos Springs probably are conservative. When comparing the volume of storage above the Comal Springs outlet (at mean discharge) with the total volume of freshwater in the Edwards aquifer (45 million acre- $\mathrm{ft}$ ), it is apparent that only a small part of the aquifer has been subjected to draining and filling because of changes in ground-water levels. If the storage above the outlet at Comal Springs is equal to the estimated 1.12 million acre-ft, and the volume of water released from storage is equivalent to 30,000 acre- $\mathrm{ft} / \mathrm{ft}$ at the observation well, then a long-term drop in water level of about $37 \mathrm{ft}$ at the well during a period of no recharge and no pumpage would be representative of storage depletion that supplied the springflow to Comal Springs.

\section{Fluctuations of Ground-Water Levels}

Long-term hydrographs of water levels in selected wells tapping the Edwards aquifer show water-level trends for 1934-88 that are largely a product of the climate (fig. 21). The drought of the early 1950 's is documented by the declining trends of water levels at these wells. Major storms in the late 1950's caused a rapid rise of water levels to altitudes that were approximately equal to those before the drought. The trend in recent years continues to follow a synchronous pattern caused by differences in annual rates of recharge and discharge. However, greater amplitudes of water-level fluctuations in some wells during the 1970's and 1980's are the result of fluctuations of increased pumpage in Bexar County.

A continuous record of daily water levels in the Edwards aquifer at San Antonio has been maintained since 1911 by the city of San Antonio or by State and Federal agencies. A composite hydrograph based on water-level records of wells in the downtown area of San Antonio-the Brackenridge Park well, the Beverly Lodges well no. 26, and the Dodd Field well (J-17 or AY-68-37-203)-is shown in figure 22. Generally, water levels in the downtown area reflect variations in annual recharge and discharge. In the 1970's and 1980's, water levels have risen to record highs because of greater-than-average recharge, but the increased magnitude of the water-level fluctuations within a given year are mainly because of the magnitude of pumpage in San Antonio.

The San Antonio composite hydrograph indicates periods of rapid rises in water levels in 1913, $1919,1930,1940,1957$, and 1967 . These rises in water levels are related to recharge resulting from precipitation in the catchment and recharge areas. The longest period of declining water levels was from 1947 to 1956. The major storms of 1957 and 1958 caused dramatic rises in water levels to a position about the same as the high levels prior to the middle 1940's. The highest water levels were in the 1970's and 1980's. The lowest water levels were in 1956 , when water levels were below an altitude of $620 \mathrm{ft}$ for 4 months.

The San Antonio hydrograph indicates no net decline in water levels for the 76-year period from 1911 to 1987 . Assuming this observation well represents the entire aquifer, it can be concluded that there was no net loss of water in storage in the freshwater zone of the Edwards aquifer during that long-term period. However, records show that annual recharge generally has been greater after 1957 than before 1957. If annual recharge had been equal to or less than that prior to 1957 , the conclusion might be different.

Generally, the amplitude of seasonal and shortterm water-level changes are greater in the recharge area than in the confined area. This is the result of the proximity of the recharge, the local barrier faults that affect ground-water circulation, and the smaller transmissivity of the aquifer in the recharge area. Also, the amplitude of water-level changes is less near the springs in Uvalde, Comal, and Hays Counties.

Short-term fluctuations of water levels in the Edwards aquifer can be caused by changes in atmospheric pressure, earth tides, and earthquakes. Waterlevel fluctuations resulting from changes in barometric pressure were determined at three wells in the freshwater zone of the confined aquifer (fig. 23). The barometric pressure shows a sinusoidal pattern with a 

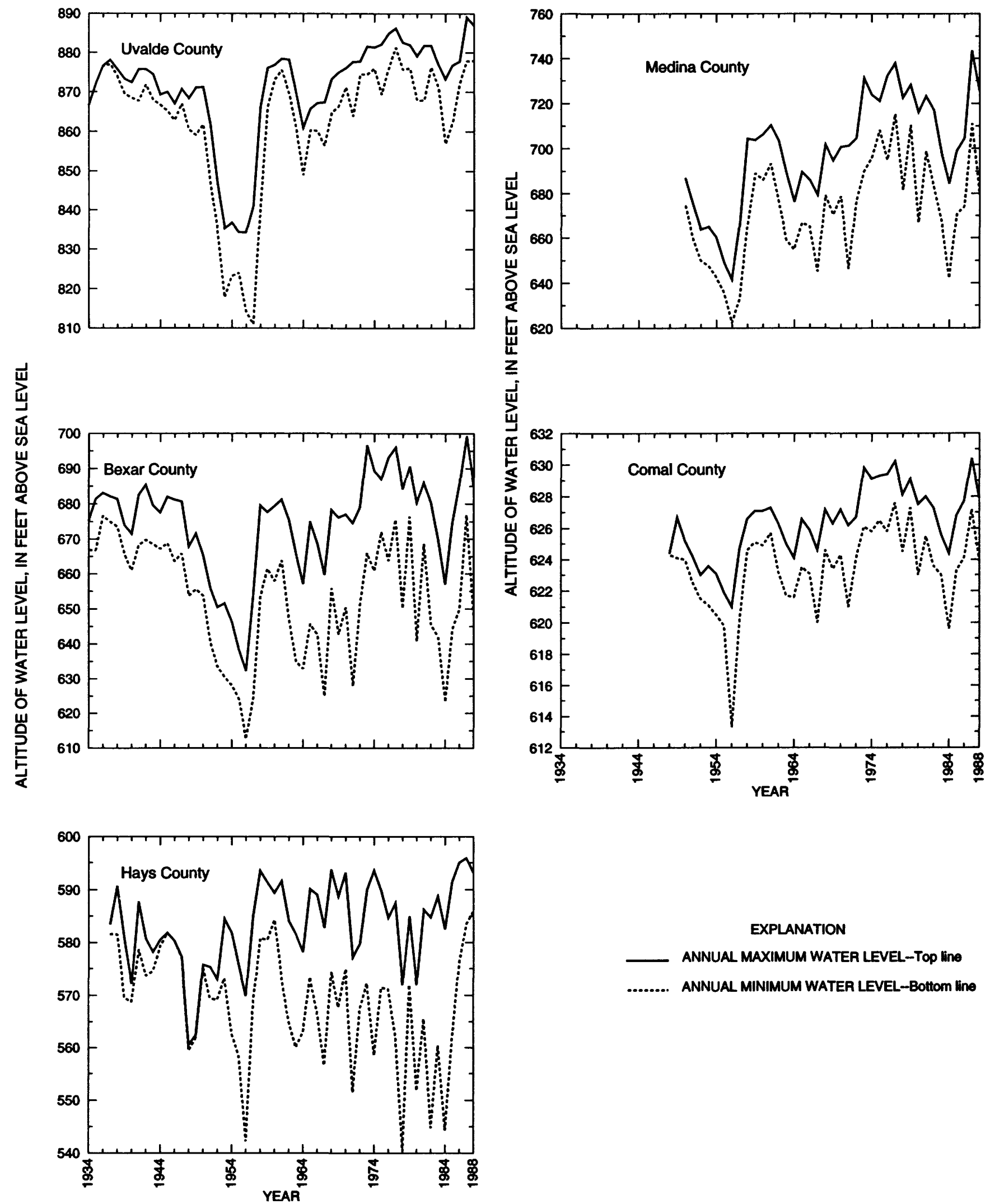

\section{EXPLANATION}

ANNUAL MAXIMUM WATER LEVEL-Top line ANNUAL MINIMUM WATER LEVEL-Bottom line

Figure 21. Hydrographs showing annual maximum and minimum water levels in selected wells in the Edwards aquifer in the San Antonio area, Texas, 1934-88. 

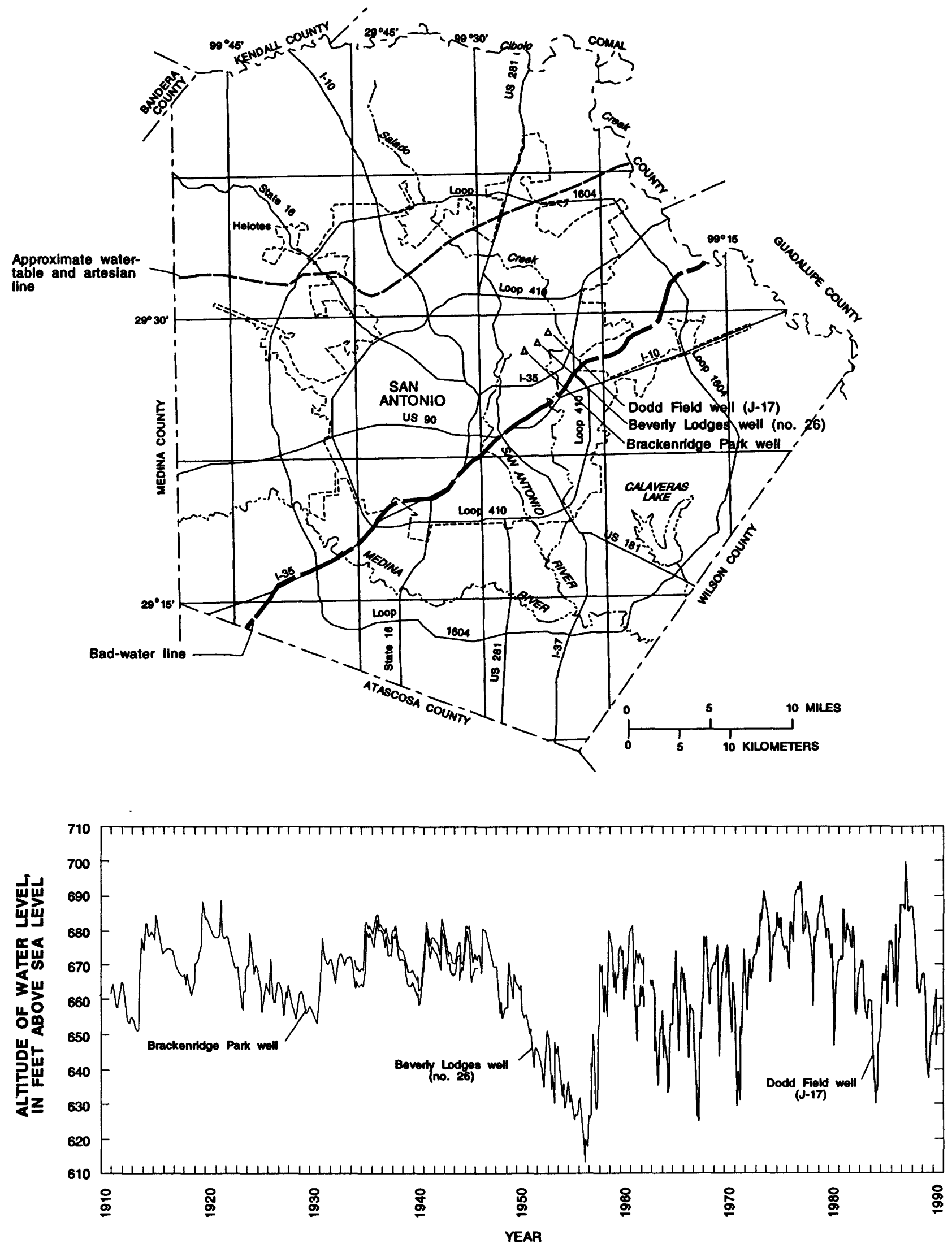

Figure 22. Composite hydrograph showing ground-water levels from several wells in San Antonio, Texas. (Modified from Maclay, Small, and Rettman, 1980.) 

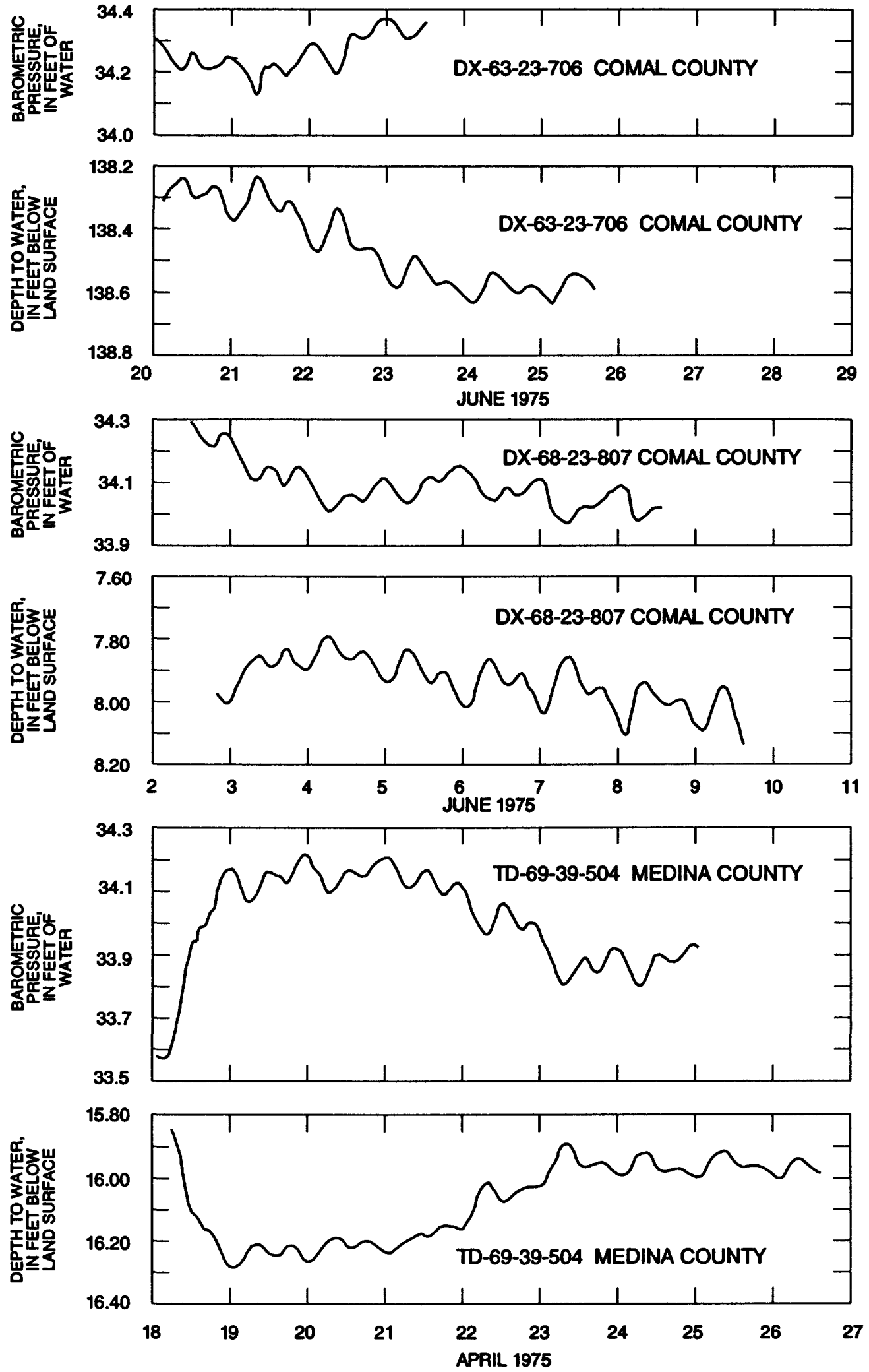

Figure 23. Relation of water-level fluctuations in wells in the San Antonio area, Texas, to barometric-pressure fluctuations. (From Maclay, Small, and Rettman, 1980.) 
period of about 12 hours. The barometric pressure, which reflects changes in atmospheric pressure, is highest around 12:00 a.m. and 12:00 p.m. and lowest around 6:00 a.m. and 6:00 p.m. Barometric efficiencies of the Edwards aquifer at the sites of the three wells ranged from 87 to 95 percent (Maclay, Small, and Rettman, 1980, p. 17). These barometric efficiencies are a measure of the relative compressibilities of the water and of the aquifer material. Water-level fluctuations from barometric pressure are small in comparison to the fluctuations caused by other factors and cause only negligible changes in storage in the aquifer.

Daily cyclic water-level fluctuations occur in the vicinity of San Antonio because of the pumping schedule of wells in the city. Hydrographs of water levels show sinusoidal fluctuations (fig. 24). In the freshwater zone of the aquifer, a daily high water level occurs about 6:00 a.m., and a daily low water level occurs about 10:00 p.m. The fluctuations of daily water levels at the Dodd Field well (J-17 or AY-68-37-203) range from about 2 to $5 \mathrm{ft}$ depending on pumpage rate. The hydrograph of water levels at the Morrill School well (AY-68-45-102) in the saline-water zone of the Edwards aquifer shows a sinusoidal pattern similar to that for the well at Dodd Field; however, the cycles at the Morrill School well lag behind the cycles of the Dodd Field well by approximately 12 hours, because of the greater distance of the saline-water well from the heavier pumpage in the freshwater zone.

\section{Ground-Water Budget}

The principal components of the ground-water budget for the Edwards aquifer are recharge in the outcrop area and discharge as springflow and pumpage. Other water-budget components, including inflow from the Glen Rose Limestone at aquifer boundaries and outflow across the downdip limit of the freshwater zone, have not been estimated but are considered relatively minor.

During 55 years (1934-88) of pertinent hydrologic data, the principal components of recharge, springflow, and pumpage have varied greatly. Recharge varied from about 44,000 to 2,000,000 acre-ft annually, and springflow varied from about 70,000 to about 580,000 acre- $f t$ annually. Annual pumpage increased from about 100,000 acre- $f$ in the 1930's to more than 500,000 acre-ft periodically in the 1980's. An "average" ground-water budget that represents long-term hydrologic conditions in the Edwards aquifer is not possible. However, the range of budget components during a 10-year period (1979-88) is shown in figure 25.

During most years, recharge does not equal discharge (fig. 18), and steady-state conditions rarely exist in the Edwards. The contrast between the water budget in the drought year of 1956 and the wet year of 1987 is shown in figure 25 . Note the large decrease in storage during 1956 and the large increase in storage in 1987. However, for the 55 years of hydrologic records, the average annual recharge of 635,500 acre- $\mathrm{ft}$ is about equal to the sum of the average annual springflow of 359,500 acre-ft and average annual pumpage of 273,000 acre- $\mathrm{ft}$ (Nalley, 1989). This indicates that there has been no long-term decrease in ground-water storage because of springflow and pumpage, as also indicated by the lack of long-term decline of the groundwater levels (figs. 21, 22).

\section{SUMMARY}

The San Antonio area, encompassing a large part of south-central Texas, centers on the highly productive Edwards aquifer-a sole-source water supply for the city of San Antonio and one of the most permeable and productive carbonate aquifers in the United States. Geologically, the area is underlain by sedimentary and crystalline rocks ranging in age from Precambrian to Holocene; however, only rocks of Cretaceous and Cenozoic age are exposed.

Lower and Upper Cretaceous rocks, mostly carbonates, are widely exposed in the San Antonio area. The Lower Cretaceous rocks are carbonates comprised mostly of mudstone and wackestone with associated miliolid grainstone and evaporite. These rocks are the result of many superimposed cycles of repetitive advances and recessions of the continental sea on a gradually subsiding continental shelf. Upper Cretaceous rocks above the Lower Cretaceous section consist of open-marine deposits of carbonates and shales that were deposited during the major encroachment of the continental sea into the interior of North America.

The Cenozoic rocks consist of clastic rocks which were derived from erosion of the tectonically uplifted continental interior. These deposits were laid down mostly as near-shore deposits by streams discharging to the receding continental sea and the Gulf of Mexico. The Late Cenozoic deposits are largely extensive alluvial deposits consisting of materials eroded from the Edwards Plateau. 

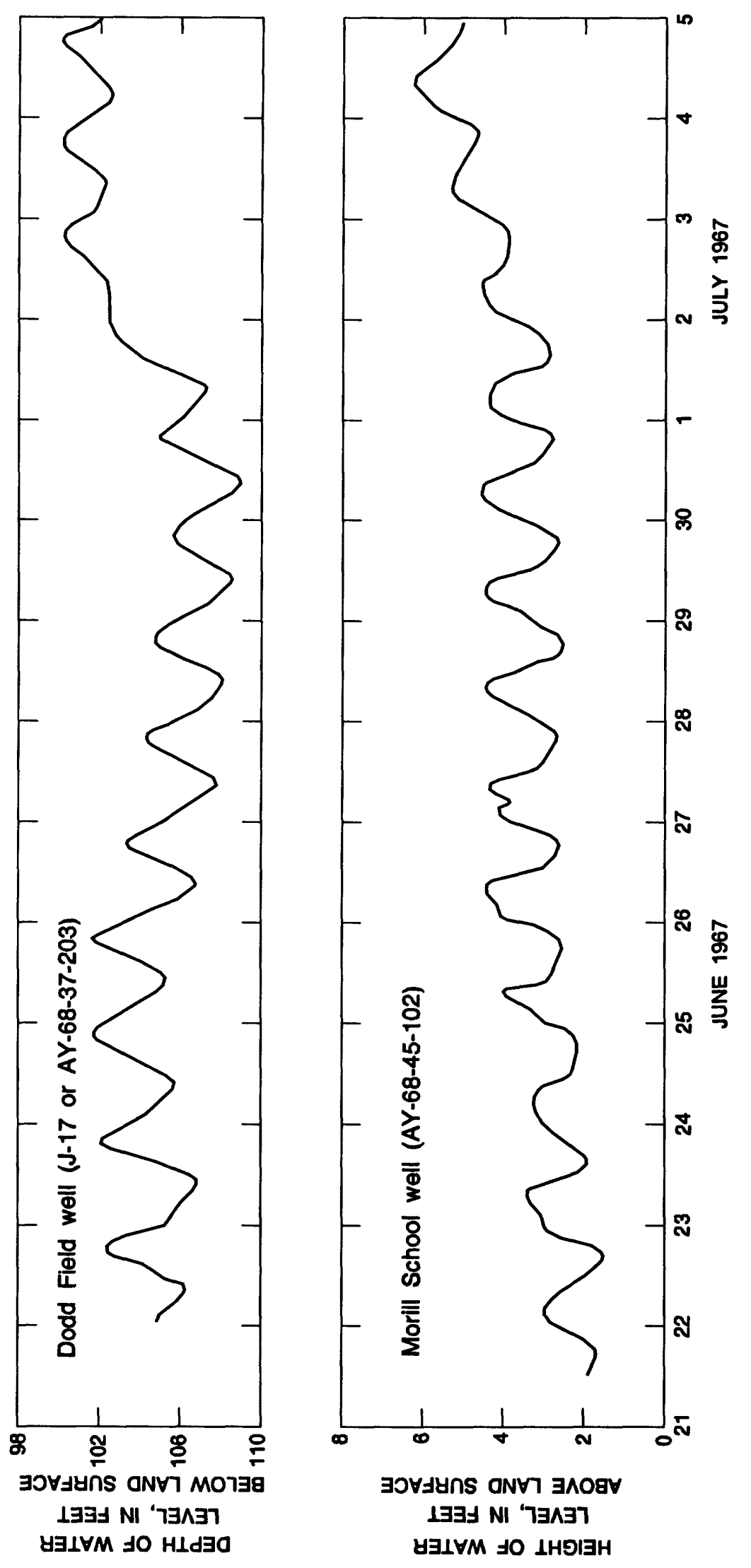

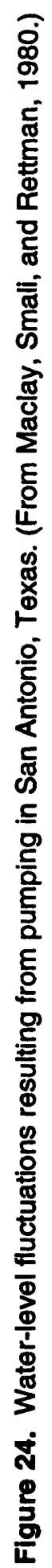


Recharge mainly from streams

on outcrop: 197,900 to $2,003,600$

acre-feet per year during $1979-88$

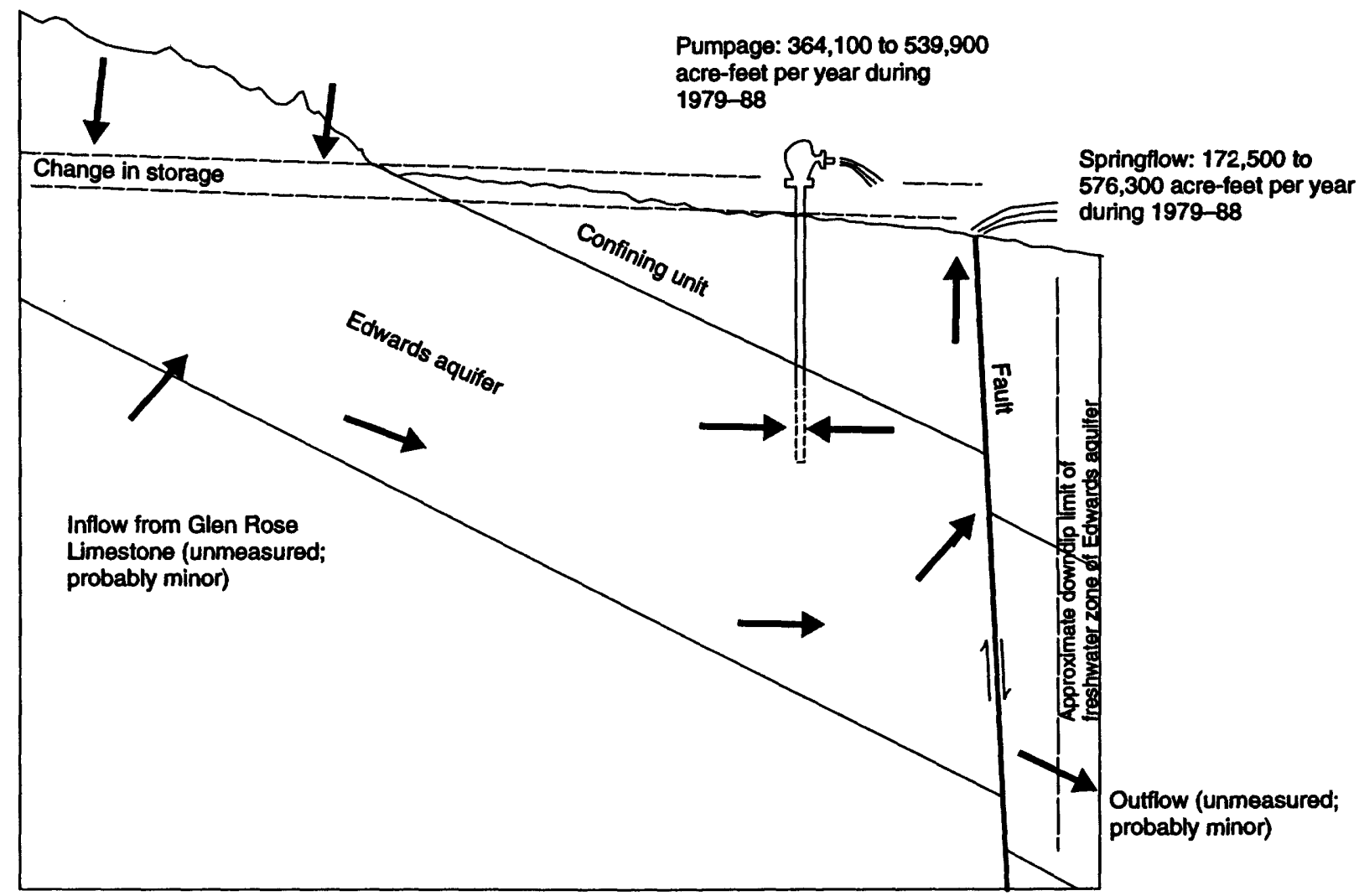

A. Variation of water-budget components during $1979-88$

\begin{tabular}{|l|r|r|}
\multicolumn{2}{c}{$\begin{array}{c}\text { Drought year } \\
(1956)\end{array}$} & $\begin{array}{r}\text { Wet year } \\
(1987)\end{array}$ \\
\hline Recharge (acre-feet) & & \\
Springflow (acre-feet) & 43,700 & $2,003,600$ \\
Pumpage (acre-feet) & 69,800 & 576,300 \\
Change in storage (acre-feet) & 321,000 & 364,100 \\
decrease (-), increase (+) & $-347,200$ & $+1,063,200$ \\
& & \\
\hline
\end{tabular}

B. Water-budget components during a drought year and a wet year

Figure 25. Generalized ground-water budget for the Edwards aquifer in the San Antonio area, Texas. 
The geologic structure of south-central Texas that affects the San Antonio area is controlled by three major elements: (1) northwest-southeast-trending lineaments that are regional in extent; (2) the Ouachita fold belt; and (3) major uplifts and arches, including the Devils River uplift, the Llano uplift, and the San Marcos arch. This structural framework can be subdivided into three areas: the Edwards Plateau, the Balcones fault zone, and the Gulf Coastal Plain. The Edwards Plateau is an uplifted area underlain by a thick crust of metamorphosed rocks of the craton. The surficial rocks of the Edwards Plateau are gently dipping strata of mostly Early Cretaceous age. The Balcones fault zone is a series of parallel northeast-trending, normal, en echelon strike faults. The Gulf Coastal Plain is a subsided area that is underlain by a continental crust of metamorphosed rocks that is thinner than the crust of the craton.

The Edwards aquifer is contained within the carbonate rocks of Early Cretaceous age. The facies in these rocks were determined largely by energy conditions within three Cretaceous depositional provinces:

(1) the Maverick basin, where thick, massive deposits of fine-grained carbonate sediment accumulated below wave base; (2) the Devils River and Stuart City reef trends, where wave action was strong; and (3) the San Marcos platform-an area of tidal flats, sabkhas, and subareal erosion. Following deposition, the carbonate sediments on the San Marcos arch were subjected to subaerial erosion and karstification. In Late Cretaceous time, the rocks composing the Edwards aquifer were deeply buried by transgressive marine sediments.

Stratigraphically, the Edwards aquifer consists of the West Nueces, McKnight, and Salmon Peak Formations in the Maverick basin; the Devils River Limestone in the Devils River trend; and the Edwards Group and Georgetown Formation in the San Marcos platform. The top of the Edwards aquifer is designated as the base of the Del Rio Clay, and the base of the aquifer is designated as the top of the Glen Rose Limestone. The thickness of the aquifer ranges from 400 to $800 \mathrm{ft}$, with thickness increasing toward the west and south. The configurations of the top and base of the aquifer are complex because of the faulting. Along segments of some high-angle faults, the entire thickness of the aquifer is displaced vertically, and these fault segments act as barriers to downdip ground-water flow.

The porosity and permeability of the Edwards aquifer, which controls the capability of the aquifer to transmit water, is complex. It is dependent largely on the original texture of the carbonate rocks, the diagenetic processes that have occurred since deposition, and the locations of the confined and unconfined parts of the modern ground-water-flow system. Also, the permeability that developed in the freshwater part of the Edwards differs greatly from the permeability in the saline-water part. The small permeability of the salinewater part of the confined aquifer is attributed to the limited interconnection between pores in the rock matrix and to the lack of substantial dissolution along fractures. The large porosity and permeability of the freshwater part of the confined aquifer results primarily from dedolomitization (calcification) of dolomitic rocks by circulating calcium rich ground water. In the unconfined Edwards aquifer, the permeability is attributed to dissolution of limestone by circulating ground water, which led to the development of a cavernous network along vertical or inclined fractures.

The capability of the Edwards aquifer to transmit large quantities of water is indicated by the hundreds of large-capacity wells, many of which are capable of yielding more than $1,000 \mathrm{gal} / \mathrm{min}$. The large transmissive capability of the freshwater zone of the confined aquifer is indicated by the small hydraulic gradients, by the excellent correlation of water levels among widelyspaced wells, by the large spring discharges of more than several hundred cubic feet per second, and by the moderate variability of quality and temperature of water. Flowing wells that discharge more than 10,000 $\mathrm{gal} / \mathrm{min}$ have been drilled within the San Antonio city limits.

Estimates of the transmissivity of the aquifer within subareas of the San Antonio area were made on the basis of regional geology, hydrology, and hydrochemistry and tested in a digital model. On the basis of the simulation, the largest transmissivity is more than $4,300,000 \mathrm{ft}^{2} / \mathrm{d}$ in the freshwater zone of the aquifer in Comal County near Comal Springs, and the smallest transmissivity is $130 \mathrm{ft}^{2} / \mathrm{d}$ in the saline-water zone. The transmissivity throughout most of the freshwater zone of the confined aquifer ranges from 430,000 to $2,200,000 \mathrm{ft}^{2} / \mathrm{d}$. The transmissivity of the aquifer in the recharge area generally is less than $430,000 \mathrm{ft}^{2} / \mathrm{d}$. The maximum value of directional transmissivity is aligned along mapped faults. Simulated anisotropy ratios range from $0.0: 1$ to $1: 1$.

Other hydraulic characteristics are related to the unconfined and confined parts of the aquifer. Specific yield of the unconfined part ranges from 0.05 to 0.20 . The storage coefficient of the confined part is estimated 
to range from $1 \times 10^{-4}$ to $1 \times 10^{-5}$ depending on the thickness and porosity of the aquifer.

The climate of the San Antonio area influences hydrologic aspects of the aquifer. Average annual precipitation varies from about 21 in. in the western part of the area to about 34 in. in the eastern part and is responsible for replenishing the Edwards aquifer. However, periods of greater-than-average precipitation followed by extended droughts are characteristic of the region. The most severe drought recorded occurred during 1950-56, and this greatly impacted the aquifer. In recent years (middle 1970's to late 1980's), the area experienced greater-than-average precipitation.

The ground-water-flow system of the Edwards aquifer includes several components. These include a catchment area on the Edwards Plateau where the unconfined aquifer receives direct recharge, an intervening area of confining beds crossed by streams that drain the Edwards Plateau, a major recharge area paralleling the Balcones fault zone where streams lose flow directly into the unconfined and highly permeable Edwards aquifer, and the confined Edwards aquifer consisting of the freshwater and saline-water zones.

Water entering the Edwards aquifer in the Balcones fault zone moves downdip generally in a southeasterly direction from the unconfined to the confined parts of the aquifer. In the confined aquifer, flow occurs under low hydraulic gradients through fractured, highly transmissive, cavernous limestone toward the east and northeast and ultimately discharges at large springs and wells. The flowpaths are controlled laterally by barrier faults that locally compartmentalize the aquifer, especially in the eastern part of the San Antonio area. Simulation of the ground-water-flow system by a digital model indicated that these barrier faults channel flow toward major springs, thereby affecting spring discharge.

A small amount of freshwater crosses the downdip limit of the freshwater zone into the saline-water zone of the Edwards aquifer in the western part of the study area. Circulation in the saline-water zone of the Edwards aquifer is sluggish because of the much smaller transmissivity.

The recharge area for the Edwards aquifer is in the Balcones fault zone. Here the unconfined Edwards aquifer is recharged primarily by streamflow losses to the water table, which commonly lies more than $100 \mathrm{ft}$ below the streambeds and secondarily by direct infiltration of precipitation falling in the interstream areas. Streamflow losses occur principally along fractures, which might be solutionally enlarged, that traverse the area. All of the base flow and some of the storm runoff of streams crossing the recharge area infiltrate to the unconfined aquifer. The average annual recharge for 1934-88 was 635,500 acre-ft.

Water is discharged from the Edwards aquifer primarily from wells, springs, and seeps. A smaller discharge occurs as subsurface flow into the saline-water zone of the aquifer. Annual discharge generally has increased since the middle to late 1960's, and beginning in 1968, has consistently exceeded average annual recharge largely because well pumpage has doubled. However, total springflow also increased because of greater-than-average recharge during most years since the late 1960's.

Thousands of wells tap the Edwards aquifer in the San Antonio area. Wells in the confined aquifer can yield more than $1,000 \mathrm{gal} / \mathrm{min}$; however, wells in the unconfined aquifer typically yield less than 1,000 $\mathrm{gal} / \mathrm{min}$ because the saturated thickness and transmissivity generally are much less.

Springs and seeps account for nearly all natural discharge from the Edwards aquifer. The locations of major artesian springs are structurally controlled. The springs emerge from faults that intersect the aquifer and provide vertical pathways for water to rise to land surface at locations near structural constrictions.

The total volume of circulating freshwater in the Edwards aquifer is about 45 million acre-ft on the basis of an average saturated thickness of about $500 \mathrm{ft}$ in the confined part, $150 \mathrm{ft}$ in the unconfined part, and an average effective porosity of 6 percent. However, much of this water occurs at depths exceeding current economic limitations.

Long-term hydrographs of ground-water levels at San Antonio indicate no net decline during the 76year period from 1911 to 1987; from this, it can be concluded that there was no net loss of water in storage in the freshwater zone of the Edwards aquifer during that long-term period, assuming the San Antonio hydrograph represents the entire aquifer. Short-term waterlevel changes are attributed largely to substantial climatic changes and are manifest by severe declines during the drought of the late 1940's to middle 1950's and by rises to record highs during the abnormally wet years in the 1970's and 1980's. However, amplitudes of the water-level fluctuations within a given year are increasing mainly because of increased pumpage in Bexar County. 
During 55 years (1934-88) of pertinent hydrologic records, principal components of the groundwater budget (recharge, springflow, and pumpage) have varied greatly. Annual recharge varied from about 44,000 to 2,000,000 acre-ft, and annual springflow varied from about 70,000 to about 580,000 acre-ft. Annual pumpage increased from about 100,000 acre-ft in the 1930 's to more than 500,000 acre- $\mathrm{ft}$ periodically in the 1980's. However, the average annual recharge of 635,500 acre-ft is about equal to the sum of the average annual springflow of 359,500 acre- $\mathrm{ft}$ and average annual pumpage of 273,000 acre-ft, indicating no longterm decrease in ground-water storage because of springflow and pumpage.

\section{SELECTED REFERENCES}

Abbott, P.L., 1973, The Edwards Limestones in the Balcones fault zone, south-central Texas: Austin, Tex., University of Texas, unpub. Ph.D. thesis, 122 p.

Arnow, Ted, 1959, Ground-water geology of Bexar County, Texas: Texas Board of Water Engineers Bulletin 5911, $62 \mathrm{p}$.

Baker, E.T., Jr., Slade, R.M., Jr., Dorsey, M.E., Ruiz, L.M., and Duffin, G.L., 1986, Geohydrology of the Edwards aquifer in the Austin area, Texas: Texas Water Development Board Report 293, 215 p.

Barnes, V.E., Bell, W.C., Clabaugh, S.E., Cloud, P.E., Jr., McGehee, R.V., Rodda, P.U., and Young, K.P., 1972, Geology of the Llano region and Austin area: Austin, Tex., University of Texas, Bureau of Economic Geology Guidebook no. 13, 154 p.

Bennett, R.R., and Sayre, A.N., 1962, Geology and groundwater resources of Kinney County, Texas: Texas Water Commission Bulletin 6216, 176 p.

Bolden, G.P., 1983, Val Verde basin structural geology related to the rest of the Permian basin, in Structure and stratigraphy of the Val Verde basin-Devils River uplift, Texas: West Texas Geological Society Publication no. 83-77.

Bonnell, George, 1840, Topographical description of Texas: Austin, Tex., reprint by Texian Press.

Brune, Gunnar, 1975, Major and historical springs of Texas: Texas Water Development Board Report 189, 94 p.

Buffler, R.T., and Sawyer, D.S., 1985, Distribution of crust and early history, Gulf of Mexico basin: Gulf Coast Association of Geological Societies Transactions, v. 35, p. 333-344.

Burchett, C.R., Rettman, P.L., and Boning, C.W., 1986, The Edwards aquifer, extremely productive, but....a solesource water supply for San Antonio and surrounding counties in south-central Texas: Edwards Underground Water District Publication, 38 p.
Choquette, P.W., and Pray, L.C., 1970, Geologic nomenclature and classification of porosity in sedimentary carbonates: American Association of Petroleum Geologists Bulletin, v. 54, no. 2, p. 207-250.

Clement, T.J., and Sharp, J.M., Jr., 1988, Hydrochemical facies in the bad-water zone of the Edwards aquifer, central Texas, in Ground Water Geochemistry Conference Feb. 16-18, 1988: National Water Well Association, Dublin, Ohio, p. 127-149.

DeCook, K.J., 1963, Geology and ground-water resources of Hays County, Texas: U.S. Geological Survey WaterSupply Paper 1612, 72 p.

Dunham, R.J., 1962, Classification of carbonate rocks according to depositional texture, in Classification of Carbonate Rocks Symposium: American Association of Petroleum Geologists Memoir 1, p. 108-121.

Ellis, P.M., 1985, Diagenesis of the Lower Cretaceous Edwards Group in the Balcones fault zone area, south central Texas: Austin, Tex., The University of Texas, unpub. Ph.D dissertation, 228 p.

Fisher, W.L., and Rodda, P.U., 1969, Edwards Formation (Lower Cretaceous), Texas: Dolomitization in a carbonate platform system: American Association of Petroleum Geologists Bulletin, v. 53, no. 1, p. 55-72.

Flawn, P.T., Goldstein, A., Jr., King, P.B., and Weaver, C.E., 1961, The Ouachita System: Austin, Tex., University of Texas, Bureau of Economic Geology Publication 6120, $401 \mathrm{p}$.

Garza, Sergio, 1962, Recharge, discharge, and changes in ground-water storage in the Edwards and associated limestones, San Antonio area, Texas, a progress report on studies, 1955-59: Texas Board of Water Engineers Bulletin 6201, 51 p.

1966, Ground-water resources of the San Antonio area, Texas, a progress report on studies, 1960-64: Texas Water Development Board Report 34, 36 p.

1968, Aquifer characteristics from well-field production records, Edwards Limestone, San Antonio area, Texas: Tucson, Ariz., University of Arizona, M.S. thesis, $46 \mathrm{p}$.

George, W.O., 1952, Geology and ground-water resources of Comal County, Texas: U.S. Geological Survey WaterSupply Paper 1138, 126 p.

Hendy, W.J., 1957, Lower Cretaceous (Edwards), Caldwell and Guadalupe Counties, Texas: Gulf Coast Association of Geological Societies Transactions, v. 7, p. 23-34.

Hill, R.T., and Vaughn, T.W., 1898, Geology of the Edwards Plateau and Rio Grande Plain adjacent to Austin and San Antonio, Texas, with reference to the occurrence of underground waters: U.S. Geological Survey, 18th Annual Report, pt. II. 
Holt, C.L.R., Jr., 1959, Geology and ground-water resources of Medina County, Texas: U.S. Geological Survey Water-Supply Paper 1422, 213 p.

Horak, R.L., 1985, Trans-Pecos tectonism and its effect on the Permian basin, in Structure and tectonics of TransPecos, Texas: West Texas Geological Society.

Hunt, J.M., 1990, Generation and migration of petroleum from abnormally pressured fluid compartment: American Association of Petroleum Geologists, v. 74, no. 1, p. 1-11.

Klemt, W.B., Knowles, T.R., Elder, G.R., and Sieh, T.W., 1979, Ground-water resources and model applications for the Edwards (Balcones fault zone) aquifer in the San Antonio region, Texas: Texas Department of Water Resources Report 239, 88 p.

Land, L.F., Boning, C.W., Harmsen, Lynn, and Reeves, R.D., 1983, Streamflow losses along the Balcones fault zone, Nueces River basin, Texas: U.S. Geological Survey Water-Resources Investigations Report 83-4168, 72 p.

Longley, Glen, 1981, The Edwards aquifer: Earth's most diverse ground-water ecosystem: International Journal of Speleology, v. 11, p. 123-128.

Lowry, R.L., 1955, Recharge to Edwards ground-water reservoir: Consulting engineer's report to San Antonio City Water Board.

Lozo, F.E., and Smith, C.I., 1964, Revision of Comanche Cretaceous stratigraphic nomenclature, southern Edwards Plateau, southwest Texas: Gulf Coast Association of Geological Societies Transactions, v. 14, p. 285-307.

Maclay, R.W, and Land, L.F., 1988, Simulation of flow in the Edwards aquifer, San Antonio region, Texas, and refinement of storage and flow concepts: U.S. Geological Survey Water-Supply Paper 2336-A, 48 p.

Maclay, R.W., and Rettman, P.L., 1973, Regional specific yield of the Edwards and associated limestones in the San Antonio, Texas, area: Edwards Underground Water District report, $13 \mathrm{p}$.

Maclay, R.W., Rettman, P.L., and Small, T.A., 1980, Hydrochemical data for the Edwards aquifer in the San Antonio area, Texas: Texas Department of Water Resources LP-131, 38 p.

Maclay, R.W., and Small, T.A., 1976, Progress report on geology of the Edwards aquifer, San Antonio area, Texas, and preliminary interpretation of borehole geophysical and laboratory data on carbonate rocks: U.S. Geological Survey Open-File Report 76-627, 65 p.

1983, Hydrostratigraphic subdivisions and fault barriers of the Edwards aquifer, south-central Texas, USA, in Back, W., and LaMoreaux, P.E., eds., V.T. Stringfield Symposium, Processes in Karst Hydrology: Journal of Hydrology, v. 61, p. 127-146.
1984, Carbonate geology and hydrology of the Edwards aquifer in the San Antonio area, Texas: U.S. Geological Survey Open-File Report 83-537, 72 p.

Maclay, R.W., Small, T.A., and Rettman, P.L., 1980, Waterlevel, recharge, discharge, specific-capacity, well-yield, and aquifer-test data for the Edwards aquifer in the San Antonio area, Texas: Texas Department of Water Resources LP-133, 83 p.

1981, Application and analysis of borehole data for the Edwards aquifer in the San Antonio area, Texas: Texas Department of Water Resources LP-139, 88 p.

Mijatovic, B., 1968, A method of studying the hydrodynamic regime of karst aquifers by analysis of the discharge curve and level fluctuations during recession: Belgrade, Yugoslavia, Institute for Geological and Geophysical Research Bulletin, Series B, no. 8, p. 41-74.

Muehlberger, W.R., 1965, Late Paleozoic movement along the Texas lineament: New York Academy of Sciences Transactions, Series II, v. 27, no. 4, p. 385-392.

Nalley, G.M., 1989, Compilation of hydrologic data for the Edwards aquifer, San Antonio area, Texas, 1988, with 1934-88 summary: Edwards Underground Water District Bulletin 48, 157 p.

Office of State Climatologist, 1987, The climate of Texas counties: Austin, Tex., Natural Fibers Information Center of the Bureau of Business Research, University of Texas, Texas A\&M University, $567 \mathrm{p}$.

Pavlicek, Dianne, Small, T.A., and Rettman, P.L., 1987, Hydrogeologic data from a study of the freshwater zone/salinewater zone interface in the Edwards aquifer, San Antonio region, Texas: U.S. Geological Survey Open-File Report 87-389, 108 p.

Pearson, F.J., Jr., and Rettman, P.L., 1976, Geochemical and isotopic analyses of waters associated with the Edwards Limestone aquifer, central Texas: Edwards Underground Water District report, $35 \mathrm{p}$.

Pearson, F.J., Jr., Rettman, P.L., and Wyerman, T.A., 1975, Environmental tritium in the Edwards aquifer, central Texas, 1963-71: U.S. Geological Survey Open-File Report 74-362, $32 \mathrm{p}$.

Petitt, B.M., Jr., and George, W.O., 1956, Ground-water resources of the San Antonio area, Texas: Texas Board of Water Engineers Bulletin 5608, v. 1, 85 p.; v. 2, pt. 1, 255 p.; pt. 2, 288 p.; pt. 3, 231 p.

Puente, Celso, 1971, Records of precipitation, water levels, and ground-water recharge to the Edwards and associated limestones, San Antonio area, Texas, 1970: Edwards Underground Water District Bulletin 27, 11 p.

1972, Records of precipitation, water levels, and ground-water recharge to the Edwards and associated limestones, San Antonio area, Texas, 1971: Edwards Underground Water District Bulletin 30, 11 p. 
1973, Ground-water discharge from the Edwards and associated limestones, San Antonio area, Texas, 1972: Edwards Underground Water District Bulletin 31, 8 p.

1974, Records of precipitation, water levels, and ground-water recharge to the Edwards and associated limestones, San Antonio area, Texas, 1972-73:

Edwards Underground Water District Bulletin 33, 12 p.

1975, Relation of precipitation to annual groundwater recharge in the Edwards aquifer, San Antonio area, Texas: U.S. Geological Survey Open-File Report 75-298, $31 \mathrm{p}$.

1976, Statistical analysis of water-level, springflow, and streamflow data for the Edwards aquifer in southcentral Texas: U.S. Geological Survey Open-File Report 76-393, 58 p.

1978, Method of estimating natural recharge to the Edwards aquifer in the San Antonio area, Texas: U.S. Geological Survey Water-Resources Investigations Report 78-10, 34 p.

Reeves, R.D., and Ozuna, G.B., 1986, Compilation of hydrologic data for the Edwards aquifer, San Antonio area, Texas, 1983-84, with 1934-84 summary: Edwards Underground Water District Bulletin 43-44, 235 p.

Rettman, Paul, 1966, Records of precipitation, aquifer head, and ground-water recharge to the Edwards and associated limestones, San Antonio area, Texas, 1965:

Edwards Underground Water District Bulletin 12, 8 p.

1967, Records of precipitation, aquifer head, and ground-water recharge to the Edwards and associated limestones, San Antonio area, Texas, 1966: Edwards Underground Water District Bulletin 15, 9 p.

1968, Records of precipitation, aquifer head, and ground-water recharge to the Edwards and associated limestones, San Antonio area, Texas, 1967: Edwards Underground Water District Bulletin 18, 9 p.

1969, Records of precipitation, aquifer head, and ground-water recharge to the Edwards and associated limestones, San Antonio area, Texas, 1968: Edwards Underground Water District Bulletin 21, 9 p.

1970, Records of precipitation, water levels, and ground-water recharge to the Edwards and associated limestones, San Antonio area, Texas, 1969: Edwards Underground Water District Bulletin 24, $10 \mathrm{p}$.

Rose, P.R., 1972, Edwards Group, surface and subsurface, central Texas: Austin, Tex., University of Texas, Bureau of Economic Geology Report of Investigations 74, 198 p.

1986, Pipeline oil spills and the Edwards aquifers, central Texas, in Abbott, P.L., and Woodruff, C.M., Jr., eds., The Balcones escarpment-geology, hydrology, ecology and social development in central Texas: Geological Society of America, p. 163-183.
Salvador, Amos, 1987, Late Triassic-Jurassic paleogeography and origin of Gulf of Mexico basin: American Association of Petroleum Geologists Bulletin, v. 71, no. 4, p. 419-451.

Sams, R.H., 1983, Ouachita overthrust-a new look at old data: South Texas Geological Society Bulletin, v. 4, no. 8, April 1983.

Sayre, A.N., 1936, Geology and ground-water resources of Uvalde and Medina Counties, Texas: U.S. Geological Survey Water-Supply Paper 678, 146 p.

Sayre, A.N., and Bennett, R.R., 1942, Recharge, movement, and discharge in the Edwards Limestone reservoir, Texas: American Geophysics Union Transactions, pt. 1, p. 19-27.

Small, T.A., 1986, Hydrogeologic sections of the Edwards aquifer and its confining units in the San Antonio area, Texas: U.S. Geological Survey Water-Resources Investigations Report 85-4259, $52 \mathrm{p}$.

Small, T.A., and Maclay, R.W., 1982, Test-hole data for the Edwards aquifer in the San Antonio area, Texas: Texas Department of Water Resources LP-171, 153 p.

Smith, C.I., 1970, Lower Cretaceous stratigraphy, northern Coahuila, Mexico: Austin, Tex., University of Texas, Bureau of Economic Geology Report of Investigations $65,101 \mathrm{p}$.

1974, The Devils River trend and Maverick basin sequence, in Stratigraphy of the Edwards Group and equivalents, eastern Edwards Plateau: Guidebook for AAPG-SEPM Field Trip, March 1974, p. 14-18.

Taylor, T.U., 1902, Irrigation systems of Texas: U.S. Geological Survey Water-Supply Paper 71, $137 \mathrm{p}$.

Trescott, P.C., Pinder, G.F., and Larson, S.P., 1976, Finitedifference model for aquifer simulation in two dimensions with numerical experiments: U.S. Geological Survey Techniques of Water-Resources Investigations, book 7, chap. $\mathrm{C1}, 116 \mathrm{p}$.

Tucker, D.R., 1962, Subsurface Lower Cretaceous stratigraphy, central Texas, in Contributions to the geology of South Texas: San Antonio, Tex., South Texas Geological Society, p. 177-217.

University of Texas, Bureau of Economic Geology, 1974a, Geologic atlas of Texas, San Antonio sheet: Austin, Tex., scale 1:250,000.

1974b, Geologic atlas of Texas, Austin sheet: Austin, Tex., scale 1:250,000.

1974c, Geologic atlas of Texas, Seguin sheet: Austin, Tex., scale 1:250,000.

1977, Geologic atlas of Texas, Del Rio sheet: Austin, Tex., scale 1:250,000.

1978, Geologic atlas of Texas, Llano sheet: Austin, Tex., scale 1:250,000. 
U.S. Army Corps of Engineers, 1965, Survey report on Edwards underground reservoir, Guadalupe, San Antonio, and Nueces Rivers and tributaries, Texas, v. 1, Main report; v. 2, Project formulation: Fort Worth District, and San Antonio, Tex., Edwards Underground Water District.

Walper, J.L., and Miller R.E., 1985, Tectonic evolution of Gulf Coast basin, in Fourth Annual Research Conference, Gulf Coast Society of Economic Paleontologist and Mineralogist Foundation, June 1985, Proceedings: p. $25-41$.

Welder, F.A., and Reeves, R.D., 1962, Geology and groundwater resources of Uvalde County, Texas: Texas Water Commission Bulletin 6212, 263 p. (also published as U.S. Geological Survey Water-Supply Paper 1584, 49 p., 1964).

Wermund, E.G., Cepeda, J.C., and Luttrell, P.E., 1978, Regional distribution of fractures in the southern Edwards Plateau and their relationship to tectonics and caves: Austin, Tex., University of Texas, Bureau of Economic Geology Geological Circular 78-2, 14 p.

William F. Guyton and Associates, 1955, The Edwards Limestone reservoir, with a section on Recharge to the Edwards ground-water reservoir, by R.L. Lowry: Consulting engineer's report to San Antonio City Water Board for 1934-55.

1965, Report on recharge to the Edwards groundwater reservoir, 1962-63: Consulting gr.sund-water hydrologist's report to San Antonio City Water Board. 1979, Geohydrology of Comal, San Marcos, and Hueco Springs: Texas Department of Water Resources Report 234, 70 p.

Winter, J.A., 1962, Fredericksburg and Washita strata (subsurface Lower Cretaceous), southwest Texas, in Contributions to the geology of south Texas: San Antonio, Texas, South Texas Geological Society, p. 81-115.

Zoback, M.L., and Zoback, M., 1980, State of stress in the conterminous United States: Journal of Geophysical Research, v. 85, no. B11, p. 6,113-6,156. 
Table 1. Summary and description of the geologic units in the depositional provinces of the San Antonio area, Texas ${ }^{1}$

[Hydrologic function: $\mathrm{AQ}$, aquifer; $\mathrm{CU}$, confining unit]

\begin{tabular}{|c|c|c|c|c|c|c|c|c|c|}
\hline Erathem & Syotem & $\begin{array}{l}\text { Series or } \\
\text { provinciel } \\
\text { cerles }\end{array}$ & Group & Formation & $\begin{array}{l}\text { Hydrologis } \\
\text { function }\end{array}$ & $\begin{array}{l}\text { Momber or } \\
\text { Informal } \\
\text { unit }\end{array}$ & $\begin{array}{l}\text { Typlcal } \\
\text { thlck- } \\
\text { nees } \\
\text { (teet) }\end{array}$ & Lithology & $\begin{array}{l}\text { Depoeitional environment } \\
\text { and/or water-ylolding } \\
\text { characteriatics }\end{array}$ \\
\hline \multicolumn{10}{|c|}{ Maverick basin } \\
\hline Cenozoic & $\begin{array}{l}\text { Quaternary } \\
\text { and Tertiary }\end{array}$ & & & $\begin{array}{l}\text { Alluvial fan and } \\
\text { fluviatile } \\
\text { terrace } \\
\text { deposits }\end{array}$ & $\begin{array}{l}\text { AQ where } \\
\text { saturated }\end{array}$ & & 80 & $\begin{array}{l}\text { Gravel, sand, silt, and clay. } \\
\text { Coarser nearer the base } \\
\text { and toward the Balcones } \\
\text { escarpment. }\end{array}$ & $\begin{array}{l}\text { Alluvial fans extending } \\
\text { from the Balcones } \\
\text { escarpment. Associated } \\
\text { fluviatile deposits. }\end{array}$ \\
\hline \multirow[t]{13}{*}{ Mesozoic } & \multirow[t]{13}{*}{ Cretaceous } & \multirow[t]{4}{*}{ Gulfian } & Taylor & $\begin{array}{l}\text { Anacacho } \\
\text { Limestone }\end{array}$ & $\mathrm{CU}$ & & 500 & $\begin{array}{l}\text { Limestone and marl; } \\
\text { contains bentonite, chalky } \\
\text { and massive. }\end{array}$ & Little permeability. \\
\hline & & & Austin & Undivided & $\overline{C U}$ & & 600 & $\begin{array}{l}\text { Chalk and marl; chalk } \\
\text { mostly microgranular } \\
\text { calcite, bentonite seams, } \\
\text { glauconitic. }\end{array}$ & $\begin{array}{l}\text { Little to moderate } \\
\text { permeability. }\end{array}$ \\
\hline & & & & Igneous rocks & & & & Basalt. & $\begin{array}{l}\text { Intrusive sills, laccoliths, } \\
\text { and volcanic necks. } \\
\text { Negligible permeability. }\end{array}$ \\
\hline & & & Eagle Ford & Undivided & $\mathrm{CU}$ & & 250 & $\begin{array}{l}\text { Shale, siltstone, and } \\
\text { limestone; flaggy } \\
\text { limestone beds are } \\
\text { interbedded with } \\
\text { carbonaceous shale. }\end{array}$ & Little permeability. \\
\hline & & \multirow[t]{9}{*}{ Comanchean } & \multirow[t]{4}{*}{ Washita } & $\begin{array}{l}\text { Buda } \\
\text { Limestone }\end{array}$ & $\mathrm{CU}$ & & 100 & $\begin{array}{l}\text { Limestone; fine grained, } \\
\text { bioclastic, glauconitic, } \\
\text { hard, massive, nodular, } \\
\text { argillaceous toward top. }\end{array}$ & Little permeability. \\
\hline & & & & Del Rio Clay & $\mathbf{C U}$ & & 120 & $\begin{array}{l}\text { Clay and shale; calcareous } \\
\text { and gypsiferous, some } \\
\text { thin beds of siltstone. }\end{array}$ & Negligible permeability. \\
\hline & & & & $\begin{array}{l}\text { Salmon Peak } \\
\text { Formation }{ }^{2} \\
\text { (unit is } \\
\text { within the } \\
\text { Edwards } \\
\text { aquifer) }\end{array}$ & $\mathbf{A Q}$ & & 380 & $\begin{array}{l}\text { Upper } 80 \text { feet contains reef- } \\
\text { talus grainstone and } \\
\text { caprinid boundstone, } \\
\text { crossbedding of } \\
\text { grainstone; lower } 300 \text { feet } \\
\text { is uniform dense } \\
\text { carbonate mudstone. }\end{array}$ & $\begin{array}{l}\text { Deep-water deposits } \\
\text { except toward the top. } \\
\text { Upper part is moderately } \\
\text { to very permeable. Lower } \\
\text { part is almost } \\
\text { impermeable except } \\
\text { where fractured. }\end{array}$ \\
\hline & & & & \multirow[b]{2}{*}{$\begin{array}{l}\text { McKnight } \\
\text { Formation } \\
\text { (unit is } \\
\text { within the } \\
\text { Edwands } \\
\text { aquifer) }\end{array}$} & \multirow[t]{2}{*}{$\mathrm{CU}$} & & \multirow[t]{2}{*}{125} & \multirow[b]{2}{*}{$\begin{array}{l}\text { Upper } 45 \text { feet is shaley } \\
\text { limestone containing thin } \\
\text { zones of collapse breccia; } \\
\text { middle } 20 \text { feet is limey } \\
\text { mudstone; lower } 60 \text { feet } \\
\text { is grainstone and limey } \\
\text { mudstone containing } \\
\text { collapse breccia in upper } \\
\text { part. }\end{array}$} & \multirow[b]{2}{*}{$\begin{array}{l}\text { Deep-basin, euxinic } \\
\text { deposits. Little } \\
\text { permeability. }\end{array}$} \\
\hline & & & \multirow[t]{2}{*}{$\begin{array}{l}\text { Fredericks- } \\
\text { burg }\end{array}$} & & & & & & \\
\hline & & & & $\begin{array}{l}\text { West Nueces } \\
\text { Formation } 2 \\
\text { (unit is } \\
\text { within the } \\
\text { Edwards } \\
\text { aquifer) }\end{array}$ & $\mathrm{CU}$ & & 160 & $\begin{array}{l}\text { Upper } 90 \text { feet is largely a } \\
\text { massive unit of miliolid } \\
\text { and mollusk-bearing } \\
\text { grainstone; lower } 70 \text { feet } \\
\text { is nodular, dense } \\
\text { mudstone. }\end{array}$ & $\begin{array}{l}\text { Upper part is moderately } \\
\text { permeable. Lower part is } \\
\text { almost impermeable }\end{array}$ \\
\hline & & & \multirow[t]{3}{*}{ Trinity } & \multirow[t]{2}{*}{$\begin{array}{l}\text { Glen Rose } \\
\text { Limestone }\end{array}$} & \multirow[t]{2}{*}{$\mathbf{C U}$} & $\begin{array}{l}\text { Upper } \\
\text { member }\end{array}$ & \multirow[t]{2}{*}{$\begin{array}{r}1,000 \\
1,500\end{array}$} & $\begin{array}{l}\text { Limestone, dolomite, and } \\
\text { marl; limestone is fine } \\
\text { grained, hard to soft, } \\
\text { marly; dolomite is porous } \\
\text { and finely crystallized. }\end{array}$ & Little permeability. \\
\hline & & & & & & $\begin{array}{l}\text { Lower } \\
\text { member }\end{array}$ & & $\begin{array}{l}\text { Limestone and some marl. } \\
\text { Massive. }\end{array}$ & $\begin{array}{l}\text { More permeable towand } \\
\text { base of unit. }\end{array}$ \\
\hline & & & & $\begin{array}{l}\text { Pearsall } \\
\text { Formation }\end{array}$ & $\mathrm{CU}$ & & 400 & $\begin{array}{l}\text { Sandstone, limestone, and } \\
\text { shale. }\end{array}$ & Little permeability. \\
\hline
\end{tabular}

Footnotes at end of table. 
Table 1. Summary and description of the geologic units in the depositional provinces of the San Antonio area, Texas ${ }^{1}$ - Continued

\begin{tabular}{|c|c|c|c|c|c|c|c|c|c|}
\hline Erathem & Syatem & $\begin{array}{l}\text { Serlace or } \\
\text { provinelal } \\
\text { ecerles }\end{array}$ & Croup & Formation & $\begin{array}{l}\text { Hydrologle } \\
\text { hunction }\end{array}$ & $\begin{array}{l}\text { Momber or } \\
\text { informel } \\
\text { unit }\end{array}$ & $\begin{array}{l}\text { Typleal } \\
\text { thick- } \\
\text { neas } \\
\text { (toot) }\end{array}$ & Lithology & $\begin{array}{l}\text { Depoesitlonal environment } \\
\text { end/or water-yilelding } \\
\text { charecterietles }\end{array}$ \\
\hline \multicolumn{10}{|c|}{ Maverick basin - Continued } \\
\hline \multirow[t]{2}{*}{$\begin{array}{l}\text { Mesozoic- } \\
\text { Continued }\end{array}$} & \multirow[t]{2}{*}{$\begin{array}{c}\text { Cretaceous- } \\
\text { Continued }\end{array}$} & \multirow[t]{2}{*}{ Coahuilan } & & $\begin{array}{l}\text { Sligo } \\
\text { Pormation }\end{array}$ & $\mathrm{CU}$ & & 200 & Limestone and some shale. & $\begin{array}{l}\text { Little to moderate } \\
\text { permeability. }\end{array}$ \\
\hline & & & & $\begin{array}{l}\text { Hosston } \\
\text { Rormation }\end{array}$ & $\overline{C U}$ & & 900 & Sandstone and shale. & $\begin{array}{l}\text { Little to moderate } \\
\text { permeability. }\end{array}$ \\
\hline $\begin{array}{l}\text { Pre- } \\
\text { Mesozoic }\end{array}$ & $\begin{array}{l}\text { Pre- } \\
\text { Cretaceous }\end{array}$ & & & & & & & Sandstone and limestone. & Little permeability. \\
\hline \multicolumn{10}{|c|}{ Devils River trend } \\
\hline Cenozoic & Quaternary & & & $\begin{array}{l}\text { Alluvial and } \\
\text { terrace } \\
\text { deposits }\end{array}$ & $\begin{array}{l}\text { AQ where } \\
\text { saturated }\end{array}$ & & 40 & Gravel, sand, and silt. & $\begin{array}{l}\text { Unit occurs along major } \\
\text { stream courses. Deposits } \\
\text { are intermittently partly } \\
\text { saturated. Not an } \\
\text { important source of water } \\
\text { regionally. }\end{array}$ \\
\hline \multirow[t]{10}{*}{ Mesozoic } & \multirow[t]{10}{*}{ Cretaceous } & \multirow[t]{2}{*}{ Gulfian } & Austin & Undivided & $\overline{A Q}$ & & 200 & $\begin{array}{l}\text { Chalk, marl, and hard } \\
\text { limestone; mostly } \\
\text { mudstone. }\end{array}$ & $\begin{array}{l}\text { Moderate permeability in } \\
\text { places. }\end{array}$ \\
\hline & & & Eagle Ford & Undivided & $\mathrm{CU}$ & & 250 & Shale and flaggy limestone. & Little permeability. \\
\hline & & \multirow[t]{7}{*}{ Comanchean } & \multirow[t]{3}{*}{ Washita } & $\begin{array}{l}\text { Buda } \\
\text { Limestone }\end{array}$ & $\overline{C U}$ & & 50 & $\begin{array}{l}\text { Limestone; dense, micritic } \\
\text { limestone, and marly, } \\
\text { nodular limestone. }\end{array}$ & Little permeability. \\
\hline & & & & Del Rio Clay & $\mathrm{CU}$ & & 100 & \begin{tabular}{|l|} 
Shale and thin beds of \\
sandy limestone.
\end{tabular} & Little permeability. \\
\hline & & & & \multirow[b]{2}{*}{$\begin{array}{l}\text { Devils River } \\
\text { Limestone } \\
\text { (unit is } \\
\text { within the } \\
\text { Edwards } \\
\text { aquifer) }\end{array}$} & \multirow[t]{2}{*}{$\overline{A Q}$} & & \multirow[b]{2}{*}{$550-800$} & \multirow[b]{2}{*}{$\begin{array}{l}\text { Rudistic, shell-fragment } \\
\text { grainstone, wackestone, } \\
\text { mudstone and breccia; } \\
\text { wackestone and inudstone } \\
\text { locally burrowed, } \\
\text { rudistids common; } \\
\text { noctular, argillaceous } \\
\text { limestone toward the } \\
\text { base. }\end{array}$} & \multirow[b]{2}{*}{$\begin{array}{l}\text { Marine, tidal, and } \\
\text { supratidal unit. Exposed } \\
\text { in the Devils River trend. } \\
\text { Unit is a low barrier reef } \\
\text { that surrounded the } \\
\text { Maverick basin on the } \\
\text { north. Very permeable } \\
\text { and porous unit } \\
\text { particularly in the } \\
\text { middle and upper parts. } \\
\text { A major aquifer. }\end{array}$} \\
\hline & & & $\begin{array}{l}\text { Fredericks- } \\
\text { burg }\end{array}$ & & & & & & \\
\hline & & & \multirow[t]{3}{*}{ Trinity } & \multirow[t]{2}{*}{$\begin{array}{l}\text { Glen Rose } \\
\text { Limestone }\end{array}$} & \multirow[t]{2}{*}{$\overline{\mathrm{CU}}$} & \begin{tabular}{|l|} 
Upper \\
member
\end{tabular} & \multirow[t]{2}{*}{1,500} & Limestone and marl. & \multirow{2}{*}{$\begin{array}{l}\text { Negligible permeablity in } \\
\text { upper part and slightly to } \\
\text { moderately permeable in } \\
\text { the lower part. }\end{array}$} \\
\hline & & & & & & $\begin{array}{l}\text { Lower } \\
\text { member }\end{array}$ & & Massive limestone. & \\
\hline & & & & \begin{tabular}{|l|} 
Pearsall \\
Formation \\
\end{tabular} & $\mathrm{CU}$ & & 400 & $\begin{array}{l}\text { Sandstone, limestone, and } \\
\text { shale. }\end{array}$ & $\begin{array}{l}\text { Relatively impermeable } \\
\text { unit. }\end{array}$ \\
\hline & & Coahuilan & & $\begin{array}{l}\text { Sligo and } \\
\text { Hosston } \\
\text { Formations }\end{array}$ & CU & & $500-$ & $\begin{array}{l}\text { Limestone in upper part } \\
\text { and sandstone and shale } \\
\text { in lower part. }\end{array}$ & $\begin{array}{l}\text { Variable permeability. } \\
\text { Unit is relatively } \\
\text { impermeable overall. }\end{array}$ \\
\hline Paleozoic & \multicolumn{2}{|c|}{ Paleozoic rock } & & & & & & Sandstone, slate, and shale. & Relatively impermeable. \\
\hline \multicolumn{10}{|c|}{ San Marces platform in the Balcones fault zone } \\
\hline \multirow[t]{3}{*}{ Cenozoic } & \multirow[t]{2}{*}{ Quaternary } & & & Alluvium & $\mathrm{AQ}$ & & 45 & Silt, sand, gravel. & $\begin{array}{l}\text { Flood plain; aquifers in } \\
\text { hydraulic connoction } \\
\text { with streams. }\end{array}$ \\
\hline & & & & $\begin{array}{c}\text { Terrace } \\
\text { deposits }\end{array}$ & $\begin{array}{l}\text { Not } \\
\text { saturated }\end{array}$ & & 30 & $\begin{array}{l}\text { Coerse gravel, sand, and } \\
\text { silt. }\end{array}$ & $\begin{array}{l}\text { High terrace bordering } \\
\text { streams and surficial } \\
\text { deposits on high } \\
\text { interstream areas in } \\
\text { Balcones fault zone. }\end{array}$ \\
\hline & Tertiary & Eocene & Claibome & $\begin{array}{l}\text { Reklaw } \\
\text { Formation }\end{array}$ & $\overline{C U}$ & & 200 & $\begin{array}{l}\text { Sand, sandstone, and clay; } \\
\text { lignitic, friable to highly } \\
\text { indurated sandstone. }\end{array}$ & $\begin{array}{l}\text { Deltaic and swamp } \\
\text { deposits. Leaky confining } \\
\text { unit confines the Carrizo } \\
\text { aquifer below. }\end{array}$ \\
\hline
\end{tabular}

Footnotes at end of table. 
Table 1. Summary and description of the geologic units in the depositional provinces of the San Antonio area, Texas ${ }^{1}-$ Continued

\begin{tabular}{|c|c|c|c|c|c|c|c|c|c|}
\hline Erathem & Syetem & $\begin{array}{l}\text { Sarbes or } \\
\text { provincial } \\
\text { ecrice }\end{array}$ & Croup & Formation & $\begin{array}{l}\text { Aydrologle } \\
\text { tunction }\end{array}$ & $\begin{array}{l}\text { Momber or } \\
\text { informal } \\
\text { uniti }\end{array}$ & $\begin{array}{l}\text { Typleal } \\
\text { thick- } \\
\text { neses } \\
\text { (leet) }\end{array}$ & Lithology & $\begin{array}{l}\text { Depoelitionel environment } \\
\text { end/or water-ylelding } \\
\text { charnctertatice }\end{array}$ \\
\hline \multicolumn{10}{|c|}{ San Marcos platform in the Balcones fault zone-Continued } \\
\hline \multirow[t]{3}{*}{$\begin{array}{l}\text { Cenozoic- } \\
\text { Continued }\end{array}$} & \multirow[t]{3}{*}{$\begin{array}{l}\text { Tertiary- } \\
\text { Continued }\end{array}$} & $\begin{array}{l}\text { Eocene- } \\
\text { Continued }\end{array}$ & $\begin{array}{l}\text { Claiborno- } \\
\text { Continued }\end{array}$ & Carrizo Sand & AQ & & $200-800$ & $\begin{array}{l}\text { Sandstone; medium to very } \\
\text { coarse, friable, thick } \\
\text { bedded, few clay beds, } \\
\text { fernuginous. }\end{array}$ & $\begin{array}{l}\text { Very permeable aquifer } \\
\text { formed by deltaic and } \\
\text { shoreline deposits. }\end{array}$ \\
\hline & & \multirow[t]{2}{*}{$\begin{array}{r}\text { Eocene and } \\
\text { Paleocene }\end{array}$} & \multirow[t]{2}{*}{$\begin{array}{l}\text { Wilcox and } \\
\text { Midway }\end{array}$} & & \multirow[t]{2}{*}{$\overline{C U}$} & & 500 & $\begin{array}{l}\text { Clay, siltstone, and fine } \\
\text { grained sandstone; } \\
\text { lignitic, iron bearing. }\end{array}$ & \multirow[t]{2}{*}{$\begin{array}{l}\text { Leaky confining unit } \\
\text { formed by deltaic and } \\
\text { marine shoreline. }\end{array}$} \\
\hline & & & & & & Wills Point & 500 & Clay and sand. & \\
\hline \multirow[t]{10}{*}{ Mesozoic } & \multirow[t]{10}{*}{ Cretaceous } & \multirow[t]{5}{*}{ Gulfian } & Navarro & & CU & & 500 & \multirow{3}{*}{$\begin{array}{l}\text { Marl, clay, and sand in } \\
\text { upper part; chalky } \\
\text { limestone and marl in } \\
\text { lower part. }\end{array}$} & \multirow{3}{*}{$\begin{array}{l}\text { Deep-water marine } \\
\text { deposits. Major } \\
\text { restriction to vertical } \\
\text { cross-formational flow } \\
\text { separating Cretaceous } \\
\text { aquifer from Tertiary } \\
\text { aquifers. }\end{array}$} \\
\hline & & & \multirow[t]{2}{*}{ Taylor } & Pecan Gap & \multirow[t]{2}{*}{$\overline{C U}$} & & \multirow[t]{2}{*}{$300-500$} & & \\
\hline & & & & $\begin{array}{l}\text { Anacacho } \\
\text { Limestone }\end{array}$ & & & & & \\
\hline & & & Austin & Undivided & AQ & & $200-350$ & $\begin{array}{l}\text { Chalk, marl, and hard } \\
\text { limestone. Chalk is } \\
\text { largely a carbonate } \\
\text { mudstone. }\end{array}$ & $\begin{array}{l}\text { Minor aquifer that is } \\
\text { locally intenconnected } \\
\text { with the Edwards aquifer } \\
\text { by openings along some } \\
\text { faults. }\end{array}$ \\
\hline & & & Eagle Fond & Undivided & $\mathbf{C U}$ & & 50 & $\begin{array}{l}\text { Shale, siltstone, and } \\
\text { limestone; flaggy } \\
\text { limestone and shale in } \\
\text { upper part; siltstone and } \\
\text { very fine sandstone in } \\
\text { lower part. }\end{array}$ & $\begin{array}{l}\text { Restriction to vertical } \\
\text { cross-formational flow. }\end{array}$ \\
\hline & & \multirow[t]{5}{*}{ Comanchean } & \multirow[t]{2}{*}{ Washita } & $\begin{array}{l}\text { Buda } \\
\text { Limestone } \\
\text { and Del Rio } \\
\text { Clay }\end{array}$ & $\mathbf{C U}$ & & $100-200$ & $\begin{array}{l}\text { Dense, hard, nodular } \\
\text { limestone in upper part } \\
\text { and clay in lower pant. }\end{array}$ & $\begin{array}{l}\text { Fractured limestone in the } \\
\text { Buda Limestone locally } \\
\text { supplies small quantities } \\
\text { of water to wells. Del Rio } \\
\text { Clay has negligible } \\
\text { permeability. }\end{array}$ \\
\hline & & & & $\begin{array}{l}\text { Georgetown } \\
\text { Formation } \\
\text { (unit is } \\
\text { within the } \\
\text { Edwards } \\
\text { aquifer) }\end{array}$ & $\mathrm{CU}$ & & $20-60$ & $\begin{array}{l}\text { Dense, argillaceous } \\
\text { limestone; contains } \\
\text { pyrite. }\end{array}$ & $\begin{array}{l}\text { Deep-water limestone } \\
\text { with negligible porosity } \\
\text { and little permeability. }\end{array}$ \\
\hline & & & \multirow[t]{3}{*}{$\begin{array}{l}\text { Edwards (of } \\
\text { Rose, } \\
\text { 1972) }\end{array}$} & \multirow[t]{3}{*}{$\begin{array}{l}\text { Person } \\
\text { Formation } \\
\text { (unit is } \\
\text { within the } \\
\text { Edwards } \\
\text { aquifer) }\end{array}$} & \multirow[t]{3}{*}{ AQ } & $\begin{array}{l}\text { Cyclic and } \\
\text { marine } \\
\text { members, } \\
\text { undivided }\end{array}$ & 110 & $\begin{array}{l}\text { Limestone and dolomite; } \\
\text { limestone is } \\
\text { honeycombed and } \\
\text { interbedded with chalky, } \\
\text { porous limestone and } \\
\text { massive, recrystallized } \\
\text { limestone. }\end{array}$ & $\begin{array}{l}\text { Reefal carbonates } \\
\text { deposited under normal } \\
\text { marine conditions. } \\
\text { Zones with large porosity } \\
\text { and permeability are } \\
\text { laterally extensive. } \\
\text { Karstified unit. }\end{array}$ \\
\hline & & & & & & $\begin{array}{l}\text { Leached and } \\
\text { collapsed } \\
\text { members, } \\
\text { undivided }\end{array}$ & 70 & $\begin{array}{l}\text { Limestone and dolomite. } \\
\text { Recrystallized limestone } \\
\text { occurs predominantly in } \\
\text { the freshwater zone of the } \\
\text { aquifer. Dolomite occurs } \\
\text { in the saline-water zone. }\end{array}$ & $\begin{array}{l}\text { Tidal and supratidal } \\
\text { deposits; porous and } \\
\text { permeable beds of } \\
\text { collapse breccia and } \\
\text { burnowed biomicrites. } \\
\text { Zones of honeycombed } \\
\text { porosity are laterally } \\
\text { extensive. }\end{array}$ \\
\hline & & & & & & $\begin{array}{l}\text { Regional } \\
\text { dense } \\
\text { member }\end{array}$ & 20 & $\begin{array}{l}\text { Dense, carbonate } \\
\text { mudstone. }\end{array}$ & $\begin{array}{l}\text { Deep-water marine } \\
\text { deposit. Negligible } \\
\text { permeability and } \\
\text { porosity. Laterally } \\
\text { extensive bed that is a } \\
\text { restriction to vertical } \\
\text { flow in the aquifer. }\end{array}$ \\
\hline
\end{tabular}

Footnotes at end of table. 
Table 1. Summary and description of the geologic units in the depositional provinces of the San Antonio area, Texas ${ }^{1}-$ Continued

\begin{tabular}{|c|c|c|c|c|c|c|c|c|c|}
\hline Erathem & System & $\begin{array}{l}\text { Series or } \\
\text { provincial } \\
\text { ecrice }\end{array}$ & Group & Formation & $\begin{array}{l}\text { Hydrologle } \\
\text { function }\end{array}$ & $\begin{array}{l}\text { Inember or } \\
\text { informal } \\
\text { unit }\end{array}$ & $\begin{array}{l}\text { Typleal } \\
\text { thlck- } \\
\text { noes } \\
\text { (feet) }\end{array}$ & Lithology & $\begin{array}{l}\text { Depoeltional environment } \\
\text { end/or water-ylelding } \\
\text { cheracterlatics }\end{array}$ \\
\hline \multicolumn{10}{|c|}{ San Marcos platform in the Balcones fault zono-Continued } \\
\hline \multirow[t]{9}{*}{$\begin{array}{l}\text { Mesozoic- } \\
\text { Continued }\end{array}$} & \multirow[t]{9}{*}{$\begin{array}{l}\text { Cretaceous- } \\
\text { Continued }\end{array}$} & \multirow[t]{8}{*}{$\begin{array}{l}\text { Comanchean- } \\
\text { Continued }\end{array}$} & \multirow[t]{3}{*}{$\begin{array}{l}\text { Edwards (of } \\
\text { Rose, } \\
\text { 1972)- } \\
\text { Continued }\end{array}$} & \multirow[t]{3}{*}{$\begin{array}{l}\text { Kainer } \\
\text { Formation } \\
\text { (unit is } \\
\text { within the } \\
\text { Edwards } \\
\text { aquifer) }\end{array}$} & \multirow[t]{3}{*}{$\mathbf{A Q}$} & $\begin{array}{c}\text { Grainstone } \\
\text { member }\end{array}$ & 60 & $\begin{array}{l}\text { Hand, miliolid grainstone } \\
\text { and lesser beds of } \\
\text { mudstone and } \\
\text { wackestone. }\end{array}$ & $\begin{array}{l}\text { Shallow-water, lagoonal } \\
\text { sediments deposited in a } \\
\text { moderately high energy } \\
\text { environment. A cavern- } \\
\text { ous, honeycombed layer } \\
\text { commonly occurs near } \\
\text { the middle of the sub- } \\
\text { division. Interparticle } \\
\text { porosity is locally } \\
\text { effective. }\end{array}$ \\
\hline & & & & & & $\begin{array}{l}\text { Dolomitic } \\
\text { member } \\
\text { (includes } \\
\text { Kirschberg } \\
\text { evaporite) }\end{array}$ & 180 & $\begin{array}{l}\text { Dolomitized wackestone; } \\
\text { leached, evaporitic rocks } \\
\text { with breccia toward top; } \\
\text { dolomite occurs } \\
\text { principally in the saline } \\
\text { zone of the aquifer. }\end{array}$ & $\begin{array}{l}\text { Supratidal deposits towand } \\
\text { top. Mostly tidal to } \\
\text { subtidal deposits below. } \\
\text { Very ponous and } \\
\text { permeable zones formed } \\
\text { by hoxwork porosity in } \\
\text { breccia or by burrowed } \\
\text { zones. }\end{array}$ \\
\hline & & & & & & $\begin{array}{l}\text { Basal nodular } \\
\text { member }\end{array}$ & 60 & $\begin{array}{l}\text { Wackestone, dense, } \\
\text { nodular, stylolitic. }\end{array}$ & $\begin{array}{l}\text { Subtidal deposits. } \\
\text { Negligible porosity and } \\
\text { permeability. }\end{array}$ \\
\hline & & & \multirow[t]{5}{*}{ Trinity } & \multirow[t]{2}{*}{$\begin{array}{l}\text { Glen Rose } \\
\text { Limestone }\end{array}$} & \multirow[t]{2}{*}{$\mathbf{C U}$} & $\begin{array}{l}\text { Upper } \\
\text { member }\end{array}$ & $300-400$ & $\begin{array}{l}\text { Limestone, dolomite, } \\
\text { shale, and marl. } \\
\text { Alternating beds of } \\
\text { carbonates and maris. } \\
\text { Evaporite and dolomite } \\
\text { toward top, variable } \\
\text { bedding. }\end{array}$ & $\begin{array}{l}\text { Supratidal and shoreline } \\
\text { deposits toward top. } \\
\text { Tidal to subtidal deposits } \\
\text { below. Unit has little } \\
\text { vertical permeability but } \\
\text { has moderate lateral } \\
\text { permeability. }\end{array}$ \\
\hline & & & & & & $\begin{array}{l}\text { Lower } \\
\text { member }\end{array}$ & $200-250$ & $\begin{array}{l}\text { Massive limestone with a } \\
\text { few thin beds of marl. }\end{array}$ & $\begin{array}{l}\text { Marine deposits-caprinid } \\
\text { reef zones and porous } \\
\text { and permeable } \\
\text { honeycomb porosity } \\
\text { near the base. }\end{array}$ \\
\hline & & & & \multirow[t]{3}{*}{$\begin{array}{l}\text { Pearsall } \\
\text { Formation } \\
\text { (Travis Peak } \\
\text { Formation in } \\
\text { outcrop) }\end{array}$} & \multirow[t]{3}{*}{$\mathbf{C U}$} & $\begin{array}{l}\text { Bexar Shale } \\
\text { Member }\end{array}$ & \multirow[t]{3}{*}{300} & Limestone and shale. & $\begin{array}{l}\text { Shoreline deposits; } \\
\text { relatively impermeable } \\
\text { unit in the Balcones fault } \\
\text { zone. }\end{array}$ \\
\hline & & & & & & $\begin{array}{l}\text { Cow Creek } \\
\text { Limestone } \\
\text { Menber }\end{array}$ & & $\begin{array}{l}\text { Limestone and dolomite. } \\
\text { Grainstone, packstone, } \\
\text { and coquinoid beds. }\end{array}$ & $\begin{array}{l}\text { Moderately permeable } \\
\text { unit in Comal County. }\end{array}$ \\
\hline & & & & & & $\begin{array}{l}\text { Pine Island } \\
\text { Shale } \\
\text { Member }\end{array}$ & & $\begin{array}{l}\text { Shale and argillaceous } \\
\text { limestone. }\end{array}$ & Little permeability. \\
\hline & & Coahuilan & $\begin{array}{l}\text { Nuevo Leon } \\
\text { and } \\
\text { Durango } \\
\text { of Mexico }\end{array}$ & $\begin{array}{l}\text { Sligo and } \\
\text { Hosston } \\
\text { Formations }\end{array}$ & $\mathbf{C U}$ & & $\begin{array}{l}800- \\
1,500\end{array}$ & $\begin{array}{l}\text { Limestone, shale, and } \\
\text { sandstone. }\end{array}$ & $\begin{array}{l}\text { Sandstone in lower part is } \\
\text { moderately permeable. }\end{array}$ \\
\hline $\begin{array}{l}\text { Pre- } \\
\text { Mesozoic }\end{array}$ & $\begin{array}{l}\text { Pre- } \\
\text { Cretaceous }\end{array}$ & & & & & & & $\begin{array}{l}\text { Slate, phyllite, locally; } \\
\text { sedimentary rocks in } \\
\text { graben. }\end{array}$ & $\begin{array}{l}\text { Basement rocks. No } \\
\text { circulating ground water. }\end{array}$ \\
\hline
\end{tabular}

1 After Maclay and Small (1984).

${ }^{2}$ Lozo and Smith (1964). 